NASA CONTRACTOR REPORT
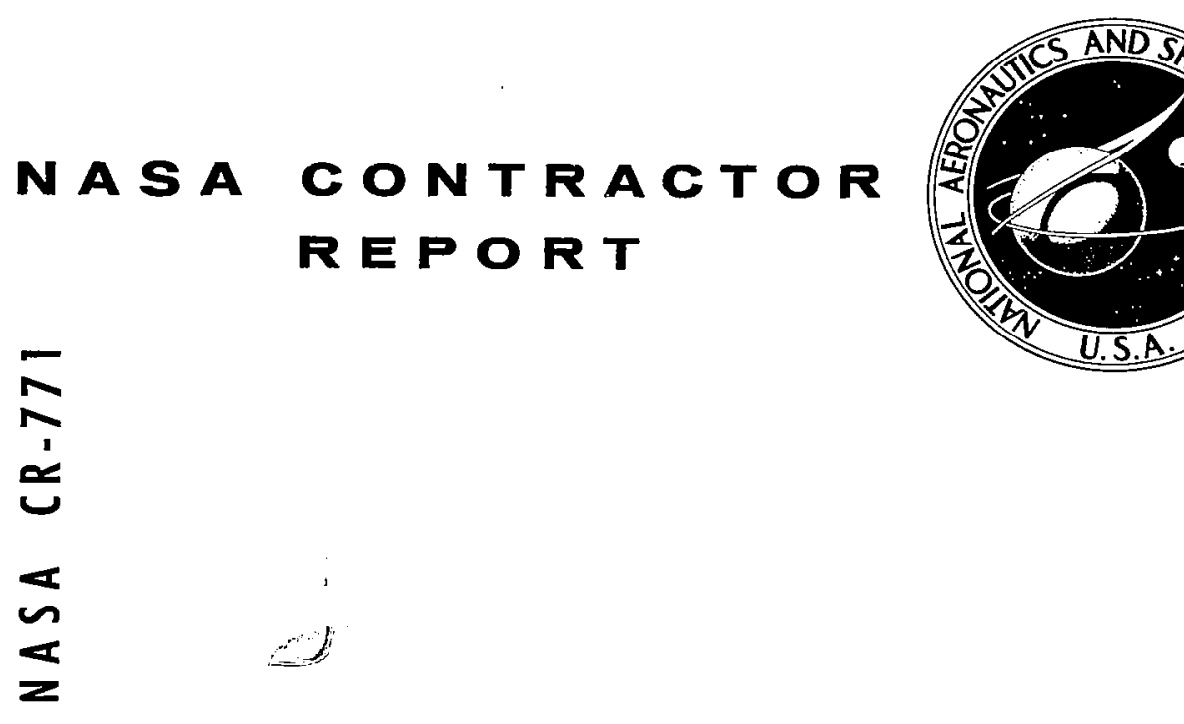

\title{
A WATER-VAPOR ELECTROLYSIS CELL WITH PHOSPHORIC ACID ELECTROLYTE
}

by J. E. Clifford, J. A. Gurklis, J. G. Beach, E. S. Kolic, E. W. Winter, A. C. Secrest, J. T. Gates, and C. L. Faust

Prepared by

BATTELLE MEMORIAL INSTITUTE

Columbus, Ohio

for Ames Research Center

national aeronautics and SPACE ADMINISTRATION - WASHINGTON, D. C. • JUNE 1967 
A WATER-VAPOR ELECTROLYSIS CELL

WITH PHOSPHORIC ACID ELECTROLYTE

By J. E. Clifford, J. A. Gurklis, J. G. Beach, E. S. Kolic, E. W. Winter, A. C. Secrest, J. T. Gates, and C. L. Faust

Distribution of this report is provided in the interest of information exchange. Responsibility for the contents resides in the author or organization that prepared it.

Prepared under Contract No. NAS 2-2156 by BATTELLE MEMORIAL INSTITUTE Columbus, Ohio

for Ames Research Center

NATIONAL AERONAUTICS AND SPACE ADMINISTRATION

For sale by the Clearinghouse for Federal Scientific and Technical Information Springfield, Virginia 22151 - CFSTI price $\$ 3.00$ 
- 
SUMMARY

INTRODUCTION

Prior Studies

Objectives.

Research Program

SYMBOLS

EXPERIMENTAL TECHNIQUES AND APPARATUS

10

Cell-Voltage Analysis . . . . . . . . . . . . . . 10

Introduction . . . . . . . . . . . . . . . . . 10

Definitions . . . . . . . . . . . . . . . . 10

Calculation of Decomposition Voltage . . . . . . . 11

Measurement of Polarization Components . . . . . 13

IR Polarization . . . . . . . . . . . . 13

Activation and Concentration Polarization . . . 13

Reference Electrodes . . . . . . . . . . . . 14

Autogenous Hydrogen Reference Electrode . . . 14

Palladium Alloy Reference Electrodes . . . . 15

Current-Inter ruption Technique . . . . . . . . . 15

Polarization-Decay Curves . . . . . . . . 15

Treatment of Oscilloscope-Trace Data . . . . 16

Current/Voltage-Curve Technique . . . . . . . . 17

Experimental Voltage-Analysis Cells . . . . . . . 22

Free-Liquid Cells (No Matrix) . . . . . . . 22

Matrix-Type Cells . . . . . . . . . . . 22

Liquid-Matrix Cell . . . . . . . . . . . 23

Vapor-Cell Construction . . . . . . . . . . . . . 23

Introduction . . . . . . . . . . . . . . . 23

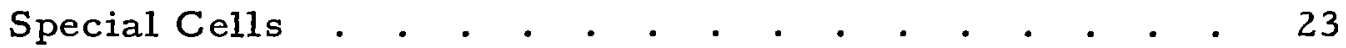

Cell I . . . . . . . . . . . . . . . 23

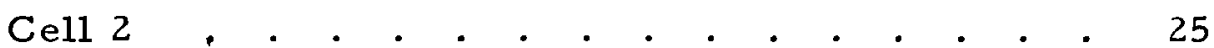

Experimental Cells . . . . . . . . . . . . . 25

Standard Features . . . . . . . . . . . . 25

Cell 3 . . . . . . . . . . . . . . . 26

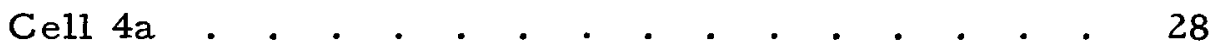

Cell $4 \mathrm{~b}$. 


\section{(Continued)}

$\underline{\text { Page }}$

Laboratory Model . . . . . . . . . . . . . 30

Extended Operational Testing . . . . . . . . . . . . . 33

Experimental Apparatus . . . . . . . . . . . 33

Gas Purity . . . . . . . . . . . . . . . . 34

Air Stream . . . . . . . . . . . . . .

Hydrogen Collection . . . . . . . . . . . . 36

EXPERIMENTAL DATA AND RESULTS . . . . . . . . . . . . . 37

Voltage-Analysis Results . . . . . . . . . . . . . 37

Measurement of Ohmic Polarization With

a Free Electrolyte . . . . . . . . . . . . . . 37

Voltage Analysis of Matrix-Type Cells . . . . . . 38

Identification of Polarization Components . . . 38

Free-Liquid and Liquid-Matrix Cell

Experiments and Results . . . . . . . . . . 42

Liquid-Matrix Cell . . . . . . . . . . 42

Free-Liquid Cell . . . . . . . . . . . 44

Effects of Phosphoric Acid Concentration and

Temperature on Cell Voltage . . . . . . . . . 45

Effects of Sulfuric Acid Concentration and

Temperature on Cell Voltage . . . . . . . . . 47

Extended Operational Testing Results . . . . . . . . 47

Electrochemical Reliability . . . . . . . . . . 47

Voltage-Analysis Results for Cells 2, 3, and 4b . . . 50

Current-Interruption Method . . . . . . 50

Current-Voltage Method . . . . . . . . . 52

Experimental Cell Performance . . . . . . . . 52

Cell l . . . . . . . . . . . . . . . 52

Cell 2 .

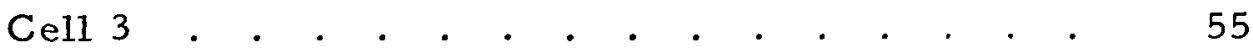

Cell 4b . . . . . . . . . . . . . . . . 56

Laboratory Model Performance. . . . . . . . . 59

Summary of 300-Hour Continuous
Operation Test... . . . . . . . . . 59

Voltage Characteristics . . . . . . . . . $\quad . \quad 59$

Series Operation of Cells in a Battery . . . . 62

Hydrogen Collection . . . . . . . . . . 63

Electrolyte Loss as Spray . . . . . . . . 63 
DISCUSSION OF VAPOR CELL DESIGN AND OPERATION $\quad \cdot \quad \cdot \quad \cdot \quad 64$

Correlation of Theory and Cell Operational Results . . . . 64 Introduction . . . . . . . . . . . . . . . . 64 Analysis of Laboratory Model Performance . . . . . 65

Fluid Dynamics . . . . . . . . . . . . 65

Heat Transfer . . . . . . . . . . . . 67

Mass Transfer. . . . . . . . . . . . . 68

Steady-State Electrolyte Concentration . . . . 69

Effect of Lower Current Density . . . . . . . 71

Analysis of Experimental Cell 4b Performance . . . . 72

Choice of Operating Conditions . . . . . . . . . 73

Integration for Cabin Air Conditioning . . . . . . . 74

Preferred Operating Conditions for Vapor Cell . . . . 76

CELL DESIGN CONCEPTS AND ENGINEERING ESTIMATES . . . 80

Cell Design for Operation on Cabin Air . . . . . . . . 80

Weight Reduction . . . . . . . . . . . . . . 80

New Cell Design Concept . . . . . . . . . . . 82

Proposed Prototype Design . . . . . . . . . . 82

Engineering Estimates for a Vapor Cell . . . . . . . . 85

Size, Weight, and Electrolysis Power . . . . . . . 85

Optimum Current Density . . . . . . . . . . . 87

Blower Power and Heat Rejection . . . . . . . . 88

Electrode Cost . . . . . . . . . . . . . . 89

Comparative Estimates . . . . . . . . . . . . . . 90

CONCLUSIONS • • •

RECOMMENDATIONS • • . . . . . • . . • • . . . . 92

\section{APPENDIX A}

DISCUSSION OF CIRCUITRY FOR OBTAINING POLARIZATIONDECAY CURVE . . . . . . . . . . . . . . . . 


\section{APPENDIX B}

$\underline{\text { Page }}$

AN ANALYSIS OF INITIAL ACID IMPREGNATION AND MATRIX

DESIGN IN RELATION TO FLOODING OF VAPOR CELLS .

APPENDIX C

DERIVATION OF THEORETICAL EQUATIONS DESCRIBING

VAPOR-CELL OPERATION . 


\section{A WATER-VAPOR ELECTROLYSIS CELL WITH PHOSPHORIC ACID ELECTROLYTE}

by

J. E. Clifford, J. A. Gurklis, J. G. Beach, E. S. Kolic, E. W. Winter, A. C. Secrest, J. T. Gates, and C. L. Faust

\section{SUMMARY}

A water-vapor electrolysis cell which uses a phosphoric acid electrolyte (commonly referred to as the " $\mathrm{P}_{2} \mathrm{O}_{5}$ cell") has been shown to be a potentially attractive subsystem for spacecraft atmosphere control on missions of extended duration. When the vapor cell is operated on recirculated cabin air, dehumidification and generation of oxygen occur simultaneously and many factors control the ultimate performance. A better understanding of the operation of the vapor cell has been obtained by further theoretical and experimental research directed toward the objectives of lower cell voltage and increased operational reliability.

Voltage analysis by a current-interruption technique was successfully applied to identification of the various components of polarization. The primary cause of the relatively high cell voltage with a vapor cell was identified as concentration polarization of which about 85 percent occurs at the anode. The concentration polarization was shown to be characteristic of the high acid concentrations required for operation of a vapor cell on the typical humidity of cabin air. Practically all of the activation polarization was eliminated by the use of platinized-platinum electrodes. Extended operational testing of experimental vapor cells showed that the platinized-platinum electrodes and electrolyte matrix were stable for at least 1000 hours with relatively constant cell voltage for constant operating conditions.

The voltage characteristics of a vapor cell as a function of current density are controlled by the steady-state concentration and temperature of the electrolyte in the matrix which determines the absolute value of the concentration polarization and ohmic polarization for a particular matrix design. The results of a theoretical analysis of fluid dynamics, heat transfer, mass transfer, and electrochemical factors that control the steady-state electrolyte concentration and temperature were consistent with the observed performance of experimental vapor cells. Equations for predicting cell performance were derived in terms of the independent design and operating variables. 
The above knowledge was applied to cell design with significant reduction in size and weight as exemplified in a small laboratory model unit consisting of a battery of ten cells in series. During the first 300 hours of continuous operation, the voltage characteristics were favorable and performance was as expected for the operating conditions used. Estimates for a prototype unit, weight optimized for a power-supply penalty of $300 \mathrm{lb} / \mathrm{kw}$ and based on extrapolation of the laboratory model performance are: 285 watts/ man at 2.25 volts $/ c e l l$ and $15 \mathrm{amp} / \mathrm{ft}^{2}$ for a cell sizc and weight of $0.12 \mathrm{ft}^{3} /$ man and $10 \mathrm{lb} / \mathrm{man}$.

The above estimates compare favorably with other water-electrolysis systems at the present state of the art and are enhanced by the indications of cell design simplicity and reliability for extended operation. Although not limited to use of water in cabin air, the vapor cell appears very attractive for ultimate integration in a cabin air-conditioning system because of unique advantages absent from other water-electrolysis methods for oxygen generation.

\section{INTRODUCTION}

\section{Prior Studies}

Prior research studies (ref. 1)* had indicated that the water-vapor electrolysis cell (often called the $\mathrm{P}_{2} \mathrm{O}_{5}$ cell) was technically feasible and promising. However, in comparison to other electrolysis methods of generating breathable oxygen, the vapor cell was not competitive because of the unusually high electrolysis voltage and lack of data on operational reliability.

The reason for using a phosphoric acid electrolyte (rather than a caus tic electrolyte) was the advantage of operation on carbon dioxide-containing air. Prior work and the present study have emphasized the use of the vapor cell on recycled cabin air where simultaneous dehumidification can be accomplished. Thus, the humidity of the air supplied to the cell is restricted to values typical of cabin air. Estimates from prior work at Battelle (ref. 1) based on operation of laboratory model cells indicated a cell voltage of 4.2 volts for a 3-man cell weight of 150 pounds. The possibility of some reduction in ccll voltage and cell weight was recognized. This was verified by concurrent studies by NASA which indicated a cell voltage of about 2 . 9 volts

* References are given at end of report. 
for a 3-man cell weight of 110 pounds. The power consumption was too high for a practical aerospace system in view of the high power penalties (i.e., $300 \mathrm{lb} / \mathrm{kw}$ based on current projected estimates for the time that oxygen recovery systems will be introduced); the large cell weight did not allow use of lower design current densities to reduce cell voltage.

Prior to the present study, the cause of the high cell voltage was not known with certainty. Part of the difficulty stemmed from lack of knowledge of the concentration of electrolyte in the matrix for various operating conditions. An extreme example is the misnomer of the phosphorus pentoxide $\left(\mathrm{P}_{2} \mathrm{O}_{5}\right)$ cell that derived from the very early belief that a semisolid electrolyte of hydrated $\mathrm{P}_{2} \mathrm{O}_{5}$ was necessary. Lack of control of input air properties and insufficient data at steady-state conditions were limitations evident from prior studies. Perhaps, the most important need was a theoretical basis for cell design and selection of cell operating conditions that would provide optimum cell performance at representative inlet air feed to the cell.

The prior studies defined the principal area for further research and influenced the initial research program.

\section{Objectives}

The overall objective of the present study was to advance the state of the art of the phosphoric acid-type water-vapor electrolysis cell. For the present study, the intended application was limited to cabin air.

The two specific objectives of the research program were:

(1) Reduction of cell voltage

(2) Increase in operational reliability.

\section{Research Program}

The research program was carried out as essentially four concurrent phases with different emphasis as the research progressed:

(1) Voltage analysis, to identify the problem, received the initial emphasis. 
(2) Extended operational testing of cells for at least 1000 hours was carried out primarily in support of electrochemical studies initially and for evaluation of cell design and operating performance as suitable cell designs evolved.

(3) Cell design improvement with primary emphasis on weight reduction was carried on throughout the program. Thus, some of the earlier experimental cells used for extended testing were not adequately sealed for separation and collection of hydrogen gas. This was recognized as primarily a design problem that did not adversely affect the electrochemical performance of the cells with respect to voltage analysis and evaluation of electrodes and matrix stability.

(4) Theoretical analysis of cell performance and derivation of design equations were taken up in the approximate order: electrochemistry, fluid dynamics, heat transfer, and mass transfer. The detailed derivations are covered in Appendixes $B$ and $C$ and examples are given of the use of the equations in analyzing experimental results. The most recent work on mass-transfer analysis provided the information needed for a complete picture of vapor-cell operation and allows estimates of expected performance under conditions not yet specifically evaluated in the continuing development program.

\section{SYMBOLS}

$a=$ constant in voltage equation

$A=$ area, $\mathrm{ft}^{2}$

$A_{d}=$ cross-sectional area of air channel $\left(W \times b^{\prime}\right), \mathrm{ft}^{2}$

$A_{e}=$ effective area of matrix $(L \times W)$, in. ${ }^{2}$

$A_{t}=$ total area of matrix, in. ${ }^{2}$

$\mathrm{b}=$ constant in voltage equation (slope)

$\mathrm{b}^{\top}=$ equivalent parallel plate spacing of air channel, mils 
$c=$ constant in voltage equation, ohm- $\mathrm{ft}^{2}$

$\mathrm{C}_{\mathrm{p}}=$ specific heat, Btu/lb-F

$D=$ diffusivity, $\mathrm{ft}^{2} / \mathrm{sec}$

$D_{e}=$ equivalent diameter of air flow duct, $f t$

$\mathrm{e}=$ initial acid impregnation, grams $\mathrm{P}_{2} \mathrm{O}_{5} /$ in. ${ }^{3}$ of the total matrix volume

$E=$ electrolysis cell voltage, volts

$E^{\prime}=$ cell voltage minus ohmic polarization $\left(E-E_{I R}\right)$, volts

$\mathrm{E}_{\mathrm{aa}}=$ activation polarization at anode, volts

$E_{\mathrm{ac}}=$ concentration polarization at anode, volts

$\mathrm{E}_{\mathrm{ca}}=$ activation polarization at $\mathrm{cathode}$, volts

$E_{c c}=$ concentration polarization at cathode, volts

$\mathrm{E}_{\mathrm{IR}}=$ ohmic polarization, volts

$E_{\mathrm{O}}=$ reversible cell potential, volts

$\mathrm{E}_{\mathrm{ov}}=$ total activation and concentration overvoltage $\left(E-E_{I R}-E_{O}\right)$, volts

$E_{t}=$ standard potential at temperature $T$, volts

$\mathrm{E}_{\mathrm{ta}}=$ total activation polarization (anode + cathode), volts

$E_{t c}=$ total concentraion polarization (anode + cathode), volts

$f=$ void fraction of matrix (porosity as a fraction)

$F=$ Faraday $(96,500 \mathrm{amp}-\mathrm{sec} /$ equivalent $)$

$\mathrm{h}=$ humidity, $\mathrm{lb} \mathrm{H}_{2} \mathrm{O} / \mathrm{lb} \mathrm{DA}$

$\mathrm{h}_{1}=$ humidity of air at inlet to vapor cell, $1 \mathrm{~b} \mathrm{H}_{2} \mathrm{O} / \mathrm{lb} \mathrm{DA}$

$\mathrm{h}_{2}=$ humidity of air at outlet of vapor cell, $1 \mathrm{~b} \mathrm{H}_{2} \mathrm{O} / \mathrm{lb} \mathrm{DA}$ 
$h_{a}=$ heat transfer coefficient, Btu/hr-ft ${ }^{2}-F$

$h_{\mathrm{av}}=$ average humidity from inlet to outlet, $1 \mathrm{~b} \mathrm{H} \mathrm{H}_{2} \mathrm{O} / \mathrm{lb} \mathrm{DA}$

$h_{D}=$ mass transfer coefficient, $\mathrm{ft}^{3} / \mathrm{hr}-\mathrm{ft}^{2}$

$\mathrm{h}_{\mathrm{e}}=$ water consumed by electrolysis, $1 \mathrm{~b} \mathrm{H}_{2} \mathrm{O} / 1 \mathrm{~b} \mathrm{DA}$

$\mathrm{h}_{\mathrm{e}}{ }^{\prime}=$ water added to air in cabin, $\mathrm{Ib}_{2} \mathrm{O} / \mathrm{lb} \mathrm{DA}$

$h_{h}=$ water in hydrogen leaving electrolysis cell, $1 \mathrm{~b} \mathrm{H}_{2} \mathrm{O} / \mathrm{lb} \mathrm{DA}$

$h_{h}{ }^{\prime}=$ water in hydrogen leaving electrolysis cell, $1 \mathrm{~b} \mathrm{H}_{2} \mathrm{O} / \mathrm{lb}$ dry $\mathrm{H}_{2}$

$h_{m}=$ humidity in equilibrium with electrolyte, $1 \mathrm{~b} \mathrm{H}_{2} \mathrm{O} / \mathrm{lb} \mathrm{DA}$

$\Delta \mathrm{h}_{\mathrm{m}}=$ average driving force vapor absorption, $1 \mathrm{~b} \mathrm{H}_{2} \mathrm{O} / \mathrm{lb} \mathrm{DA}$

$\Delta \mathrm{H}=$ heat of reaction, calories $/ \mathrm{g}-\mathrm{mol}$

$i=$ current density, $\operatorname{amp} / \mathrm{ft}^{2}$

$i^{*}=$ optimum current density for minimum system weight, $\mathrm{amp} / \mathrm{ft}^{2}$

$I=$ total current, amperes

$I^{\prime}=$ current per cell, amperes

$k=$ factor indicating added resistance of matrix

$\mathrm{k}^{\prime}=$ thermal conductivity, Btu/hr-ft ${ }^{2}-\mathrm{F}$

$\mathrm{K}=$ coefficient which is a function of heat transfer and masstransfer area

$\mathrm{K}_{1}=$ coefficient for heat (or mass) transfer from two walls

$\mathrm{K}_{2}=$ coefficient for heat (or mass) transfer from one wall

$\ell=$ distance through electrolyte from anode to cathode,, in.

$\mathrm{L}=$ length of matrix (electrode or air channel) in air flow direction, in.

$L_{p}=$ wetted perimeter of fluid flow channel, ft 
$L_{t}=$ total length of matrix in air flow direction, in.

$M=$ number of men (where one man consumes $2 \mathrm{lb} \mathrm{O}_{2} /$ day)

$n=$ relative air flow factor (ratio of water supplied by inlet air to water consumed by electrolysis)

$\mathrm{N}=$ number of electrons transferred in reaction

$N_{P r}=$ Prandtl number $\frac{C_{p} \mu}{k^{i}}$

$\mathrm{N}_{\mathrm{Re}}=$ Reynolds number $\frac{\mathrm{D}_{\mathrm{e}} \mathrm{V}}{\nu}$

$\mathrm{p}=$ vapor pressure of water, $\mathrm{mm} \mathrm{Hg}$

$\mathrm{P}_{\mathrm{H}_{2}}=$ partial pressure of hydrogen, atmospheres

$\mathrm{P}_{\mathrm{O}_{2}}=$ partial pressure of oxygen, atmospheres

$\mathrm{P}_{\mathrm{H}_{2} \mathrm{O}}=$ partial pressure of water vapor, atmospheres

$\mathrm{P}=$ total atmospheric pressure, $\mathrm{mm} \mathrm{Hg}$

$\Delta \mathrm{P}=$ pressure drop (wall friction) of air flow through cell, lb/in. ${ }^{2}$ (psi)

$\mathrm{P}_{\mathrm{e}}=$ power consumed in electrolysis, watts

$P_{f}=$ blower power (per cell) for cabin air recirculation, watts/cell

$\left(P_{f}\right)_{\text {total }}=$ total blower power $($ per man $)$, watts $/$ man

$P_{p}=$ electrical power penalty, watt $/ \mathrm{lb}$

$\mathrm{q}=$ volumetric air flow rate, $\mathrm{ft}^{3} / \mathrm{min}$

$q^{\prime}=$ volumetric air flow rate (per cell), $\mathrm{ft}^{3} / \mathrm{min}$ per cell

$\mathrm{q}_{T}=$ total volumetric air flow rate, $\mathrm{ft}^{3} / \mathrm{min}$

$Q=$ heat, watts 
$\mathrm{Q}_{\text {in }}=$ heat input to system from electrolysis, watts

$Q_{\text {out }}=$ heat output from system in air stream, watts

$R=$ gas constant

$\mathrm{R}_{\mathrm{H}}=$ hydraulic radius, $\mathrm{ft}$

$\mathrm{S}_{\mathrm{c}}=$ Schmidt number $\frac{\nu}{\mathrm{D}}$

$\mathrm{S}_{\mathrm{w}}=$ specific weight of cell per unit of electrode area, $1 \mathrm{~b} / \mathrm{ft}^{2}$

$S_{v}=$ specific volume of cell per unit of electrode area, $\mathrm{ft}^{3} / \mathrm{ft}^{2}$

$\mathrm{t}=$ thicknes $\mathrm{s}$ of matrix, in.

$t_{f}=$ fraction of available matrix porosity filled with electrolyte

$t_{x}=$ excess thickness of electrolyte beyond matrix thickness, in.

$t_{x}^{\prime}=$ optimum value of $t_{x}$, in.

$\mathrm{T}=$ temperature, $\mathrm{F}$

$\Delta T=$ difference in temperature in matrix $\left(T_{2}{ }^{\prime}-T_{1}{ }^{\prime}\right), F$

$\mathrm{T}_{1}=$ inlet air temperature, $\mathrm{F}$

$\mathrm{T}_{1}{ }^{\prime}=$ electrolyte temperature in matrix near inlet, $\mathrm{F}$

$\mathrm{T}_{2}=$ outlet air temperature, $\mathrm{F}$

$\mathrm{T}_{2}{ }^{\prime}=$ electrolyte temperature in matrix near outlet, $\mathrm{F}$

$\Delta \mathrm{T}_{\mathrm{A}}=$ temperature rise of air passing through cell $\left(\mathrm{T}_{2}-\mathrm{T}_{1}\right), \mathrm{F}$

$\Delta \mathrm{T}_{\mathrm{m}}=$ average temperature of electrolyte in matrix, $\mathrm{F}$

$\mathrm{v}=$ specific volume of moist inlet air, $\mathrm{ft}^{3} / \mathrm{lb}$

$\mathrm{V}=$ mean velocity of air flow through cell, $\mathrm{ft} / \mathrm{sec}$

$\mathrm{V}_{\mathrm{B}}=$ voltage of battery of cells in series, volts

$v_{e}=$ effective volume of matrix $\left(A_{e} t\right)$, in. ${ }^{3}$ 
$v_{t}=$ total volume of matrix $\left(A_{t} t\right)$, in. ${ }^{3}$

$w=$ wire size of screen electrode, in.

$\mathrm{w}_{\mathrm{H}_{2}} \mathrm{O}=$ weight rate of flow of water vapor, $1 \mathrm{~b} / \mathrm{hr}$

$\dot{w}_{i}=$ rate of water supply by inlet $\mathrm{air}, \mathrm{lb} / \mathrm{sec}$

$\dot{w}_{e}=$ rate of water consumption of electrolysis, $1 \mathrm{~b} / \mathrm{sec}$

$W=$ width of matrix (electrode or air channel) perpendicular to $L$ and parallel to electrode, in.

$\mathrm{w}_{\mathrm{b}}=$ weight penalty for blower power, $1 \mathrm{~b}$

$W_{h}=$ weight penalty for heat rejection, $1 \mathrm{~b}$

$\mathrm{W}_{t}=$ total width of matrix, in.

$\mathbf{x}=$ electrolyte volume factor, in. 3 electrolyte/gram $\mathrm{P}_{2} \mathrm{O}_{5}$

$x^{\prime}=$ electrolyte volume factor under steady-state conditions, in. 3 electrolyte/gram $\mathrm{P}_{2} \mathrm{O}_{5}$

$\eta=$ blower efficiency (as a fraction)

$\mu=$ viscosity of air, $\mathrm{lb} / \mathrm{ft}$ sec

$\mu^{\prime}=$ viscosity of air, centipoise

$\nu=$ kinematic viscosity of air, $\mathrm{ft}^{2} / \mathrm{sec}$

$\rho=$ specific resistance of electrolyte, ohm-in. 
Cell-Voltage Analysis

Introduction

To better understand the overall operation of the vapor cell and also to improve cell design and operating procedures, a quantitative knowledge of the various components of the total cell voltage was needed. Cell-voltage analysis, by use of a current-interruption method, to resolve the components of cell polarization provided the guidelines for subsequent research. The techniques and procedures used are described below. The significance of the data and results also are discussed.

Later in the research program, a current/voltage curve technique was used to supplement the current-interruption method of voltage analysis in the study of cell operation and performance.

\section{Definitions}

Let $E_{c e l l}$ be the observed voltage between the connecting terminals of the electrolysis cell for any given condition. Then,

$$
E_{c e l l}=\text { decomposition voltage }+ \text { total polarization voltages. }
$$

In this general relationship, the decomposition voltage can be obtained from independent thermodynamic data, as will be described later. It is considered separately because, as defined, the decomposition voltage is independent of current through the cell. The polarization voltages all depend upon electrode current densities.

Polarization is a generic term to include all voltages beyond the decomposition voltage. Polarization, as thus defined, includes all IR losses that arise from internal cell resistance between the terminals, in accordance with Ohm's law. Polarization includes also the voltages created by diffusion gradients of materials flowing into, out of, or through the cell. Sometimes the concentration or diffusion processes are referred to as "mass transfer". Finally, polarization includes the activation energies that are required to drive an irreversible electrochemical process at a given rate. 
Each of these polarization voltages may, in turn, be the sum of two or more voltages. Moreover, one or more polarization voltages may occur at each electrode, at both electrodes, or in the electrolyte. To bring some order into what is, or might be, a complicated situation, the following definitions are made for each type of voltage loss.

$$
\begin{aligned}
E_{I R}= & I R \text { (ohmic) polarization, the voltage loss due to ohmic re- } \\
& \text { sistance of the electrolyte or electrolyte media } \\
E_{a a}= & \text { Activation polarization at the anode } \\
E_{c a}= & \text { Activation polarization at the cathode } \\
E_{a c}= & \begin{array}{l}
\text { Polarization at the anode created by concentration (diffusion) } \\
\text { gradient at the anode }
\end{array} \\
E_{c c}= & \begin{aligned}
\text { Polarization at the cathode created by concentration (diffusion) } \\
\end{aligned}
\end{aligned}
$$

The summation of all these individual voltage losses is equal to total polarization.

If we now give the decomposition voltage a symbol $\mathrm{E}_{\mathrm{o}}$ the cell voltage can be written as follows:

$$
E_{c e l l}=E_{o}+E_{I R}+E_{a a}+E_{c a}+E_{a c}+E_{c c} \text {. }
$$

Sections of the report to follow will now give the details on how each of these defined polarization components were measured. Numerical values, measured in the laboratory, will be assigned to each of the parts of cell voltage.

\section{Calculation of Decomposition Voltage}

The decomposition voltage $\left(E_{0}\right)$ was calculated from the free-energy change at a temperature of $75 \mathrm{~F}$ for the reaction.

$$
\mathrm{H}_{2} \mathrm{O}(\mathrm{g}) \rightarrow \mathrm{H}_{2}(\mathrm{~g})+\frac{1}{2} \mathrm{O}_{2}(\mathrm{~g})
$$

To yield positive voltages to the calculated values, $E_{0}$ is considered to be the negative of the theoretical voltage that would ordinarily be calculated for the above reaction 


$$
E_{0}=-E_{t}+\frac{R T}{N F} \ln \frac{\left(p_{\mathrm{H}_{2}}\right)\left(p_{\mathrm{O}_{2}}\right)^{\frac{1}{2}}}{\left(\mathrm{p}_{\mathrm{H}_{2} \mathrm{O}}\right)}
$$

where

$$
\begin{aligned}
& E_{t}=\text { standard potential at temperature } T \text {, volts (using } \\
& \text { water in the gaseous state as standard permits } \\
& \text { direct use of the partial pressure of water over } \\
& \text { the acid as a measure of water activity) } \\
& \mathrm{P}_{\mathrm{H}_{2} \mathrm{O}}=\text { partial pressure of water vapor, atmospheres } \\
& \text { (assume vapor pressure of water over electrolyte } \\
& \text { for both cathode and anode compartments is the } \\
& \text { same) } \\
& \begin{array}{l}
\mathrm{p}_{\mathrm{H}_{2}}=\underset{\text { partial pressure of hydrogen in cathode compart- }}{\text { ment, atmospheres }}
\end{array} \\
& \mathrm{p}_{\mathrm{O}_{2}}=\text { partial pressure of oxygen in anode compartment, } \\
& T=\text { temperature on the Kelvin scale, } 297 \text { degrees } \\
& \mathrm{R}=\text { universal gas constant, } 8.314 \text { volt-coulombs per } \\
& \text { mole per degree } \\
& \mathrm{F}=\text { Faraday's constant, 96,500 coulombs per equivalent } \\
& \mathrm{N}=\text { number of equivalents per mole of decomposed water. }
\end{aligned}
$$

The standard potential at $75 \mathrm{~F},\left(E_{\mathrm{t}}\right)$, for reaction 1 is -1.184 volts. The minus voltage sign means that reaction 1 proceeds spontaneously in the opposite direction to that shown in the equation. The water-vapor pressure over an electrolyte of 85 percent $\mathrm{H}_{3} \mathrm{PO}_{4}$ is 0.0066 atmosphere. For a normal air mixture $\left(21 \% \mathrm{O}_{2}\right.$ and $\left.79 \% \mathrm{~N}_{2}\right)$ at a total pressure of 1 atmosphere in the anode compartment, $\mathrm{P}_{\mathrm{H}_{2} \mathrm{O}}=0.0066$ atmosphere and $\mathrm{PO}_{2}=0.209$ atmosphere. In the cathode compartment, assume only water vapor $\left(\mathrm{p}_{\mathrm{H}_{2} \mathrm{O}}=\right.$ $0.0066 \mathrm{~atm})$ and hydrogen $\left(\mathrm{P}_{\mathrm{H}_{2}}=0.99 \mathrm{~atm}\right)$. Equation 2 then becomes 


$$
\begin{aligned}
& E_{0}=1.184+\frac{(2.303)(8.314)(297)}{(2)(96,500)} \log \frac{(0.99)(0.209)^{\frac{1}{2}}}{(0.0066)} \\
& E_{0}=1.234 \text { volts. }
\end{aligned}
$$

The significance of this calculation is that all water-vapor electrolysis units, with the defined conditions, must operate at greater than 1.23 volts. Lesser voltages are theoretically impossible. Greater cell voltages are practically certain because total polarization, in practice, is always greater than zero. Moreover, changes in gas pressures will have minor effects on cell voltages. This follows because a tenfold change in $\mathrm{p}_{\mathrm{H}_{2}}, \mathrm{P}_{\mathrm{H}_{2} \mathrm{O}}$ or $\mathrm{PO}_{2}$ will change $E_{0}$ by less than 0.03 volt, or less than 3 percent.

Measurement of Polarization Components

IR Polarization. The basic principle used to measure resistance is to obtain the instantaneous voltage change when a cell at a given current, $I$, is changed to open circuit. Instantaneous in this situation was defined to mean within about 5-7 microseconds.

In the case of a liquid electrolyte, cell resistance was assumed to reside solely within the electrolyte solution. This resistance can sometimes be calculated using handbook values for specific resistance, $\rho$, with the relationship:

$$
\mathrm{R}=\rho \frac{\ell}{\mathrm{A}},
$$

where $\ell$ is the separation of the electrodes and $A$ is the electrode area. Multiplying the above equation by the current I, shows how IR voltage would be proportional to electrode current density, $i$ :

$$
\operatorname{IR}=\frac{\mathrm{I}}{\mathrm{A}} \rho \ell=\mathrm{i} \rho \ell
$$

Activation and Concentration Polarization. To measure activation voltages and voltages caused by concentration or mass transfer, the technique described by Trachtenberg (ref. 2) was adapted to the cell-voltage analysis. The assumption is made that diffusion processes are relatively 
slow and will requi re more than $10^{-4}$ second to show any measurable effect. Activation voltage changes are as sumed to be faster than diffusion polarization with major changes occurring between $10^{-6}$ and $10^{-4}$ second. Obviously, there will be an actual overiap of time with both voltage changes, but the above assumptions are believed to provide a meaningful separation of the effects for the first approximation.

To separate the effects at the anode from those at the cathode, a third electrode is required for reference purposes. A reference electrode is easily inserted into laboratory cells with liquid electrolyte. Insertion of a reference electrode into a matrix cell is more of a problem. Experimental details on reference electrodes will be described later.

\section{Reference Electrodes}

Autogenous Hydrogen Reference Electrode. The reference electrode used in the voltage-analysis studies was patterned closely to that described by Giner (ref. 3). This reference electrode is also called an autogenous hydrogen electrode. It consisted of a platinized-platinum wire spiral electrode at which hydrogen is evolved electrolytically at a cathode current density of about $1 \mathrm{ma} / \mathrm{sq} \mathrm{cm}$, another platinized-platinum wire spiral served as the anode. Both electrodes were enclosed in a fritted-glass gasdispersion tube. At the above current density, the overvoltage for hydrogen evolution is constant and amounts to less than about 20-30 millivolts for acid solutions of 1 to $5 \mathrm{~N}$, so that the potential practically equals the reversible hydrogen potential.

The autogenous hydrogen electrode was checked out and measured -43 millivolts with respect to a reversible hydrogen electrode in 85 percent phosphoric acid solution at $80 \mathrm{~F}$. For these measurements, two platinizedplatinum electrodes with pure hydrogen bubbling around them were used; these two hydrogen electrodes checked within 0.1 millivolt of each other, indicating good reliability.

For the work reported in figures 2 and 3 , the polarization-decay curves were plotted with the autogenous hydrogen electrode potential as zero.

This reference electrode was convenient to use for the initial cellvoltage analysis work. With the small experimental cell used, a tonguelike wick of microporous rubber matrix material extending from the cell proper to a beaker containing 85 percent $\mathrm{H}_{3} \mathrm{PO}_{4}$ solution served to make the conductivity bridge to the reference electrode, which was also immersed in the $\mathrm{H}_{3} \mathrm{PO}_{4}$ solution. 
Palladium Alloy Reference Electrodes. The autogenous hydrogen electrode, although suitable for some types of cell-voltage analysis work, was too cumbersome and not readily adapted for use with an operating vapor cell. For that reason, an effort was made to develop either a palladiumsilver $(75 \mathrm{Pd}-\mathrm{Ag})$ or pure palladium-foil hydrogen reference electrode.

Consistent and reliable readings with a hydrogen-charged 75 palladium-25 silver reference electrode versus the reversible hydrogen electrode could not be obtained. Work was then shifted to pure palladium in an effort to develop a stable and reliable alpha-palladium-hydrogen reference, somewhat similar to that described by Hoare (ref. 4).

Three palladium strips were inserted at different locations between the microporous rubber and the asbestos on the anode side of Cell 3 (see figure 4 shown later in report). A reliable method for charging the palladium electrodes with hydrogen in situ in the sealed electrolysis cell and for obtaining consistent and reliable electrode readings was not developed. The exact cause for variable reference-electrode readings is not known. Variable readings were probably associated with charging conditions (not knowing how much hydrogen is taken up by the palladium strip during charging), and also oxidizing conditions in the operating cell which cause potential decay.

For the above reasons, and because the cell-voltage analysis work had progressed sufficiently, so that knowledge of the individual electrode polarization components was not mandatory for interpreting cell performance, further work on developing a workable reference electrode inside the cell was recessed.

Current-Inter ruption Technique

Polarization-Decay Curves. The following procedure was used to obtain cell-voltage analysis data using the current-inter ruption technique. Data for determining total cell ohmic polarization and for plotting the individual polarization-decay curves for the anode and cathode electrodes versus a reference electrode were obtained as follows:

(1) Select a current density for cell operation and allow cell to operate until fairly steady readings of current and voltage are obtained (these conditions were obtained within 1-3 minutes). 
(2) Measure overall cell voltage, and also the potential of the working electrode versus the reference electrode. This latter potential was measured using either a Millivac or a vacuum-tube voltmeter; this potential serves as the reference basis for use with the oscilloscope traces.

(3) Interrupt current and visually observe or photograph the potential decay versus time traces on the oscilloscope.* A series of photographs (about 10-12), with different oscilloscope settings for sweep speed and vertical sensitivity, were taken to obtain data for the individual electrode curves (figures 8 and 9 shown later in the report).

(4) Plot data as shown in figure 8 (see illustrative examples handling data given later in the report).

A further discussion of the switching circuitry and also of the overall current interruption is presented in Appendix A.

Treatment of Oscilloscope-Trace Data. Two illustrative examples for getting data for polarization-decay curves (figure 8 shown later in report) from oscilloscope traces (see figure l) are given below:

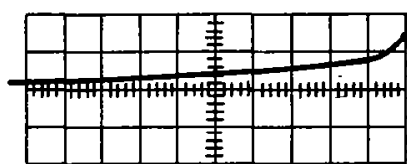

a.

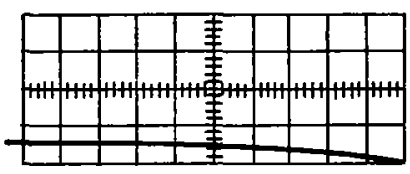

b.

A-51286

\section{FIGURE 1. OSCILLOSCOPE TRACES OF POLARIZATION DECAY}

See illustrative examples in text for additional information on the above oscilloscope traces.

\footnotetext{
*Type 545A Oscilloscope, Tektronix, Inc., Portland, Oregon. The technique employed was closely similar to that described by Isaac Trachtenberg (ref, 2). Current interruption in these studies was achieved using a manually operated switch which was hooked up with a mercury-wetted contact relay (Catalogue No. MW-1602-1, The Adams \& Westlake Co., Elkhart, Indiana).
} 
Example I: Anode Versus Reference-Electrode Data

(1) Anode versus autogenous hydrogen electrode potential = 2. 70 volts (measured with a vacuum-tube voltmeter)

(2) Data for oscilloscope trace of figure la:

Sweep speed (time $/ \mathrm{cm})=50 \mu \mathrm{sec} / \mathrm{cm}$

Vertical sensitivity $=0.2 \mathrm{volt} / \mathrm{cm}$

(3) Determination of value at $50-\mu$ sec time (point $A$ on figure 8)

Value from trace at $50-\mu \mathrm{sec}$ on figure $1 \mathrm{a}=0.24$ volt

Potential value for plotting: $2.70-0.24=2.46$ volts

(4) Determination of value at $100-\mu \mathrm{sec}$ time (point $B$ on figure 8)

Value from trace at $100 \mu \mathrm{sec}$ on figure $1 \mathrm{a}=0.27$ volt

Potential value for plotting: $2.70-0.27=2.43$ volts

Example II: Cathode Versus Reference-Electrode Data

(1) Cathode versus autogenous hydrogen electrode potential = -0.165 volt

(2) Data for oscilloscope trace of figure lb:

Sweep speed (time $/ \mathrm{cm}$ ) $=50 \mu \mathrm{sec} / \mathrm{cm}$

Vertical sensitivity $=0.2$ volts $/ \mathrm{cm}$

(3) Determination of value at $500 \mu \mathrm{sec}$ time (point $\mathrm{C}$ on figure 8)

Value from trace at extreme left of figure $1 \mathrm{~b}=0.133$ volt

Potential value for plotting $-0.165+0.133=-0.032$ volt

Current/Voltage-Curve Technique

Current/voltage curves can be used to describe the voltage characteristics of the electrolysis cell and are useful for cell design and optimization. Moreover, the curves appear to provide useful analytical information to supplement the voltage analysis by the current-interruption technique. Thus, some effort was devoted to perfecting the technique of obtaining current/voltage curves on the operating cells to develop a useful experimental "tool" for future studies.

\footnotetext{
"Figures 1a and 1b are tracings made from photograph of oscilloscope trace.
} 
The plot of cell voltage versus current density was obtained by decreasing the current in increments and reading the voltage on a digital voltmeter (current settings were read as accurately as possible from the ammeter).

Provided there is little change in concentration and temperature of the electrolyte in the matrix, the ohmic polarization will vary linearly with current density. Thus, a value of ohmic polarization $\left(E_{I R}\right)$ was assumed and the cell-voltage curve was corrected for ohmic polarization to give the curve of electrode polarization $\left(E^{\prime}=E-E_{I R}\right)$. By trial and error a value of ohmic resistance was obtained which gave a straight line for $E^{\prime}$. The trial-anderror method was used for data obtained with Cell 3 after 1074 hours of operation and shown later in figure 10.

The voltage characteristics of the cell can be described by an equation of the form:

$$
E=a+b \log i+c i,
$$

which relates cell voltage and current density. (It is important to note that the equation relates only to the average steady-state electrolyte concentration and temperature that existed in the matrix at the steady-state current density immediately prior to obtaining the current/voltage curve.)

Using the assumption (verified several times by careful measurements) that $E-E_{I R}$ is a straight line when plotted on semilog paper versus log current density, a simple procedure was worked out for determining the voltage equation from three voltage measurements that can be obtained quickly:

$E_{1}$ at $32.8 \mathrm{amp} / \mathrm{ft}^{2}$ (the operating current density for experimental
cells) $\mathrm{E}_{2}$ at $10 \mathrm{amp} / \mathrm{ft}^{2}$ $\mathrm{E}_{3}$ at $1 \mathrm{amp} / \mathrm{ft}^{2}$.

The three voltages are sufficient to determine the constants by simultaneous solution of three equations of the form:

$$
E=a+b \log i+c i
$$

The choice of current densities provides a simplification since $i_{2}=10$ and $\log i_{2}=1 ; i_{3}=1$ and $\log i_{3}=0$. Therefore 


$$
\begin{aligned}
& c=\frac{E_{1}+0.516 E_{3}-1.516 E_{2}}{18.16} \\
& a=E_{3}-c \\
& b=E_{2}-a-10 c .
\end{aligned}
$$

The preferred technique requires only three rapid voltage measurements ( $\sim 30$ seconds) starting with the operating current $\left(32.8 \mathrm{amp} / \mathrm{ft}^{2}\right.$ for the experimental cells). Slight differences in the value of the constants were obtained depending on whether the voltages corresponded to decreasing the current density $(<i)$ or increasing the current density $(>i)$. The sequence of current densities used was $32.8,10,1,10$, and $32.8 \mathrm{amp} / \mathrm{ft}^{2}$. Thus, the values obtained in the increasing-current-density half of the cycle involve a time delay and more departure from steady-state conditions. There appears to be more difference in the constants depending on whether the air flow was on or off as shown by the following comparative results for Cell $4 \mathrm{~b}$ at 287 hours of operation:

$$
\begin{array}{ll}
E=a+b \log i+c i \\
E=1.956+0.130 \log i+0.0094 i & \text { (air flow off, <i) } \\
E=1.956+0.138 \log i+0.0095 i & \text { (air flow off, >i) } \\
E=1.945+0.121 \log i+0.0104 i & \text { (air flow on, }<i) \\
E=1.945+0.126 \log i+0.0098 i & \text { (air flow on, }>i) .
\end{array}
$$

The constant $\mathrm{c}$ is probably a good indicator of the average steady-state electrolyte concentration/temperature as reflected in the specific resistance $\rho$ :

$$
\begin{aligned}
& c i=\frac{\rho I t k}{144 \mathrm{~A}}=\frac{\rho \mathrm{i} \mathrm{k}}{144} \\
& c=\frac{t \mathrm{k} \rho}{144} \\
& \rho=\frac{144 \mathrm{c}}{t \mathrm{k}},
\end{aligned}
$$


where

$$
\begin{aligned}
& c=\text { constant in cell voltage equation, ohm } / \mathrm{ft}^{2} \\
& t=\text { thicknes of matrix, inch } \\
& k=\text { factor indicating added resistance of matrix } \\
& \rho=\text { specific resistance of electrolyte, ohm-inches } \\
& I=\text { current, amperes } \\
& A=\text { area, } \mathrm{ft}^{2} \\
& i=\text { current density, } \mathrm{amp} / \mathrm{ft}^{2} .
\end{aligned}
$$

Values of specific resistance $(\rho)$ for phosphoric acid as a function of temperature and concentration are shown in figure 2.

The value of $k$ is not known accurately but measurements of ohmic polarization of phosphoric acid solutions with and without a 0.033 -inch microporous rubber matrix suggest a value of $\mathrm{k} \cong 8$. Thus, for the experimental cells which also contained two 0.010-inch-asbestos layers, an estimate is that $\mathrm{k} \cong 9$.

$$
\rho=\frac{144 c}{(0.053)(9)}=300 \mathrm{c} .
$$

Using a value of $c=0.0094$ (from the voltage equations shown above), $\rho$ is calculated to be $2.8 \mathrm{ohm}$-inches. As can be seen from figure 2 , there are many combinations of temperature and acid concentration for which $\rho=$ $2.8 \mathrm{ohm}$-inches. However, the range of possible values of electrolyte concentration and temperature is narrowed as a first approximation. For more precise estimates, one other item of knowledge is needed, such as the steady-state electrolyte temperature of about $90 \mathrm{~F}$ or the acid concentration of about 76 percent $\mathrm{H}_{3} \mathrm{PO}_{4}$. The latter information was developed from theoretical analysis of heat transfer and mass transfer to be discussed in more detail later in this report. Primarily, the value of $c$ determined from current/voltage curves was used as a cross check on other estimates of the steady-state electrolyte.

The constant "a" in the equation is the voltage at $1 \mathrm{amp} / \mathrm{ft}^{2}$ corrected for $E_{I R}$. Since the activation polarization $E_{t a}$ is probably negligible at this low current density, $(a-1.23)$ is approximately equal to the total concentration polarization $E_{\text {tc }}$ at $1 \mathrm{amp} / \mathrm{ft}^{2}$. Thus, it is probable that the constants 


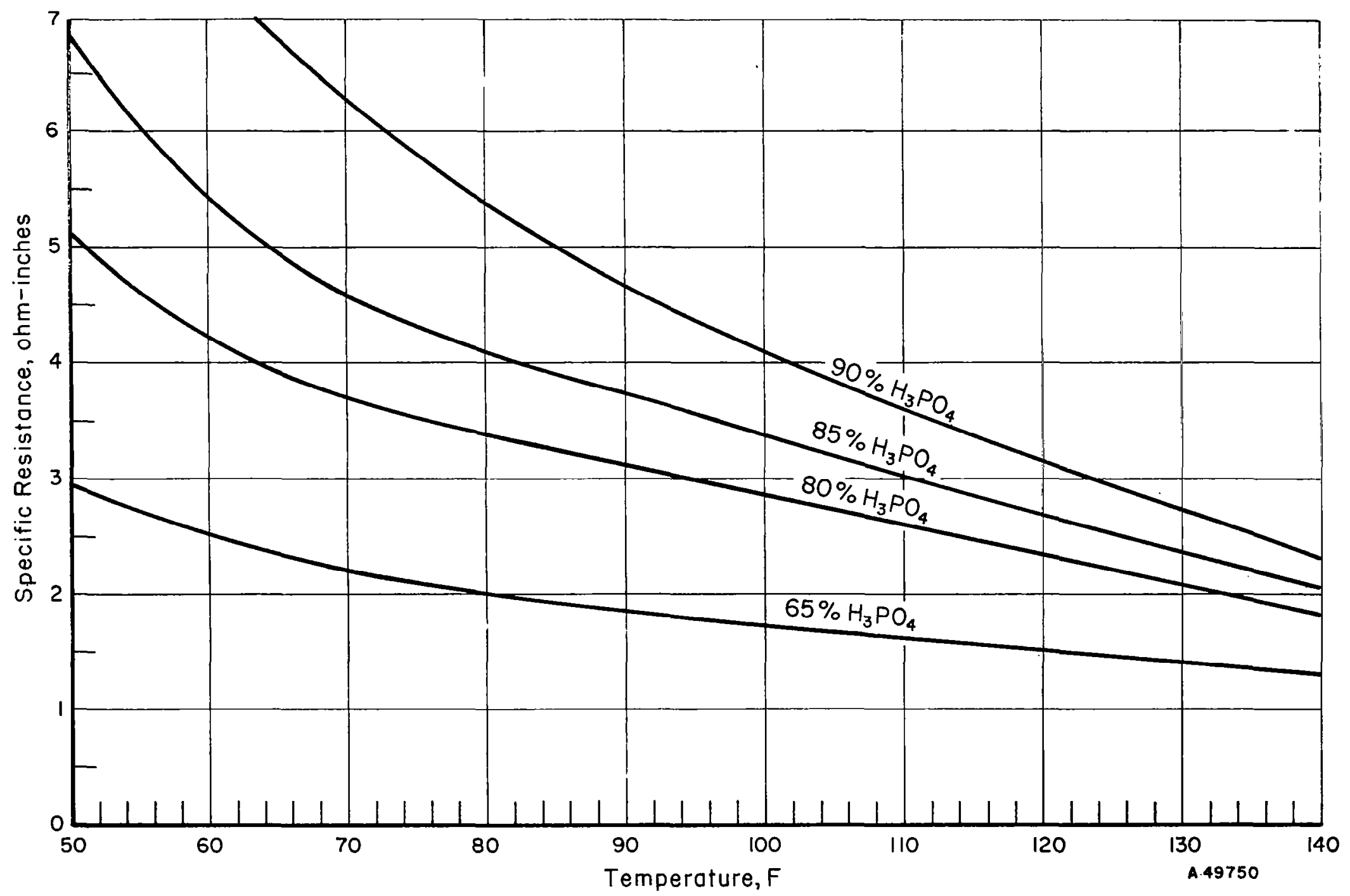

FIGURE 2. SPECIFIC RESISTANCE OF PHOSPHORIC ACID SOLUTIONS AS A FUNCTION OF TEMPERATURE FOR VARIOUS CONCENTRATIONS 
$a$ and $b$ (the slope of the straight line) are functions of the electrolyte concentration and temperature and reflect the effect of changes in these variables on the total concentration polarization. The effect of electrolyte concentration and temperature on the constant "a" was determined in studies with a free electrolyte using the current-voltage technique (table 4 shown later in this report).

\section{Experimental Voltage-Analysis Cells}

To denote experimental cells that were constructed specifically for purposes of developing the voltage-analysis techniques and for carrying out voltage-analysis studies, the notation VA is used. The various types of VA cells employed are described below.

Free-Liquid Cells (No Matrix). To check on the ability of the currentinter ruption method to show changes in ohmic polarization $\left(E_{I R}\right)$ with current density, a small rectangular glass cell, VA-1 (Voltage Analysis Cell 1) was used. The cell contained no matrix and was filled with 85 percent $\mathrm{H}_{3} \mathrm{PO}_{4}$ solution. Smooth platinum sheet electrodes (immersed area 1 by $l$ inch) were used. The back sides of the electrodes were stopped off with an organic coating; the anode-to-cathode spacing was 1 inch.

Slight modifications of free-liquid cell VA-1 were made for carrying out other voltage-analysis studies. In Cell VA-la, a gentle stirring of the electrolyte was provided with a magnetic bar; an autogenous hydrogen electrode was also used in Cell VA-1a. In Cell VA-1b, which was used to study the effects of acid concentration and temperature on cell voltage components by means of the current/voltage curve technique, the autogenous hydrogen electrode was omitted; the stirring bar was used.

Matrix-Type Cells. Following the ohmic-polarization studies on the small glass cell with a liquid electrolyte, several small experimental cells VA-2a and VA-2b with flat microporous rubber matrixes, ${ }^{*}$ impregnated with 85 percent $\mathrm{H}_{3} \mathrm{PO}_{4}$ electrolyte, were assembled for use in carrying out complete cell-voltage analysis studies. Platinum electrodes (45-mesh, 0.078inch-diameter wire) were used: bright platinum (VA-2a) and platinized platinum (VA-2b). The cell area was 0.8 in. $^{2}$; no air circulation was employed.

* ACE-SIL flat microporous battery separator, American Hard Rubber Co., Akron, Ohio. 
Liquid-Matrix Cell. To simulate a cell with gas evolved to a gas phase, and one in which gas intermixing was prevented, the liquid matrix cell assembly, VA-3, shown in figure 3 was designed. A platinizedplatinum screen and asbestos-sheet matrix were attached to one end of each of two vertical glass tubes. These two tubes were positioned with the screen electrodes touching the liquid at the solution level. The tubes were spaced on 6-inch centers. Electrolysis was carried out in 85 percent $\mathrm{H}_{3} \mathrm{PO}_{4}$ at a temperature of 85-90 F. An autogenous hydrogen reference electrode was used for voltage analysis by the current-interruption technique.

\section{Vapor-Cell Construction}

Introduction

The water-vapor electrolysis cells discussed in this section were used in the extended operational testing program. The construction of the cells is described in detail sufficient for interpretation of experimental results relating to materials used and stability for continuous extended operation. Comparative evaluation of materials was not an objective of the present study. All of the functional design improvements evaluated in successive experimental cells were incorporated in the ten identical experimental cells used in the laboratory model. The technique of construction and assembly of the laboratory model is described in more detail.

Comparative data on cell component weights are listed in table 9 which appears later in this report. Comparative data on initial acid impregnation of experimental vapor cells is shown in table B-1, Appendix B.

Special Cells

Cell 1. The cell unit obtained from NASA was selected for the first evaluation to provide a base line and tie-in with prior studies. The only modification of the cell was the addition of a 5-mil sheet of split asbestos (supplied by NASA) to each side of the "as-received" matrix. The electrodes were replatinized. The matrix ( 9 by 3 inches) was impregnated with 21 grams of 96 percent $\mathrm{H}_{3} \mathrm{PO}_{4}\left(70\right.$ percent $\left.\mathrm{P}_{2} \mathrm{O}_{5}\right)$. Other details of cell construction are not pertinent in view of the limited evaluation of this cell. 


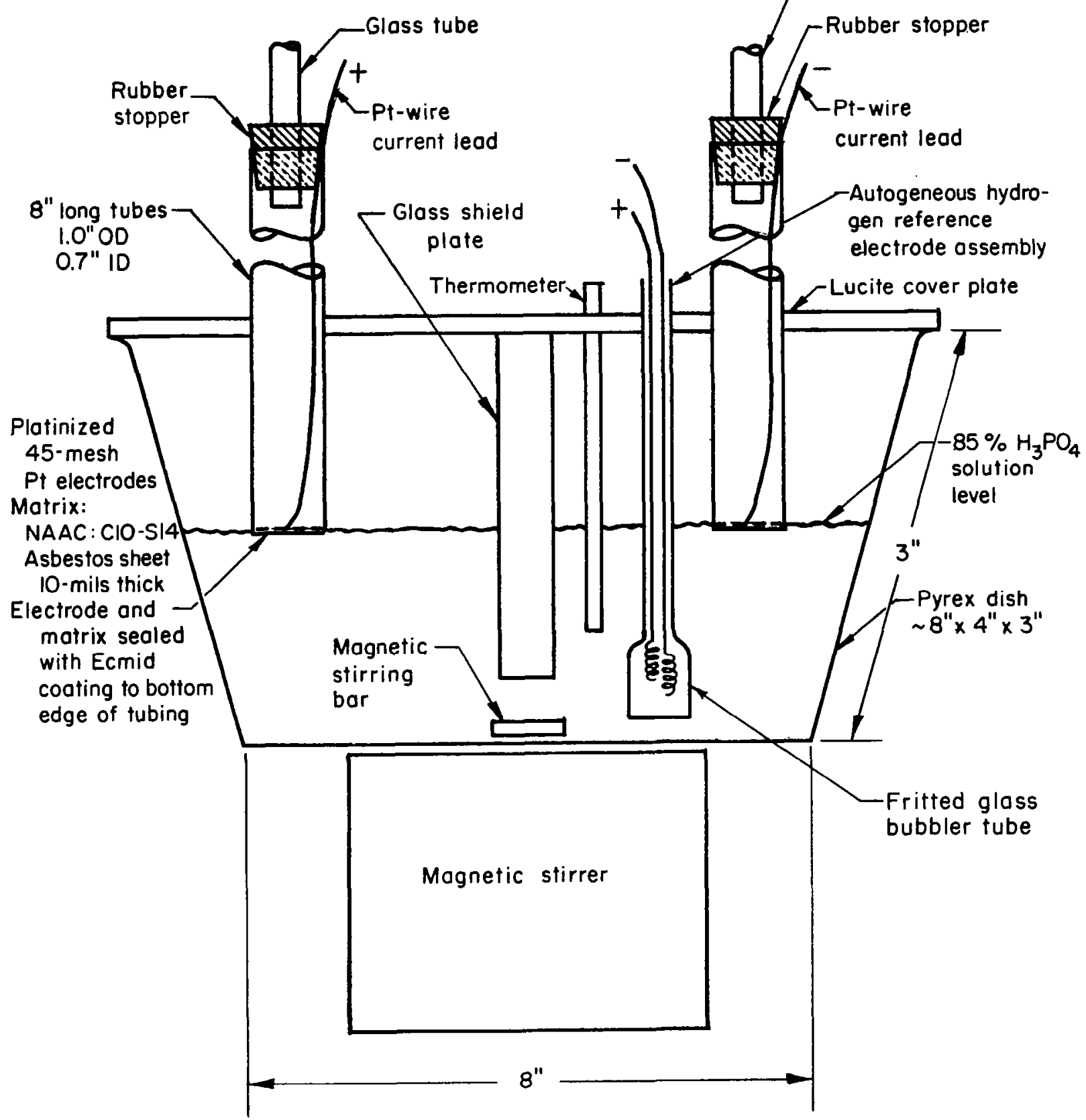

FIGURE 3. SKETCH OF LIQUID-MATRIX CELL ASSEMBLY (VA-3) USED FOR VOLTAGE ANALYSIS IN A CELL WITHOUT GAS IN TERMIXING 
Cell 2. Cell 2 was assembled primarily for voltage-analysis studies on a vapor cell operating under steady-state conditions. The matrix was a double-layer disk of 10-mil asbestos sheets (identified later) of 1.6-inch diameter (1.2-inch diameter effective for electrolysis) impregnated with 1.3 grams of 85 percent $\mathrm{H}_{3} \mathrm{PO}_{4}$. The anode and cathode were platinized platinum screen (45-mesh, 7.8-mil wire). A reference electrode (2-mil palladium-silver strip about $1 / 8$ inch wide) was inserted between the two matrix layers for voltage-analysis studies.

Sealing was inadequate and gas leakage occurred within the cell so that pure hydrogen gas could not be collected. Subsequent studies confirmed that the problems in cell design relating to gas intermixing did not adversely affect the cell voltage. The extended operation of this cell provided supporting evidence on the stability of the asbestos matrix and platinizedplatinum electrodes.

Experimental Cells

The term "experimental cell" is used to describe a single cell of one anode and one cathode with a composite matrix sandwiched between. At the beginning of this program, the "experimental cell" was adopted as the basic building block for construction of the "laboratory model" (10 seriesconnected experimental cells) and design of "prototype units" (various "laboratory model" units connected in parallel electrically). Several features of the experimental cells used in the laboratory model were "standardized" in the sense that they were not changed when found to be adequate for the present study. By this procedure the number of variables involved in the performance evaluation was reduced to allow more emphasis on dynamic factors.

Standard Features. The dimensions of the "experimental cell" were standardized as 2 by 2 inches based on the geometric area for each screen electrode. Current densities reported are based on the geometric electrode area and effective matrix area for electrolysis of 4 in. 2 .

The "standard composite matrix" used in all "experimental cells" (Cells 3, 4a, and $4 \mathrm{~b}$ ) and the battery of cells in the laboratory model consisted of one 33-mil microporous rubber (MPR) separator* sandwiched between two 10-mil-asbestos sheets. ** The matrixes of the "experimental

* A ce-Sil, flat microporous-rubber battery separator, American Hard Rubber Company, Butler, New Jersey; similar to material used in prior studies at Battelle (ref. 1).

* NORAMITE B, C-10-5-14, North American A sbestos Corporation, Chicago, Illinois. 
cells" were initially impregnated with various amounts of 85 percent $\mathrm{H}_{3} \mathrm{PO}_{4}^{*}$ (nominal composition of reagent grade chemical).

The platinum electrodes were commercially available woven screen (either 45-mesh, 7.8-mil wire or 80-mesh, 3-mil wire). Platinum lead wires were spot welded to the screen electrodes.

Platinized-platinum screen electrodes were.prepared using a platinum chloride solution ( 5 percent by weight of $\mathrm{H}_{2} \mathrm{PtCl}_{6} \cdot 5 \mathrm{H}_{2} \mathrm{O}$ ) which was diluted with distilled water about 2:1 to provide a platinum metal concentration of $1 / 2$ to 1 percent by weight. Lead acetate was added in the amount of $0.002 \mathrm{~g} / 1$ of $\mathrm{Pb}\left(\mathrm{C}_{2} \mathrm{H}_{3} \mathrm{O}_{2}\right)_{2}$ and the platinizing solution was used at room temperature. Usually, two screens ( 4 in ${ }^{2}$ each) were platinized together by making one the cathode and the other the anode at 0.8 ampcre for $2-1 / 2 \mathrm{~min}-$ utes and then reversing the polarity. The procedure was repeated four times for a total platinizing time of 20 minutes ( $8 \mathrm{amp}-\mathrm{min} / \mathrm{electrode})$. In one example, the weight gain of a single electrode was determined to be 0.065 gram.

The plastic air baffle was machined from polyvinylchloride with semicircular flutes 0.040 -inch deep, 8 per inch, in the air flow direction. The flute design which formed the air flow channel was standardized and theoretical equations for estimating pressure drop for this design are given in Appendix $C$. The ribs formed by the flutes in the plastic baffle served to keep the platinum screen electrode in contact with the matrix. The particular design provided a minimum of a contact area with the electrode and did not significantly reduce the effective vapor absorption or electrolysis area. Thus, an improvement is believed to have been made over gas-channel designs used in prior studies of the vapor cell.

Cell 3. Figure 4 shows the design of experimental Cell 3. This was the first attempt at a new lightweight design which weighed about 0.21 pound. A ribbed plastic baffle was used both for the hydrogen and air channels and the cell was contained in a plastic box to provide gas-port connections.

Internal sealing was found to be inadequate and pure hydrogen gas could not be collected. However, this did not adversely affect the cell voltage and evaluation of platinized-platinum electrodes and matrix during 1000 hours of extended operation. Compared to Cell 2, the principal difference in the matrix used for Cell 3 was the addition of a 33-mil microporous rubber separator.

*Throughout this report the terminology " 85 percent $\mathrm{H}_{3} \mathrm{PO}_{4}$ " means an electrolyte containing 85 weight percent of anhydrous phosphoric acid in an aqueous solution where the balance is 15 weight percent water. 

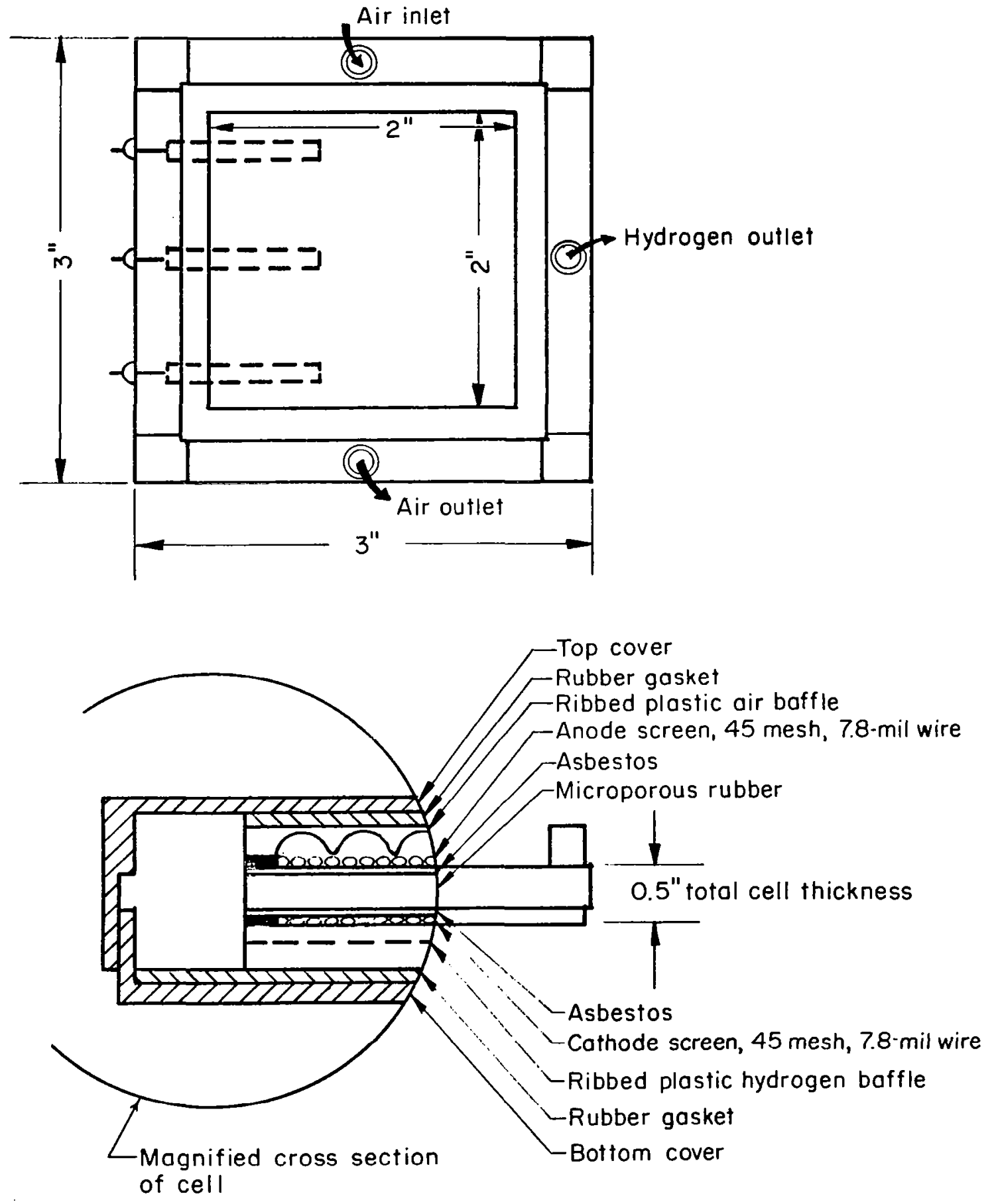

FIGURE 4. EXPERIMENTAL CELL 3 
Several unsuccessful attempts were made to provide a gastight seal for the cell design similar to. Cell 3 (figure 4). The leakage problem was at the corners of the box forming the gas ports rather than through the matrix.

Cell 4a. Cell 4a was a mock-up of a new experimental cell design which was easier to seal and also reduced cell weight. The matrix and cathode were combined in an integral unit sealed with silicone rubber. ${ }^{*}$ The previously used plastic ribbed baffle of the hydrogen chamber was replaced by a 15-mil sheet of microporous Teflon ${ }^{* *}$ positioned against the platinizedplatinum cathode. Hydrogen was removed through the Teflon which is not "wet" by phosphoric acid. After impregnation with 85 percent $\mathrm{H}_{3} \mathrm{PO}_{4}$, there was no leakage with a suction of 12 inches of water at the hydrogen collection burette. The platinized-platinum anode and plastic ribbed baffle were added during cell assembly with no need for an airtight seal of the oxygen compartment.

With electrolysis at $33 \mathrm{amp} / \mathrm{ft}^{2}$, the theoretical amount of hydrogen gas was collected and the cell voltage was 2.6 volts (the same as that of Cell 3 with a similar matrix and electrodes).

Cell 4b. Cell 4b (figure 5) was designed similar to Cell 4a and was used for extended operational testing.

A principal difference from Cell $4 \mathrm{a}$ was the use of thinner and finer mesh electrodes for both the anode and cathode (80-mesh, 3-mil wire, platinized platinum). Since vapor absorption through the anode screen did not appear to be the principal cause of high cell voltage, no difference in voltage characteristics was expected and this has been verified by measurement on Cell 4b. Actually, the 80-mesh screen with smaller wire size provides slightly more open area than the 45 -mesh screen with larger wire.

Cell $4 \mathrm{~b}$ was essentially a prototype of the cells constructed for the laboratory model. The principal design change required was a relocation of the hydrogen outlet to the side so that the cells could be stacked. The extra piece of 20-mil microporous Teflon of larger pore size (3-35 microns) on the hydrogen side as shown in figure 5 was also eliminated for the laboratory model.

\footnotetext{
* A white, adhesive, flexible rubber sealant marketed in squeeze-tube form which was easy to use for hand construction of cells. The silicone rubber air cures at room temperature and other similar products are available for molding, etc.

*MPT -87-1, 75.8 percent of pores are 3.9 microns' average, General Plastics Corporation, Bloomfield, New Jersey.
} 


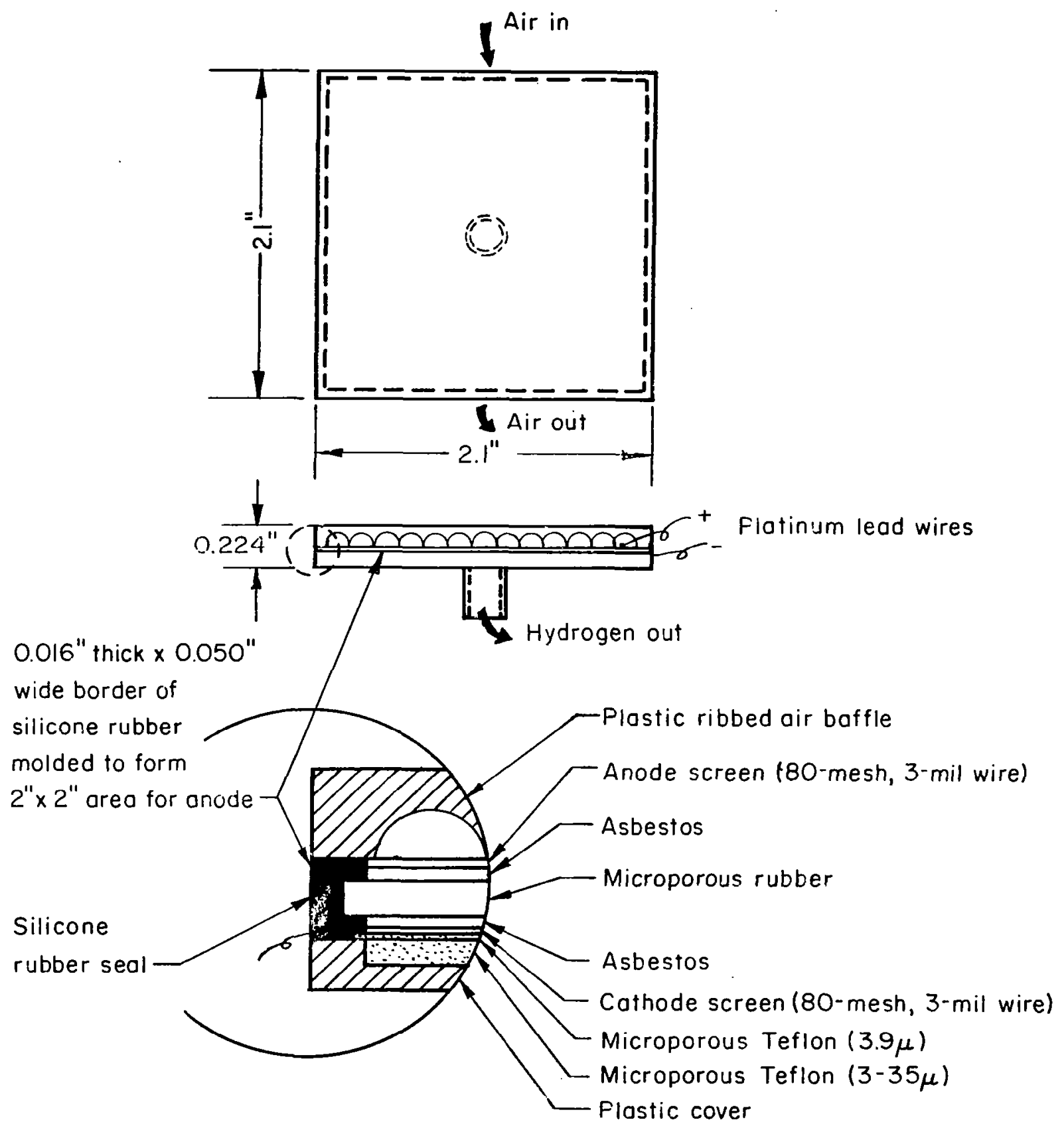

FIGURE 5. EXPERIMENTAL CELL 4b 
$\underline{\text { Laboratory Model }}$

The laboratory model was a battery of 10 identical experimental cells connected in series electrically. Figure 6 shows the detail of individual cell design for the laboratory model with dimensions. The method of construction of a single experimental cell (not an end cell) in the battery is described starting from the cathodic end of one cell.

The flat surface on one side of the air baffle provided the cover for the hydrogen compartment of the adjacent cell. A small hole of about 0.020-inch diameter was drilled into one edge at a 45-degree angle to provide an outlet for hydrogen. For the low hydrogen production rates of a single cell $\left(\sim 8 \mathrm{~cm}^{3} / \mathrm{min}\right.$ at $\left.33 \mathrm{amp} / \mathrm{ft}^{2}\right)$ a small hole was adequate. This was verified for the first cell made in which the theoretical amount of hydrogen was collected at $33 \mathrm{amp} / \mathrm{ft}^{2}$ without building up excessive pressures in the hydrogen compartment. The test also showed that the hydrogen could be collected at one edge by diffusion through the single 15-mil sheet of microporous Teflon. The test was important because the cell construction is not rigid; a back pressure of about 12 inches of water was inadvertently applied from the gas collection burette and the matrix deformed when not supported by the air baffle. To insure against an unusual back pressure on the hydrogen chamber, the laboratory model was operated with a water manostat in the main hydrogen-collection line to prevent hydrogen pressure in excess of about 1 inch of water.

The hydrogen gas diffused through the sheet of microporous Teflon which served both as a hydrogen-gas channel and cathode support. Possibly another function the microporous Teflon serves is to prevent loss of electrolyte from the cathode side because of the nonwetting characteristics of Teflon.

The cathodes and anodes of platinized-platinum (80-mesh, 3-mil wire) were identical except for the location of attachment of current leads. Calculations of the expected IR drop through the screen indicated the desirability of introducing the current at at least two edges (diagonally opposite). The current leads (intercell connectors) were 20-mil-diameter platinum, flattened to about $5 \mathrm{mils}$ for about $1 / 4 \mathrm{inch}$ and spot welded to the screen. The optimum intercell connectors to each electrode would have a total cross section larger than two 5-mil wires but somewhat less than the readily available 20-mil wire (trade-off of weight versus IR drop) and should be as short as possible. For the laboratory model, the intercell connectors were longer for ease of attaching individual cell-voltage-measurement leads.

For assembly the following parts were stacked in order, centered, and held in position with "C" clamps. Steel plate ( $1 / 4$ by 2.0 by 2.0 inches), air 


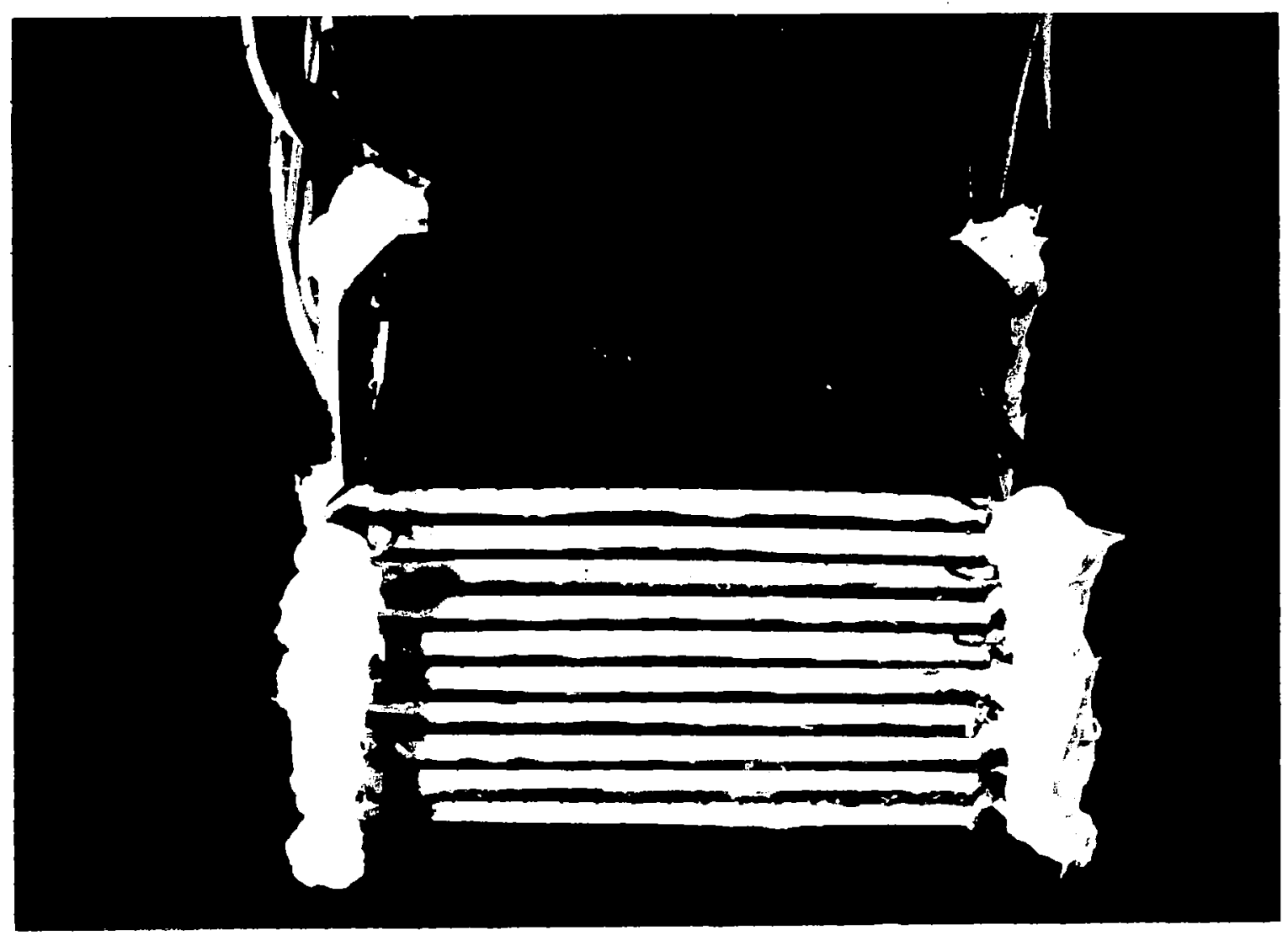

a. Photograph of Laboratory Model (Air Outlet End)

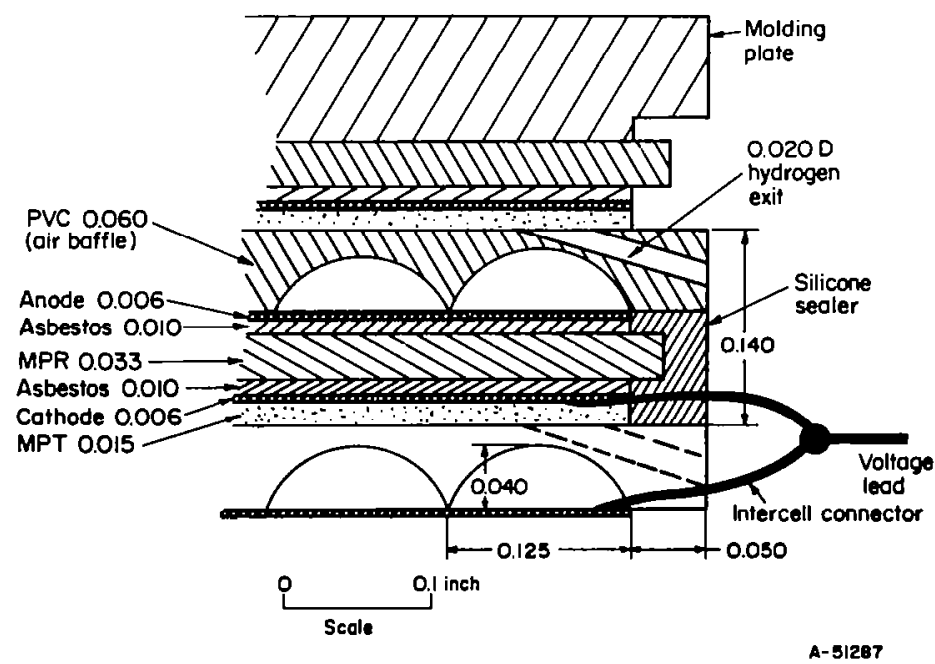

b. Schematic of Internal Cell Design

b. Schematic of Internal Cell Design

FIGURE 6. CELL DESIGN FOR LABORATORY MODEL 
baffle with flutes facing steel, microporous Teflon sheet, cathode screen, one sheet of asbestos, microporous rubber separator, and steel molding plate. The molding plate (shown in position on the top cell of figure $6 \mathrm{~b}$ ) had a 0.016 -inch recess in a 0.050 -inch-wide band around the bottom leaving dimensions of 2.0 by 2.0 inches. The edges of the cathode chamber and matrix assembly were sealed with silicon rubber. A squeeze tube was adequate for forcing the silicone rubber into the recess to form a $0.016-$ inch lip over the microporous rubber. The silicon rubber was allowed to air cure at room temperature overnight. The edges of the steel mold had previously been coated with a 2 percent Dreft solution to facilitate mold release. An injection molding fixture would have provided a neater job. For manual sealing, an excess of silicone rubber was used to insure sealing of hydrogen gas.

A small hypodermic needle tube was temporarily attached to the hydrogen outlet and pierced a rubber tubing connected to a burette. Prior to impregnation with acid, air was pulled through the matrix with a head of about 12 inches of water to insure that the small hydrogen port was not blocked.

The matrix was impregnated with $2.0 \mathrm{~cm}^{3}$ of 85 percent $\mathrm{H}_{3} \mathrm{PO}_{4}$ using a graduated pipette. After about $3 / 4$ of the acid had soaked into the microporous rubber, the second asbestos sheet (anode side) was fitted into the recess and the remaining acid added. After a few hours, the acid had soaked into the asbestos which was just moist on the surface. A suction of about 12 inches of water was maintained on the hydrogen outlet to show that there was no matrix leak.

For final assembly of the battery, the anode screen was positioned and held in place with the air baffle attached to the adjacent cell. The 10-cell stack was held together with black adhesive tape wrapped tightly around the unit with moderate hand pressure on the stack.

At this stage the laboratory model weighed 0.33 pound, which is considered a representative figure for use in estimation $\left(1.2 \mathrm{lb} / \mathrm{ft}^{2}\right.$ of electrode area).

The intercell connectors were soldered together with lead wires provided for individual cell-voltage measurement. The exposed intercell connector wires were coated with silicon rubber to avoid an inadvertent short circuit of the cells during experimental testing. Figure 6 a shows a photograph of the laboratory model. For experimental evaluation, a PVC tube was cemented along one side to collect the hydrogen from each cell, thermocouples were added, and a special Lucite fixture was used to minimize heat loss and provide for air-flow measurement. (The additional components for 
experimental evaluation are shown in figure 7 which appears later in the report).

Extended Operational Testing

Experimental Apparatus

Prior research studies had indicated the need for accurate control of inlet air humidity and temperature for proper interpretation of results. A special air-conditioning unit was used which can provide up to $140 \mathrm{ft}^{3} / \mathrm{min}$ of recirculated air over a wide range of temperatures and humidities, with temperature control of $\pm 1 \mathrm{~F}$ and absolute humidity control of \pm 5 percent. The conditioned air was recirculated through a 5-inch-diameter duct. The electrolysis cells were placed in the duct and a suction pump was used to draw air through the cells and a rotameter at a controlled rate.

In general, the degree of control of inlet air properties was adequate for research studies when the unit was functioning properly. However, during extended continuous operation there were several equipment failures (blown fuses, thyratron-tube failures, etc.) that adversely affected the electrolysis cells by subjecting them to abnormal humidity conditions. In general, the operation of the electrolysis cells for 1000 hours was far more reliable than the air conditioning equipment. Prior to evaluation of the laboratory model a special protective circuit was designed to protect the electrolysis unit which was operated at constant voltage. Abnormally high or low current values tripped microswitches attached to the current recorder which in turn shut off the air conditioner, vacuum pump, and rectifier that supplied direct current to the electrolysis cell.

For extended operational testing of single experimental cells, the nominal conditions are listed below with the degree of control that could be maintained.
Inlet Air Temperature
$85 \pm \mathbf{F}$
Inlet Humidity
$0.0130 \pm 0.00081 \mathrm{~b} \mathrm{H}_{2} \mathrm{O} / \mathrm{lb} \mathrm{DA}$
$(48-56 \% \mathrm{RH}))$
Relative Air Flow, n
$4.0 \pm 0.5^{*}$
Current Density
$32.8 \pm 0.7 \mathrm{amp} / \mathrm{ft}^{2}$.

*See Appendix C for definition of $n$. 
In general, the steady-state cell voltages were within \pm 0.05 volt with a few excursions to \pm 0.1 volt when control conditions were not maintained. With control close to the nominal values the cell voltage was \pm 0.02 volt.

The laboratory model unit was evaluated at the same inlet air temperature and humidity but at several battery voltage levels to achieve current densities in the range of $15-25 \mathrm{amp} / \mathrm{ft}^{2}$ and with higher relative air flow through the cells ( $n=6$ to 8 ).

The choice of inlet air temperature and humidity which was made at the beginning of the project was somewhat arbitrary since it was originally planned to investigate various combinations of inlet humidity from 0.010$0.018 \mathrm{lb} \mathrm{H} 2 \mathrm{O} / 1 \mathrm{~b} \mathrm{DA}$ and inlet temperature from 70-120 F. The values of $85 \mathrm{~F}$ and $0.0131 \mathrm{~b} \mathrm{H}{ }_{2} \mathrm{O} / \mathrm{lb} \mathrm{DA}$ were selected as nominal intermediate values. The nominal values do not represent a typical cabin air but provided representative conditions for evaluation of the vapor cell as discussed in later sections of this report.

The manner in which the experimental cells and laboratory model were tested is pertinent to interpretation of the operating performance. Figure 7 shows schematically how the cells were positioned in the 5-inch duct and also the attachment to the cell air outlet for drawing air through the cells at a controlled rate. As shown in figure $7 \mathrm{~b}$, the single experimental cells were not insulated. The air flow in the large duct was turbulent (although the air flow through the cells was laminar) and at $85 \mathrm{~F}$. It is estimated that 90 percent of the heat generated within the cell left the cell by convective cooling of the exposed outer surfaces of the cell; only about 10 percent of the heat was added to the air stream passing through the cell. Thus, for single experimental cells the electrolyte/matrix were operated at relatively low temperatures ( 90 F).

Figure $7 \mathrm{a}$ shows the box made of $3 / 8$-inch-thick Lucite that enclosed the laboratory model battery of cells. The box served as an attachment so that air could be drawn through the cells at a controlled rate and also provided sufficient insulation so that the convective heat loss was minimized. Over 90 percent of the heat generated in the cell was transferred to the air stream flowing through the cell so that investigation of high matrix/ electrolyte temperatures was possible.

\section{Gas Purity}

Air Stream. No analysis of the air stream was made during this study. The air supply to the air-conditioning unit operating at ambient 


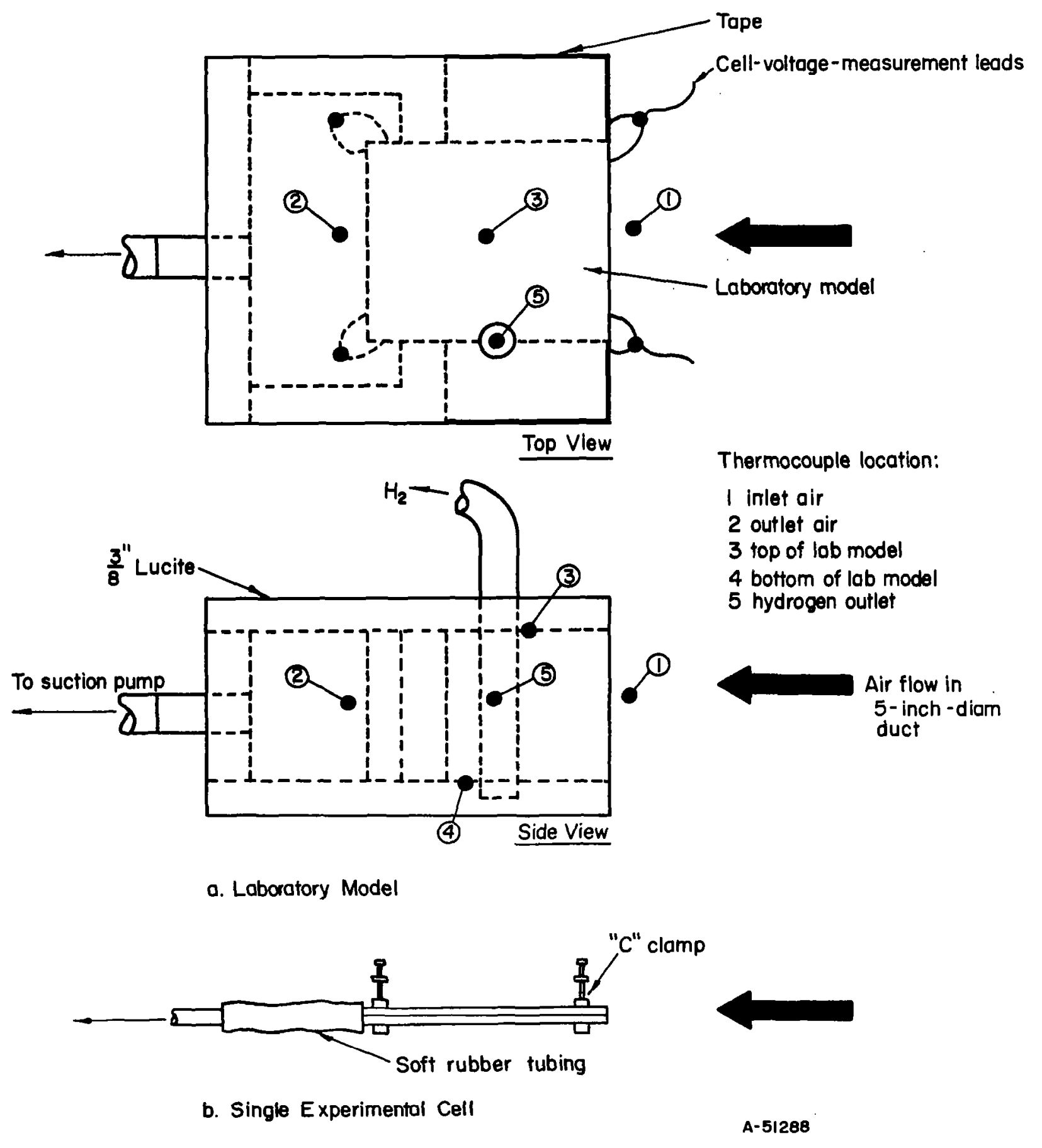

FIGURE 7. SCHEMATIC SHOWING SPECIFIC ARRANGEMENT OF VAPOR CELL IN AIR DUCT FOR EXPERIMENTAL TESTING AND LOCATION OF THERMOCOUPLES 
atmospheric pressure was obtained from the normal laboratory air (automatically in proportion to the air drawn from the system through the cells and exhausted back to the laboratory by the suction pump). Most likely the air contained the normal amount of carbon dioxide expected inside a normal air-conditioned room. Possibly, the air contained many other trace contaminants associated with a chemical laboratory atmosphere. There were no indications that the inlet air composition (other than water content) had any effect on performance of the vapor cell.

No attempt was made to analyze the outlet air from the vapor cell for hydrogen because of the large proportion of air to hydrogen. Accounting for the hydrogen generated according to Faraday's law is a simple and fairly accurate procedure compared to analyzing the air stream for hydrogen. For example, with a typical experimental cell, if one percent of the hydrogen were not accounted for, this would be about $0.07 \mathrm{~cm}^{3} / \mathrm{min}$. Assuming the hydrogen leaked into the air stream $(1300 \mathrm{~cm} / \mathrm{min})$ because of a defective matrix or sealing, the hydrogen would be diluted to about 0.005 percent. The latter accuracy was sufficient for the present study. More detailed study of the cumulative effect of impurities added to the air passing through the vapor cell would require a completely closed air loop and such an investigation was beyond the scope of the present study.

\section{Hydrogen Collection}

The primary purpose of hydrogen collection was to determine the actual rate of evolution for comparison with the theoretical rate. A value of $99+$ percent of the theoretical hydrogen rate was the criteria of acceptable cell sealing and also of an effective matrix that prevented cross leak of gas.

Hydrogen gas was collected over water in a burrette and the time to collect a $100-\mathrm{cm}^{3}$ sample was compared with the theoretical rate $16.97 \mathrm{~cm}^{3}$ $\mathrm{H}_{2}$ /amp-min at STP) corrected for temperature, pressure, and water vapor. The temperature ( $t, F)$ is the temperature of the water-jacketed burrette and the pressure (P) is the actual barometric pressure. [While the procedure of gas collection involves a suction of about 12 inches of water at the start, the gas pressure is atmospheric (with a leveling bulb) when the time measurement is made for $100 \mathrm{~cm}^{3}$ collected.] The hydrogen gas collected over water is assumed to be saturated with water vapor (vapor pressure, p) at the gas collection temperature $(t)$. The percentage of the theoretical rate is calculated as follows for the current (I): 


$$
\frac{\mathrm{cm}^{3} / \mathrm{min}(100)}{6.97\left(\frac{460+t}{492}\right)\left(\frac{760}{P-p}\right) I}=\% \text { of theoretical }
$$

Since the hydrogen was collected under a slight negative pressure, too great a rate was a definite indication of leakage of air into the hydrogen stream. When about the right rate of hydrogen was obtained, the gas was analyzed as a double-check and the results always indicated 97.7+ percent hydrogen which is the limit of accuracy of the catalytic-burner-type analyzer used.

EXPERIMENTAL DATA AND RESULTS

Voltage-Analysis Results

Measurement of Ohmic Polarization With

a Free Electrolyte

The ability of the current-interruption method to show changes in ohmic polarization $\left(E_{I R}\right)$ with current density was demonstrated using a cell without a matrix (Cell VA-1). The total cell ohmic polarization values were obtained from photographs of oscilloscope traces after current inter ruption and are given in table 1.

TABLE 1. COMPARISON OF OHMIC POLARIZATION FROM OSCILLOSCOPE TRACES WITH CALCULATED OHMIC POLARIZATION FROM CONDUCTIVITY DATA

\begin{tabular}{|c|c|c|c|c|}
\hline \multirow{2}{*}{$\begin{array}{l}\text { Cell } \\
\text { Current, } \\
\text { amp }\end{array}$} & \multirow{2}{*}{$\begin{array}{c}\text { Current } \\
\text { Density, } \\
\text { amp/sq ft }\end{array}$} & \multirow{2}{*}{$\begin{array}{c}\text { Cell } \\
\text { Voltage, } \\
\text { volts }\end{array}$} & \multicolumn{2}{|c|}{ Ohmic Polarization, $\mathrm{E}_{\mathrm{IR}}$} \\
\hline & & & $\begin{array}{c}\text { Oscilloscope Trace(a), } \\
\text { volts }\end{array}$ & $\begin{array}{c}\text { Calculat } A(b), \\
\text { volts }\end{array}$ \\
\hline 0.140 & 20 & 3. 18 & 0.53 & 0.53 \\
\hline 0.280 & 40 & 3.80 & 1.13 & 1.05 \\
\hline 0.420 & 60 & 4.35 & 1.53 & 1.57 \\
\hline
\end{tabular}

(a) The ohmic-polarization values for the cell were determined from photographs of the oscilloscope traces after current interruption and were picked up within about 5-7 microseconds. Ring-back effects at shorter times clouded the traces, making it difficult to obtain good data within times such as 1-2 microseconds. The ohmic polarization was considered to be the almost instantaneous change between the closed circuit voltage and the open-circuit voltage.

(b) The values were calculated using a specific conductivity value of $0.105 \mathrm{ohm}^{-1} \mathrm{~cm}^{-1}$ for 85 percent $\mathrm{H}_{3} \mathrm{PO}_{4}$ solution at $80 \mathrm{~F}$ (ref. 5) for a 1 -inch anode-to-cathode spacing in Cell VA-1. 
The ohmic polarization values varied linearly with current densities of 20 to 60 amperes/sq ft as predicted by equation 3. There was also good agreement of the oscilloscope ohmic-polarization values with the IRpolarization values calculated using conductivity data. The results given in table 1 indicate the suitability of the current-interruption technique to measure ohmic polarization, and show that cell resistance is virtually all within the electrolyte between the electrodes.

The experiments with the small glass cell were also used to observe the gassing action at the two electrodes in the 85 percent $\mathrm{H}_{3} \mathrm{PO}_{4}$ solution. The gassing action at the anode appeared more pronounced than at the cathode, even though twice the volume of gas was formed at the cathode. The size of the bubbles formed at the anode were considerably smaller (about 1/4-1/3 the size) than those formed at the cathode.

\section{Voltage Analysis of Matrix-Type Cells}

Following the ohmic-polarization studies with Cell VA-l with free electrolyte, Cells VA-2a and VA-2b with microporous rubber matrixes, impregnated with 85 percent $\mathrm{H}_{3} \mathrm{PO}_{4}$ solution were assembled for use in carrying out complete cell-voltage-analysis studies. The main objective of these studies was to further check out the suitability of the current-interruption method for voltage analysis of the water-vapor electrolysis cell.

Identification of Polarization Components. The polarization-decay curves for Cells VA-2a and VA-2b operating with plain-platinum and platinized-platinum electrodes are presented in figures 8 and 9, respectively.

Figure 8 shows that a curve with two different slopes was obtained from the oscilloscope-trace data for the anode versus reference electrode on the plot of potential versus log of time after current interruption. One slope was observed over the range of 1 to 100 microseconds [ $10^{-6}$ to $10^{-4}$ second] i. e., activation polarization); a different slope was noted in the range of 100 microseconds to 0.5 second (i.e., concentration polarization). The curve (bottom of figure 8 ) for the cathode versus reference electrode also shows two slopes; one slope covers the range from 1 to $250 \mathrm{mi}$ croseconds (i. e., activation polarization) and the other from 250 microseconds to 5 seconds (i.e., concentration polarization). The magnitude of the various individual polarization components is shown graphically in figures 8 and 9. The cell-voltage analysis data and results from figures 8 and 9 are summarized in table 2 . 


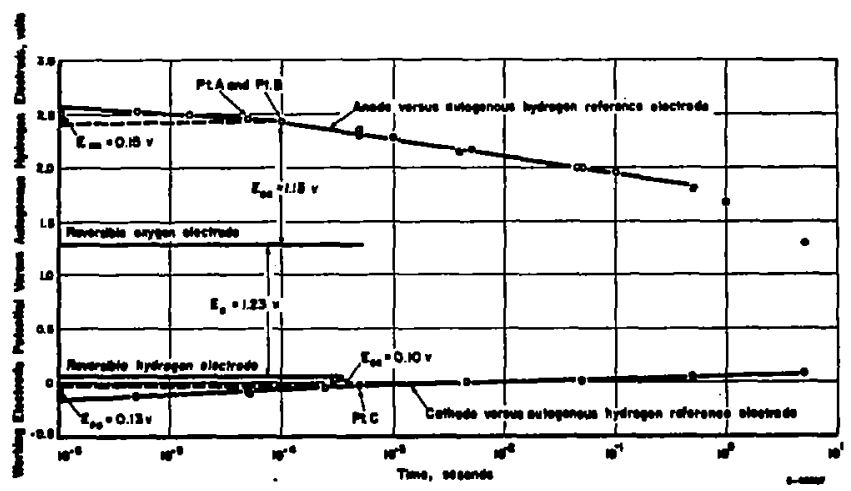

FIGURE 8. POLARIZATION-DECAY CURVES FOR MATRIX CELL (VA-2a) WITH PLAIN-PLATINUM ELECTRODES

Cell Data:

Platinum electrodes (45-mesh, 0.0078-inch-diam wire)

Microporous rubber matrix (one sheet of 0.033 -inch thickness)

Current density of $40 \mathrm{amp} / \mathrm{sq} \mathrm{ft}$

A rea of 0.8 square inch

Electrolyte 85 percent $\mathrm{H}_{3} \mathrm{PO}_{4}$

No air circulation

Autogenous hydrogen reference electrode potential plotted as zero.

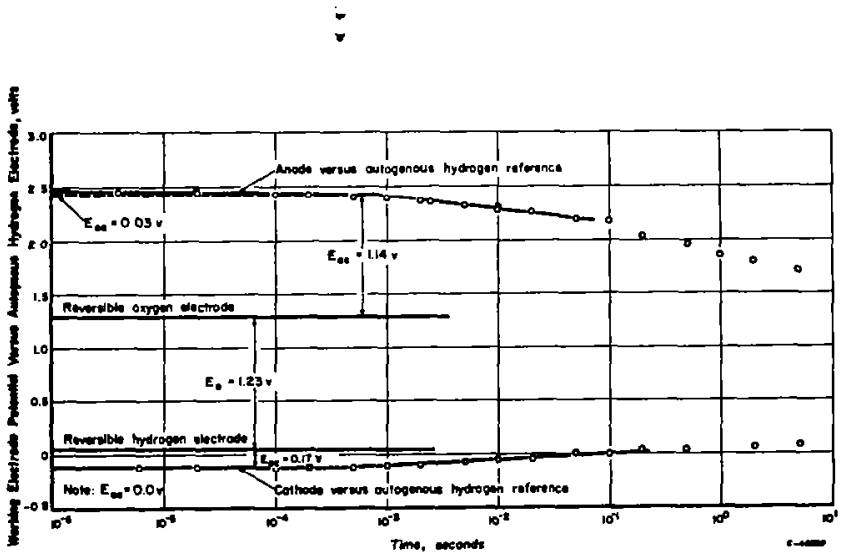

FIGURE 9. POLARIZATION-DECAY CURVES FOR MATRIX CELL (VA-2b) WITH PLATINIZEDPLATINUM ELECTRODES

Cell Data :

Platinized-platinum electrodes (45-mesh, 0.00780-inch-diam wire)

Microporous rubber matrix (two sheets of 0.033 -inch thickness)

Gurrent density of $51 \mathrm{amp} / \mathrm{sq} \mathrm{ft}$

Area of 0.8 square inch

Electrolyte 85 percent $\mathrm{H}_{3} \mathrm{PO}_{4}$

No air circulation

Autogenous hydrogen reference electrode potential plotted as zero. 
TABLE 2. VOLTAGE-ANALYSIS RESULTS FOR VAPOR CELLS (a,b)

\begin{tabular}{|c|c|c|}
\hline Item & $\begin{array}{l}\text { Plain-Platinum } \\
\text { Electrode Cell } \\
\text { (See Figure 8) }\end{array}$ & $\begin{array}{c}\text { Platinized-Platinum } \\
\text { Electrode Cell } \\
\text { (See Figure 9) }\end{array}$ \\
\hline Cell Designation & $\mathrm{VA}-2 \mathrm{a}$ & $V a-2 b$ \\
\hline Current Density, amp/sq ft & 40 & 51 \\
\hline Number of Matrixes in Cell & 1 & 2 \\
\hline Total Cell Voltage, volts & 2. 95 & 3.20 \\
\hline $\begin{array}{l}\text { Potential Anode Versus Autogenous } \\
\text { Hydrogen Electrode, volts }\end{array}$ & 2. 70 & 2.55 \\
\hline $\begin{array}{l}\text { Potential Cathode Versus Autogenous } \\
\text { Hydrogen Electrode, volts }\end{array}$ & 0.17 & 0.69 \\
\hline $\begin{array}{l}E_{\text {o, }} \text { Theoretical Cell Decomposition } \\
\text { Voltage, volts }\end{array}$ & 1.23 & 1.23 \\
\hline $\begin{array}{l}\mathrm{E}_{\text {aa }} \text {, Anode Activation Polarization, } \\
\text { volts }\end{array}$ & 0.15 & 0.03 \\
\hline $\begin{array}{l}E_{\text {ac, Anode Concentration Polarization, }} \\
\text { volts }\end{array}$ & 1.15 & 1. 14 \\
\hline $\begin{array}{l}\mathrm{E}_{\text {ca }} \text {, Cathode Activation Polarization, } \\
\text { volts }\end{array}$ & 0.13 & 0.00 \\
\hline $\begin{array}{l}\text { E }_{\text {cc }} \text {, Cathode Concentration } \\
\text { Polarization, volts }\end{array}$ & 0.10 & 0.17 \\
\hline $\mathrm{E}_{\text {IR }}$, Total Cell Ohmic Polarization, & 0.30 & 0.62 \\
\hline $\begin{array}{l}\text { Summation of Individual Voltage } \\
\text { Components, volts }\end{array}$ & 3.06 & 3. 19 \\
\hline
\end{tabular}

(a) See Figures 8 and 9 for more details on cell data. It should be especially noted that the cell with the platinized-platinum electrodes was operated at a higher current density and also that the matrix thickness ( 0.066 inch) was twice that of the cell with the plain-platinum electrodes.

(b) Slight changes of about $\pm 0.05 \mathrm{v}$ in cell voltage occurred during the course of making the voltage-analysis runs; these changes were not large enough to affect the overall cell analysis significantly. 
Although the data from figures 8 and 9 are not directly comparable because of differences in matrix thickness and current density of operation, they do provide useful information on cell performance. The use of platinized-platinum electrodes (figure 9) greatly reduced the anode activation polarization $\left(E_{a a}=0.03\right.$ volt) from that of the cell operating with plain platinum electrodes $\left(E_{a a}=0.15\right.$ volt $)$. The cathode activation overvoltage was eliminated by use of the platinized-platinum electrode (see figures 8 and 9 and also table 2).

The lowering of the activation polarization at both electrodes by use of platinized electrodes was as expected. Thus, a total cell-voltage lowering of about 0. 2 to 0.3 volt (at about 40-50 amp/sq ft current density) should be expected by the use of platinized-platinum electrodes as opposed to plainplatinum electrodes. For this reason, platinized-platinum electrodes were the preferred electrode material for use in the experimental laboratory and prototype cells. Data on the durability and effectiveness of the platinizedplatinum screen material on prolonged usage are discussed later.

From figures 8 and 9 , and table 2 , it is readily apparent that anode (oxygen) concentration polarization $\left(E_{a c}\right)$ constitutes the major component of the overall cell voltage. The values of $E_{a c}$ for the cells of figures 8 and 9. were 1.15 and 1.14 volts, respectively; while the values of $E_{c c}$ were 0.10 and 0.17 volt, respectively. From these data, it would appear that conditions surrounding the anode are the cause of most of the cell polarization.

Platinizing the electrodes (which provides a large true surface area and lower true current density) did not decrease the voltage components identified as concentration polarization. Thus, the concentration polarization is related to the geometric electrode area and varies with geometric current density as will be shown later by current/voltage curves. This might be expected for mass transfer (to or away from the electrode) through a diffusion film acting over a finite distance from the electrode surface. Thus, the results of platinizing appeared to be consistent with the effects expected for activation polatization and concentration polarization and supported the belief that the current-interruption technique was correctly identifying the cell voltage components.

The total cell ohmic resistance, $E_{I R}$ (see table 2), as determined by the current-interruption method for the cell with a single matrix thickness ( $0.033 \mathrm{inch}$ ) operated at $40 \mathrm{amp} / \mathrm{sq} \mathrm{ft}$ was 0.30 volt. For the other cell with twice the matrix thickness, the $E_{I R}$ value was 0.62 volt for a current density of $51 \mathrm{amp} / \mathrm{sq} \mathrm{ft}$. These values compare well with one another, and indicate that the resistance appears to be primarily in the matrix rather than at the matrix-electrode interface. Comparison of these $\mathrm{E}_{\mathrm{IR}}$ polarization values with those obtained for the liquid electrolyte cell (see table 1) indicates that 
the matrix contributes greatly to $\mathrm{E}_{\mathrm{IR}}$ voltage loss. For example at a current density of $4.0 \mathrm{amp} / \mathrm{sq}$ ft the $E_{I R}$ values per mil are as follows:

$$
\text { Free-liquid cell }(\mathrm{VA}-1): \frac{1.13 \mathrm{v}}{1000 \mathrm{mils}}=0.0011 \mathrm{volt} / \mathrm{mil}
$$

$$
\text { Matrix cell (VA-2a or VA-2b): } \frac{0.30 \mathrm{v}}{33 \mathrm{mils}}=0.0091 \mathrm{volt} / \mathrm{mil}
$$

Thus, for comparable electrolyte-space thicknesses, the presence of the microporous rubber matrix causes about an eightfold increase in $\mathrm{E}_{\text {IR }}$ polarization values. Accordingly, work on thinner or better matrix materials might possibly result in elimination of about 20 to 70 percent of $E_{I R}$ polarization.

Free-Liquid and Liquid-Matrix Cell

Experiments and Results

Continued research on the cause of the high anode-concentration polarization was carried out in beaker-scale experiments using free-liquid-type cells, where some of the complex factors existing in an operating vapor cell could be eliminated. This work was directed toward establishing:

(1) whether the anode-concentration polarization is characteristic of a free electrolyte of relatively concentrated acid (i. e., 85 percent $\mathrm{H}_{3} \mathrm{PO}_{4}$ ),

(2) whether airflow and water-absorption characteristics of the matrix are important factors that cause the relatively high voltage in the vapor cell, and (3) whether gas intermixing was affecting the cell-voltage components observed in operating Cells 2 and 3.

Liquid-Matrix Cell. To simulate a cell with gas evolved to a gas phase, and one in which gas intermixing was prevented, the liquid-matrix cell assembly (VA-3) shown earlier in figure 3 was used. Electrolysis was carried out in 85 percent $\mathrm{H}_{3} \mathrm{PO}_{4}$ solution at 85-90 F. The currentinterruption method of voltage analysis was used. Data and results of these studies are given in table 3 and were compared with similar results for operating experimental Cells 2 and 3 (shown later in table 6).

Voltage-analysis results of table 3 indicated a high anode-concentration polarization $\left(E_{a c}=1.09\right.$ volts at $\left.33 \mathrm{amp} / \mathrm{sq} \mathrm{ft}\right)$ similar to that of the operating vapor cells (i.e., Cells 2 and 3). Values of cathode-concentration polarization $\left(E_{\mathrm{cc}}\right)$, anode-activation polarization $\left(E_{\mathrm{aa}}\right)$, and cathode activation 
TABLE 3. VOLTAGE ANALYSES FOR FREE LIQUID AND LIQUID/MATRIX CELLS

\begin{tabular}{|c|c|c|c|c|}
\hline \multirow[b]{2}{*}{ Item } & \multicolumn{2}{|c|}{ Liquid/Matrix Cell } & \multicolumn{2}{|c|}{ Free-Liquid Cell } \\
\hline & $\begin{array}{c}\text { Individual- } \\
\text { Electrode } \\
\text { Cell } \\
\text { Analysis }\end{array}$ & $\begin{array}{l}\text { Total- } \\
\text { Cell } \\
\text { Analysis }\end{array}$ & $\begin{array}{c}\text { Individual- } \\
\text { Electrode } \\
\text { Cell } \\
\text { Analysis }\end{array}$ & $\begin{array}{c}\text { Total- } \\
\text { Cell } \\
\text { Analysis }\end{array}$ \\
\hline Average Current Density, amp/sq ft & 33 & 33 & 33 & 33 \\
\hline Total Cell Voltage, volts & 3. 41 & 3. 42 & 3.14 & 3. 18 \\
\hline Potential Anode Versus Autogenous Hydrogen Electrode, volts & 2. 90 & -- & 2.83 & -- \\
\hline Potential Cathode Versus Autogenous Hydrogen Electrode, volt & 0.51 & -- & 0.30 & -- \\
\hline $\mathrm{E}_{\mathrm{o}}$, Theoretical Cell-Decomposition Voltage, volts & 1.23 & 1.23 & 1.23 & 1.23 \\
\hline $\mathbf{E}_{\mathrm{aa}}$, Anode-Activation Polarization, volt & 0.04 & -- & 0.05 & -- \\
\hline $\mathbf{E}_{\mathrm{ac}}$, Anode-Concentration Polarization, volt & 1.09 & -- & 1.18 & -- \\
\hline $\mathrm{E}_{\mathrm{ca}}$, Cathode-Activation Polarization, volt & 0.00 & -- & 0.00 & -- \\
\hline$E_{c c}$, Cathode-Concentration Polarization, volt & 0.07 & -- & 0.06 & -- \\
\hline$E_{\text {IR, Total-Cell Ohmic Polarization, volt }}(\mathrm{c})$ & 0.95 & 0.95 & 0.67 & 0.67 \\
\hline $\mathrm{E}_{\text {ta }}$, Total-Cell Activation Polarization, volt & $E_{a a_{0.04}}+E_{c a}$ & 0.05 & $\begin{array}{c}E_{\mathrm{aa}}+E_{\mathrm{ca}} \\
0.05\end{array}$ & 0.04 \\
\hline$E_{t c}$, Total-Cell Concentration Polarization, volt & $\begin{array}{c}E_{a c}+E_{c c} \\
1.16\end{array}$ & 1. 18 & $\begin{array}{c}E_{a c}+E_{c c} \\
1.24\end{array}$ & 1.25 \\
\hline
\end{tabular}

(a) See text of report for cell details and operating conditions.

(b) Slight changes of about $\pm 0.03 \mathrm{v}$ in cell voltage occurred during the course of making the voltage-analysis runs; these changes were not large enough to affect the overall cell analysis significantly.

(c) The $E_{\mathbb{R}}$ polarization values are characteristic of the geometry of the experimental cells used. 
$\left(E_{c a}\right)$ were small and generally similar in magnitude to the values observed for operating vapor cells. These results also showed that gas intermixing was not affecting the cell voltages being observed in the operating cells ( 2 and 3).

When electrolysis was first carried out in the apparatus shown in figure 3, with only a platinized-platinum screen electrode and no matrix, severe gas polarization occurred. As electrolysis progressed gas blocking on the electrolyte side of the screen increased in magnitude, so that within about 10 minutes, the cell voltage rose from about 3.5 volts to $15-18$ volts at $33 \mathrm{amp} / \mathrm{sq}$ ft (based on original electrode-screen area). Thus, the matrix appears to have a very important function in gas discharge at a screen electrode that was not fully appreciated earlier.

Free-Liquid Cell. Further voltage-analysis studies were carried out in a free-liquid cell (VA-la). Platinum-sheet electrodes (platinized on one side and insulated on the back side; electrolysis area 1 by 1 inch; faced each other 1 inch apart) were immersed in a free electrolyte of 85 percent $\mathrm{H}_{3} \mathrm{PO}_{4}$ $(85-90 \mathrm{~F})$. Again, the anode concentration polarization was high $\left(\mathrm{E}_{\mathrm{ac}}=\right.$ 1.18 volts at $33 \mathrm{amp} / \mathrm{sq} \mathrm{ft}$ ). Cell-voltage breakdowns on both the individualelectrode, and total-cell basis are given in table 3. The magnitude of the various voltage-polarization components were similar to those of the two operating vapor cells, 2 and 3 . The important result was that the concentration polarization was not lower with a free-electrolyte of 85 percent $\mathrm{H}_{3} \mathrm{PO}_{4}$ than observed with the vapor cells. The fact that the concentration polarization was actually lower in Cells 2 and 3 meant that the steady-state temperature of the electrolyte was higher or the steady-state electrolyte concentration lower in the operating vapor cells than used for the beakerscale experiments.

Tergitol $08^{*}$, an anionic-type wetting agent stable in phosphoric acid, was added to the free-liquid cell in concentrations ranging from 0.01 to $0.1 \mathrm{~g} / 1$ (which is the recommended concentration range for plating operations) to observe whether the surfactant effect would lower cell voltage. Although the gas bubbles at both electrodes appeared slightly smaller, there was no effect on total cell voltage. Increasing the Tergitol concentration to $17 \mathrm{~g} / 1$ in the electrolyte had no significant effect on cell voltage; foaming was greater at the higher wetting-agent concentration. Thus, no beneficial lowering of cell-voltage was observed.

The conclusion from the results of the above experiments with the free-liquid cells, is that high anode-concentration polarization is

Sodium 2-ethylhexyl sulfate; Union Carbide Corporation. 
characteristic of electrolysis of concentrated phosphoric acid. 'This was an important item to establish, because research on air flow, humidity, vaporabsorption characteristics, etc., could have no significant effect on reducing anode-concentration polarization below that characteristic of the steadystate electrolyte concentration in the matrix of a vapor cell (probably between 65 and 85 percent $\mathrm{H}_{3} \mathrm{PO}_{4}$ ). Thus future research to further identify and reduce anode concentration polarization could be carried out in beakerscale experiments using cells with a free electrolyte at a known concentration and temperature.

Effects of Phosphoric Acid Concentration and Temperature on Cell Voltage

A knowledge of the magnitude of the change in concentration polarization that could be achieved by variations in temperature and concentration of the phosphoric acid electrolyte is important for analyzing the factors contributing to the vapor-cell voltage. The fact that useful data on concentration polarization can be obtained in free-liquid cells was established and reported earlier. The earlier work had been done using the current-

inter ruption method of voltage analysis, whereas the results reported herein were obtained using the current/voltage-curve technique.

Increasing the temperature and decreasing the phosphoric acid concentration in the range from 96 to $25 \% \mathrm{H}_{3} \mathrm{PO}_{4}$ lowered cell voltage. The magnitude of the changes is shown in table 4 . The constants for the cellvoltage equations are also given in table 4 . The values of the constant "a" (which do not include any IR effect characteristic of free-liquid cell geometry) are especially indicative of the effect of temperature and electrolyte concentration on concentration polarization.

Overvoltage $\left(E_{\text {OV }}\right)$ data for a current density of 32.8 ASF are presented at the right of table 4 . See footnote (d) for details of the calculations of the $E_{\text {ov }}$ values. The $E_{\text {ov }}$ value consists of the $E_{\text {ta }}$ (total-cell activation polarization) and the $E_{t c}$ (total-cell concentration polarization). From earlier voltage-analysis work with platinized-platinum electrodes in phosphoric acid solutions, $E_{\text {ta }}$ amounts to about 5 percent of the $E_{o v}$ while $E_{t c}$ accounts for the remaining 95 percent.

From these studies it is evident that even by big changes in acid concentration [i.e., from 96 to 62.5 percent $\mathrm{H}_{3} \mathrm{PO}_{4}$ (which constitutes most of the range for a workable vapor cell)] the concentration polarization cannot be markedly reduced. Lowering by about 0.20 volt in concentration polarization can be achieved by use of a $62.5 \% \mathrm{H}_{3} \mathrm{PO}_{4}$ solution as opposed to a $96 \% \mathrm{H}_{3} \mathrm{PO}_{4}$ solution at comparable temperatures. The concentration 
TABLE 4. EFFECT OF PHOSPHORIC ACID CONCENTRATION AND TEMPERATURE ON CELL VOLTAGE ${ }^{(a)}$

\begin{tabular}{|c|c|c|c|c|c|c|c|c|}
\hline \multirow{3}{*}{$\begin{array}{l}\text { Phosphoric Acid } \\
\text { Concentration (b), } \\
\text { wt percent }\end{array}$} & \multirow{3}{*}{$\begin{array}{c}\text { Temperature, } \\
\text { F }\end{array}$} & \multicolumn{3}{|c|}{ Cell Voltage (a), volts } & \multirow{2}{*}{\multicolumn{3}{|c|}{$\begin{array}{c}\text { Constants for } \\
\text { Equation }(\mathrm{c}) \\
\mathrm{E}=\mathrm{a}+\mathrm{b} \log \mathrm{i}+\mathrm{ci}\end{array}$}} & \multirow{3}{*}{$\begin{array}{c}\text { Overvoltage Values at } \\
32.8 \mathrm{ASF}(\mathrm{d}, \mathrm{e}) \\
\mathrm{E}_{\mathrm{OV}}=\underset{\text { volts }}{\mathrm{E}_{32.8 \mathrm{ASF}}-\mathrm{E}_{\mathrm{IR}}-\mathrm{E}_{\mathrm{O}^{\prime}}}\end{array}$} \\
\hline & & $27.0 \mathrm{ASF}$ & $10 \mathrm{ASF}$ & $1 \mathrm{ASF}$ & & & & \\
\hline & & $E_{1}$ & $\mathrm{E}_{2}$ & $\mathbf{E}_{3}$ & a & $\mathrm{b}$ & c & \\
\hline \multirow[t]{3}{*}{96} & 87 & 2.861 & 2.443 & 2.060 & 2.041 & 0.209 & 0.0193 & 1.07 \\
\hline & 102 & 2.731 & 2. 370 & 2.022 & 2.006 & 0.203 & 0.0161 & 1.05 \\
\hline & 121 & 2.570 & 2.301 & 1.999 & 1.989 & 0.207 & 0.0106 & 1.01 \\
\hline \multirow[t]{2}{*}{85} & 86 & 2.647 & 2.318 & 1.977 & 1.963 & 0.216 & 0.0139 & 1.06 \\
\hline & 117 & 2.434 & 2.185 & 1.957 & 1.946 & 0.125 & 0.0114 & 0.98 \\
\hline \multirow[t]{4}{*}{62.5} & 85 & 2.239 & 2.081 & 1.874 & 1.869 & 0.159 & 0.0053 & 0.85 \\
\hline & 104 & 2.194 & 2.052 & 1.849 & 1.845 & 0.165 & 0.0042 & 0.83 \\
\hline & 121 & 2.160 & 2.034 & 1.803 & 1.801 & 0.213 & 0.0020 & 0.82 \\
\hline & 145 & 2.107 & 1.979 & 1.745 & 1. 743 & 0.215 & 0.0021 & 0.78 \\
\hline \multirow[t]{3}{*}{25} & 85 & 2.187 & 2.004 & 1.785 & 1.779 & 0.159 & 0.0067 & 0.75 \\
\hline & 102 & 2.173 & 1.983 & 1.750 & 1.743 & 0.172 & 0.0068 & 0.75 \\
\hline & 127 & 2.119 & 1.939 & 1.744 & 1. 737 & 0.128 & 0.0074 & 0.75 \\
\hline
\end{tabular}

(a) Data were obtained in a small rectangular free-liquid cell (VA-1b). Platinized-platinum sheet electrodes, positioned in Teflon picture-type frames so as to present a 1 by 1 -inch area were used. The electrodes were spaced 0.5 inch apart. Values were obtained during decreasing current (<i) half of the current/voltage cycle.

(b) The concentrations are expressed as weight percent of anhydrous orthophosphoric acid $\left(\mathrm{H}_{3} \mathrm{PO}_{4}\right)$ in an aqueous solution, where the balance is weight percent water.

(c) For details and a discussion of the current/voltage technique and the derivation of equations see report text. The equations used for this work (where $\mathrm{E}$, measured at $27 \mathrm{ASF}$ ) were:

$$
\begin{aligned}
& c=\frac{E_{1}+0.431 E_{3}+1.431 E_{2}}{13.12} \\
& a=E_{3}-c \\
& b=E_{2}-10 c-a .
\end{aligned}
$$

(d) The overvoltage values $\left(\mathrm{E}_{\mathrm{ov}}\right.$ ) were calculated using either a measured or extrapolated (from current/voltage curve) value of $\mathrm{E}$ at $32.8 \mathrm{ASF}$ (which is the current density at which the vapor cells have been run), and subtacting $\mathrm{E}_{\mathrm{IR}}$ (ohmic polarization) and $\mathrm{E}_{\mathrm{o}}$ (theoretical decomposition voltage) value of 1.23 volts.

(e) The $E_{I R}$ values were calculated using specific conductance values from ref. 4. 
polarization for the 62.5 to $96 \% \mathrm{H}_{3} \mathrm{PO}_{4}$ solutions ranged from about 0.8 to 1.0 volt, which is a significant amount of the total cell voltage. The concentration polarization is still high (i.e., 0.7 volt) even with the relatively dilute $25 \% \mathrm{H}_{3} \mathrm{PO}_{4}$ solution. Thus, high concentration polarization appears to be characteristic of phosphoric acid solutions and possibly acid solutions in general.

\section{Effects of Sulfuric Acid Concentration}

and Temperature on Cell Voltage

The effects of variations in phosphoric acid concentration and temperature were described above. To check whether the relatively high overvoltage values encountered with the vapor cell were characteristic of phosphoric acid solutions in particular or of acids in general, current/voltage data were obtained on sulfuric acid electrolytes using a free-liquid cell. Relatively concentrated sulfuric acid solutions were selected to cover a range (50-77 percent $\mathrm{H}_{2} \mathrm{SO}_{4}$ ) that might be considered for a vapor cell. Increasing the temperature and decreasing the sulfuric acid concentration lowered cell voltage. The magnitude of the changes is shown in table 5 . The constants for the cell-voltage equation are also given.

A comparison of the overvoltage $\left(E_{o v}\right)$ data for sulfuric acid electrolytes (table 5) with that for phosphoric acid electrolytes (table 4) indicates that only about a 0.1 volt lowering might be achieved with the sulfuric acid electrolytes. The overvoltage values ranged from about 0.7 to 0.9 for the sulfuric acid solutions as opposed to values of 0.8 to 1.0 volt for phosphoric acid solutions for comparable acid-concentration ranges. The above results taken in conjunction with the phosphoric acid results indicate that high overvoltages (mostly concentration polarization) are probably characteristic of acid solutions in general which have a sufficiently low equilibrium water vapor pressure for operation on cabin air.

\section{Extended Operational Testing Results}

Electrochemical Reliability

Several experimental cells were operated continuously for over 1000 hours or more to determine if there was any deterioration in performance with time that would adversely affect operational reliability. 


\begin{tabular}{|c|c|c|c|c|c|c|c|c|}
\hline \multirow{3}{*}{$\begin{array}{l}\text { Sulfuric Acid } \\
\text { Concentration } \\
\text { (b) } \\
\text { wt percent }\end{array}$} & \multirow{3}{*}{$\begin{array}{c}\text { Temperature, } \\
\text { F }\end{array}$} & \multicolumn{3}{|c|}{ Cell Volgage(a), volts } & \multirow{2}{*}{\multicolumn{3}{|c|}{$\begin{array}{c}\text { Constants for } \\
\text { Equation(c) } \\
\mathrm{E}=\mathrm{a}+\mathrm{b} \log \mathrm{i}+\mathrm{ci}\end{array}$}} & \multirow{3}{*}{$\begin{array}{c}\text { Overvoltage Values at } \\
32.8 \mathrm{ASF}(\mathrm{d}, \mathrm{e}) \\
\mathrm{E}_{\mathrm{OV}}=\mathrm{E}_{32.8 \mathrm{ASF}}-\mathrm{E}_{\mathrm{IR}}-\mathrm{E}_{\mathrm{o}^{\prime}}\end{array}$} \\
\hline & & \multirow{2}{*}{$\begin{array}{c}27.0 \mathrm{ASF} \\
\mathrm{E}_{1}\end{array}$} & \multirow{2}{*}{$\begin{array}{c}10 \mathrm{ASF} \\
\mathrm{E}_{2}\end{array}$} & \multirow{2}{*}{$\begin{array}{c}1 \mathrm{ASE} \\
\mathrm{E}_{3}\end{array}$} & & & & \\
\hline & & & & & $a$ & $\mathrm{~b}$ & c & \\
\hline \multirow[t]{3}{*}{77} & 84 & 2.403 & 2.210 & 1.858 & 1.855 & 0.325 & 0.0030 & 0.93 \\
\hline & 102 & 2.322 & 2.154 & 1.806 & 1.804 & 0.335 & 0.0015 & 0.86 \\
\hline & 130 & 2.259 & 2.105 & 1.760 & 1.760 & 0.343 & 0.0002 & 0.73 \\
\hline \multirow[t]{4}{*}{50} & 85 & 2.134 & 2.021 & 1.827 & 1.825 & 0.173 & 0.0023 & 0.85 \\
\hline & 102 & 2.093 & 1.990 & 1.802 & 1.801 & 0.179 & 0.0009 & 0.82 \\
\hline & 122 & 2.062 & 1.956 & 1.769 & 1.767 & 0.171 & 0.0018 & 0.79 \\
\hline & 145 & 1.987 & 1.890 & 1.705 & 1.704 & 0.172 & 0.0014 & 0.73 \\
\hline
\end{tabular}

(a) Data were obtained in a small rectangular free-liquid cell (VA-1b). Platinized-platinum sheet electrodes, positioned in Teflon picture-type frames so as to present a 1 by 1 -inch area were used. The electrodes were spaced 0.5 inch apart. Values were obtained during decreasing current ( $<$ i) half of the current/voltage cycle.

(b) The concentrations are expressed as weight percent of anhydrous sulfuric acid $\left(\mathrm{H}_{2} \mathrm{SO}_{4}\right)$ in an aqueous solution, where the balance is weight percent water.

(c) For details and a discussion of the current/voltage technique and the derivation of equations see report text. The equations used for this work (where $\mathrm{E}$, measured at $27 \mathrm{ASF}$ ) were:

$$
\begin{aligned}
& c=\frac{E_{1}+0.431 E_{3}+1.431 E_{2}}{13.12} \\
& a=E_{3}-c \\
& b=E_{2}-10 c-a .
\end{aligned}
$$

(d) The overvoltage values $\left(E_{O V}\right)$ were calculated using either a measured or extrapolated (from current/voltage curve) value of $\mathrm{E}$ at $32.8 \mathrm{ASF}$ (which is the current density at which the vapor cells have been run), and subtracting $\mathrm{E}_{\mathrm{IR}}$ (ohmic polarization) and $\mathrm{E}_{\mathrm{o}}$ (theoretical decomposition voltage) value of 1.23 volts.

(e) The $E_{I R}$ values were calculated using specific conductance values derived from data given in (ref. 6) and correcting the data for temperature by use of the specific conductance - temperature equation: $k_{t}=k_{18}[1+b(t-18)]$; a value of 0.013 was used for $b$ (ref. 7). 
Considering the experimental nature of the program, the duration of operational performance obtained with the experimental cells is considered a new and significant result:

$\begin{array}{lr}\text { Experimental Cell 2 } & 1300 \text { hours } \\ \text { Experimental Cell 3 } & 1100 \text { hours } \\ \text { Experimental Cell 4b } & 1380 \text { hours } \\ \text { Laboratory Model } & \begin{array}{r}342 \text { hours (through report } \\ \text { period and test continuing) }\end{array}\end{array}$

In each instance, the test of an experimental cell achieved the arbitrary selected goal of 1000 hours and the test was terminated by failure of the experimental equipment to maintain normal test conditions rather than failure of the cell components. The laboratory model test is continuing and the fact that the first ten "experimental cells" fabricated for the laboratory model all operated for over 300 hours is considered another indication of reliability.

The positive indications of electrochemical reliability are emphasized first so as not to be obscured by the more detailed discussion of areas in which there was not completely satisfactory cell performance.

The important criteria of satisfactory performance were:

(1) Ability to achieve and maintain steady-state operation with respect to water vapor absorption and electrolysis without "flooding" or appreciable loss of electrolyte by entrainment in the air stream

(2) Voltage stability at constant current density and constant input air properties (humidity, temperature, air flow rate)

(3) Stability of platinized-platinum electrodes and matrix at the steady-state conditions of electrolyte concentration and temperature

(4) Ability of matrix to prevent intermixing of hydrogen and oxygen for the steady-state electrolyte concentration. 
Voltage-Analysis Results for Cells 2,

3 , and $4 b$

Current-Interruption Method. Total cell-voltage analyses using the current-interruption technique were made on Cells 2 and 3 early (at 300 and 100 hours, respectively) in their steady-state operating periods and after extended operation (1100 and 910 hours, respectively). No significant changes in the voltage-analysis pattern were observed after about an 800hour interval with either cell. The results indicated good performance of the cells, and good stability of the electrodes and matrix materials for extended cell operation.

Total cell voltage (anode versus cathode) analyses were used to check cell performance since they do not require use of a reference electrode. The total cell voltage breakdowns, taken from the polarization-decay curves, are given in table 6 . The general pattern of the total polarization curves for both cells were similar to that shown for the anode-versus-reference electrode in figure 9. Voltage analysis data for Cell $4 \mathrm{~b}$ at 960 hours are also given in table 6.

Concentration Polarization. The voltage-analysis results (see table 6) verify that, in operating cells under steady-state conditions, the concentration polarization is the major component of cell overvoltage. Prior voltage analyses have shown that most of the concentration polarization is at the anode. The total concentration polarization $\left(E_{t c}\right)$ values for the three cells were $0.98 \pm 0.03$ volt.

Activation Polarization. The total cell activation voltage $\left(E_{t a}\right)$ is small for platinized-platinum electrodes in vapor cells (mostly at the anode). The $\mathrm{E}_{\mathrm{ta}}$ values were 0.04 volt for Cells 2 and 3 after prolonged operation; this corresponds to a small rise of 0.01 and 0.02 volt for Cells 2 and 3 , respectively, after an interval of about 800 hours between the times at which cellvoltage analyses were made. These results are indicative of the good stability of the platinized-platinum electrodes for effectively minimizing the activation polarization for 900-1100 hours or more of cell operation.

Ohmic Polarization. The difference in ohmic polarization between Cell 2 and Cells 3 or $4 \mathrm{~b}$ relates to the difference in matrix thickness. The ohmic polarization measurements included some IR drop in the cell leads as indicated in footnotes (d) and (e) of table 6. 
TABLE 6. TOTAL CELL-VOLTAGE ANALYSIS DURING STEADY-STATE OPERATION NEAR START AND END OF EXTENDED RUNS $(a, b, c)$

\begin{tabular}{|c|c|c|c|c|c|}
\hline \multirow[b]{2}{*}{ Item } & \multicolumn{2}{|c|}{$\begin{array}{c}\text { Cell } 2 \\
\text { at }\end{array}$} & \multicolumn{2}{|c|}{$\begin{array}{r}\text { Cell 3 } \\
\text { at } \\
\end{array}$} & \multirow{2}{*}{$\begin{array}{c}\text { Cell 4b } \\
\text { at } \\
960 \mathrm{Hr}\end{array}$} \\
\hline & $\overline{300 \mathrm{Hr}}$ & $1100 \mathrm{Hr}$ & $100 \mathrm{Hr}$ & $910 \mathrm{Hr}$ & \\
\hline Current Density, amp/sq ft & 33 & 33 & 33 & 33 & 33 \\
\hline Time in Operation, hours & 300 & 1100 & 100 & $910^{\circ}$ & 960 \\
\hline Total Cell Voltage, volts & 2.38 & 2.40 & 2.60 & 2.57 & 2.63 \\
\hline $\begin{array}{l}\mathrm{E}_{\text {ol }} \text {, Theoretical Cell-Decomposition } \\
\text { Voltage, volts }\end{array}$ & 1.23 & 1.23 & 1.23 & 1.23 & 1.23 \\
\hline $\begin{array}{l}\mathrm{E}_{\text {ta }} \text {, Total Cell-Activation Polarization, } \\
\text { volt }\end{array}$ & 0.02 & 0.04 & 0.03 & 0.04 & 0.05 \\
\hline $\begin{array}{l}\mathrm{E}_{\mathrm{tc}}, \text { Total Cell-Concentration } \\
\text { Polarization, volt }\end{array}$ & 0.97 & 0.98 & 0.99 & 0.95 & 1.01 \\
\hline $\mathrm{E}_{\text {IR }}$, Total Cell Ohmic Polarization, & $0.16(d)$ & $0.15(d)$ & $0.35(d)$ & $0.35(d)$ & $0.34(\mathrm{e}$ \\
\hline Matrix Thickness, mils & 20 & 20 & 53 & 53 & 53 \\
\hline
\end{tabular}
(a) Current-interruption technique was used.
(b) See text of report for cell details and other operating conditions.
(c) Slight changes of about \pm 0.02 volt in cell voltage occurred during the course of making the voltage-analysis run; thesc changes were not enough to affect the overall cell analysis significantly.
(d) These values include some IR drop in the cell leads; see also footnote (e).
(e) This value includes 0.13 volt of IR drop in cell leads. 
Current-Voltage Method. Table 7 shows the voltage characteristics of experimental cells as obtained from current/voltage curves during extended operational tests. In general, the voltage characteristics were similar as might be expected because of the similarity of the electrodes/matrix combination and the uniform testing conditions.

Figure 10 shows the voltage characteristics of Cell 3 at 1074 hours. More data points than usual for a current/voltage curve were used to prove by trial and error that there was a value of $E_{I R}$ for which $E^{\prime}=E-E_{I R}$ is a straight line (dashed line in figure 10). Approximate values of the polarization components at $33 \mathrm{amp} / \mathrm{ft}^{2}$ are illustrated in figure 10.

The data for Cell $4 \mathrm{~b}$ (table 7) is considered the more accurate and representative of experimental vapor cell operation based on selected data which excludes mechanical cell problems [footnote (b), table 7] and includes correction for IR loss in the leads [footnote (c), table 7].

Experimental Cell Performance

The detailed discussion of performance of each experimental cell does not appear needed herein in the light of the more recent results with the laboratory model unit presented later in this report. Only the essential results which contribute to the overall understanding of vapor cell operation are summarized for each experimental cell.

Cell 1. This special cell unit (16 in. ${ }^{2}$ ) available from prior NASA studies was evaluated first in the hope of providing a base line and tie-in with prior studies. Unfortunately, the large amount of acid used (by initial impregnation of the matrix with 96 percent $\mathrm{H}_{3} \mathrm{PO}_{4}$ ) proved to be excessive for the operating conditions.

Extreme flooding of the cell occurred with loss of electrolyte from the matrix; some of the electrolyte was found in the air outlet lines. The initial cell voltage was $2.65 \pm 0.05$ volts but increased to a value of $3.2 \pm 0.2$ volts. The run was terminated after 23 hours because the performance and cell voltage was not representative.

The problem of initial acid impregnation in relating to "flooding" is discussed further in Appendix B. Prior studies had indicated a value $24.7 \mathrm{~g}$ $\mathrm{P}_{2} \mathrm{O}_{5} /$ in. 3 of matrix volume for initial impregnation; even the reduced value of $15.3 \mathrm{~g} \mathrm{P}_{2} \mathrm{O}_{5} /$ in. 3 actually used for Cell 1 proved to be too much. A value of 9.5 to $10 \mathrm{~g} \mathrm{P}_{2} \mathrm{O}_{5} /$ in. $^{3}$ was used for Cells 3 and $4 \mathrm{~b}$ with no external 
TABLE 7. VOLTAGE CHARACTERISTICS OF EXPERIMENTAL CELLS AS OBTAINED FROM CURRENT/VOLTAGE CURVES AND EXPRESSED AS A CELL-VOLTAGE EQUATION(a)

\begin{tabular}{|c|c|c|c|c|c|c|c|}
\hline \multirow[b]{3}{*}{ Cell } & \multirow{3}{*}{$\begin{array}{c}\text { Operational } \\
\text { Hours }\end{array}$} & \multicolumn{3}{|c|}{ Cell Voltage, volts } & \multicolumn{3}{|c|}{ Constarits for } \\
\hline & & \multirow{2}{*}{$\begin{array}{c}32.8 \text { ASF } \\
E_{1}\end{array}$} & \multirow{2}{*}{$\begin{array}{c}10 \text { ASF } \\
\mathrm{E}_{2}\end{array}$} & \multirow{2}{*}{$\begin{array}{c}1 \text { ASF } \\
E_{3}\end{array}$} & \multicolumn{3}{|c|}{$E=a+b \log i+c i$} \\
\hline & & & & & $a$ & $\mathrm{~b}$ & c \\
\hline \multirow[t]{2}{*}{2} & 762 & 2. 420 & 2.190 & 1.960 & 1.954 & 0.176 & 0.0060 \\
\hline & 1100 & 2. 365 & 2. 175 & 1.960 & 1.956 & 0.178 & 0.0041 \\
\hline \multirow[t]{3}{*}{3} & 500 & 2.580 & 2. 228 & 1.968 & 1.957 & 0.157 & 0.0114 \\
\hline & 900 & 2.590 & 2.262 & 2.035 & 2.024 & 0.126 & 0.0112 \\
\hline & 1074 & 2.600 & 2.301 & 2.027 & 2.018 & 0.196 & 0.0087 \\
\hline \multirow[t]{6}{*}{$4 b(b, c)$} & 1 & 2.458 & 2. 118 & 1.876 & 1.865 & 0.139 & 0.0114 \\
\hline & 287 & 2. 462 & 2. 180 & 1.965 & 1.956 & 0.130 & 0.0094 \\
\hline & 448 & 2. 439 & 2. 179 & 1.955 & 1. 947 & 0.154 & 0.0078 \\
\hline & 695 & 2. 489 & 2. 209 & 1. 982 & 1.973 & 0.148 & 0.0088 \\
\hline & 866 & 2. 451 & 2. 200 & 1.983 & 1.975 & 0.147 & 0.0078 \\
\hline & 1123 & 2.531 & 2. 252 & 2.029 & 2.020 & 0.140 & 0.0092 \\
\hline
\end{tabular}

(a) Experimental cells were operated with an inlet air of $85 \mathrm{~F}, 50 \% \mathrm{RH}\left(0.013 \mathrm{lb} \mathrm{H}_{2} \mathrm{O} / \mathrm{lb} \mathrm{DA}\right)$ with an air flow of $0.048 \mathrm{ft}^{3} / \mathrm{min}(\mathrm{n}=4)$ Estimated steady-state electrolyte concentration of $75-80$ percent $\mathrm{H}_{3} \mathrm{PO}_{4}$ at about $90 \mathrm{~F}$

(b) During the operation of Cell $4 \mathrm{~b}$, difficulty was encountered in maintaining the air baffle in good contact with the anode as evidenced by an increase in cell voltage. When the cell was pressed together the voltage returned to normal (from 2.59 to 2.44 volts at 435 hours and from 2.61 to 2.45 volts at 865 hours).

(c) At 1123 hours for Cell 4b, the cell-voltage measurement was made as close as possible to the cell electrodes so as to minimize the voltage drop in the leads included in the cell-voltage measurement (i.e., measured cell voltage was lowered 0.13 volt at $32.8 \mathrm{amp} / \mathrm{ft}^{2}$ ). All data for Cell $4 \mathrm{~b}$ in table 7 prior to 1120 hours have been corrected to reflect true cell voltages. 


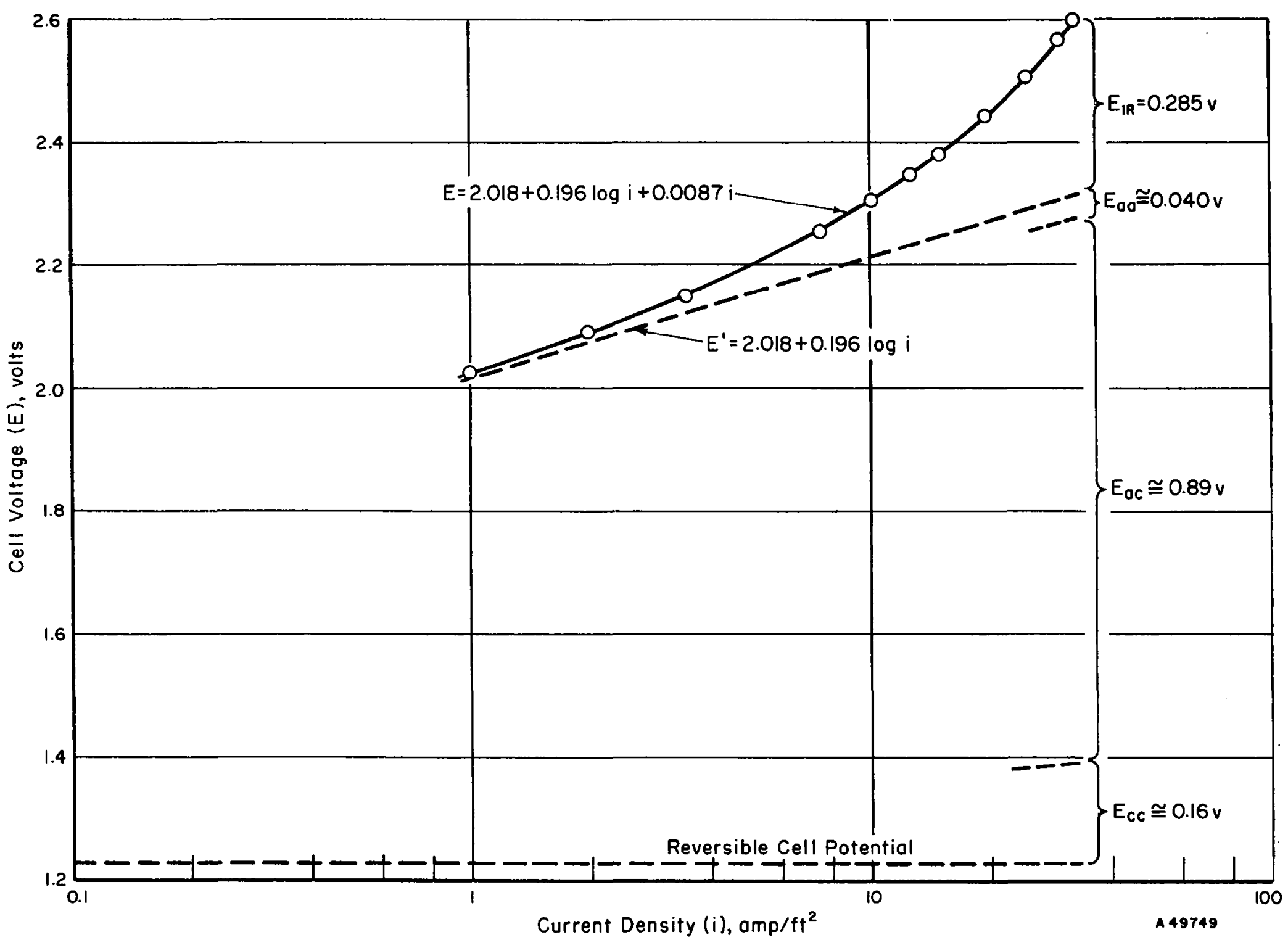

FIGURE 10. VOLTAGE CHARACTERISTICS FOR CELL 3 AT 1074 HOURS 
evidence of "flooding" for the steady-state conditions of extended testing. As will be shown later in this report, the optimum initial acid impregnation is dependent on the operating conditions to be used.

Cell 2. The distinctive feature of Cell 2 was the thinner matrix of two layers of asbestos (the usual 0.033 -inch-thick microporous rubber layer was omitted). The absence of the microporous rubber did not affect the voltage characteristics of the cell in any unexpected way. The cell voltage was about 0.2 volt lower than comparable cells because of the thinner matrix and the effect was reflected in the measurements of ohmic polarization as shown in table 6 and the constant $c$ in the voltage equation (table 7).

During 1300 hours of continuous operation, Cell 2 exhibited stable voltage characteristics. A comparis on of the initial steady-state voltage with the voltage at 1300 hours indicated $2.40 \pm 0.05$ volts for $32.8 \pm$ $0.4 \mathrm{amp} / \mathrm{ft}^{2}$.

The results relating to stability of the platinized-platinum electrodes and matrix were the same as the results for Cell 3 discussed below.

Cell 3. During 1100 hours of continuous operation, Cell 3 also exhibited stable voltage characteristics. Except for deviations caused by experimental equipment problems, the cell voltage was $2.60 \pm 0.05$ volt. Voltage-analysis results shown in table 6 confirm that the various component polarizations remained essentially the same during the extended operating period. Specifically, there was only a small increase in activation polarization, indicating that the platinizing of the electrodes was still partially effective. The results of visual inspection of the electrodes was more indicative of the limitations on extrapolation of the results beyond the operational test period.

Figure 10, shown earlier, is a typical voltage-characteristics curve obtained for Cell 3 at 1074 hours. The approximate distribution of polarization components is also shown based on the voltage-analysis results by the current-interruption method.

Cell 3 and Cell 2 were disassembled for inspection and the matrix appeared satisfactory. Some of the platinizing was off the anodes (about 30 percent of a central area on the screen was bright platinum). Some of the platinized platinum was on the matrix; some on the air baffle. The cathode screen appeared the same as when the cell was assembled. There was a definite difference between the cathode and anode but the effect might be a reduction in adhesion of platinized platinum to the anode. However, anodic 
oxidation of the platinized platinum and solution in phosphoric acid over a long period of time at room temperature would not be unexpected since platinized platinum is not anodically stable at high temperatures (i. e., $140 \mathrm{C}$ ). The practical result that no appreciable increase in cell voltage occurred for 1000 hours is good. However, in view of the visible observations and until further information is available, it would not be desirable to extrapolate the voltage performance beyond about 1300 hours with the available data.

Based on the voltage analysis results shown previously in table 2, at most, complete loss of platinizing at the anode (to bright platinum screen) would increase the cell voltage about 0.12 volt. The reduction in activation polarization of 0.13 volt achieved at the cathode by platinizing is probably permanent.

There was no visible evidence of physical or chemical deterioration of the matrix (particularly the asbestos in contact with the anode). From the voltage characteristics, there was no evidence that the matrix adversely affected vapor absorption or establishment of a representative steady-state electrolyte concentration. Since voltage-analysis results showed that comparable concentration polarization values could be obtained with a free electrolyte, there was no reason to expect that the matrix (asbestos/platinizedplatinum screen electrode combination) adversely affected the cell voltage either directly (gas polarization) or indirectly (mass transfer and steadystate electrolyte concentration at the anode surface). Subsequent theoretical analysis of mass transfer of water vapor to the matrix supports the contention that the physical properties of the asbestos used or the dimensional configuration of the screen electrode used did not affect the steady"state electrolyte concentration and cell voltage.

In view of the above results, study of various matrix materials was eliminated as a subject of immediate concern. Similarly, the use of platinized-platinum screen electrodes and the design of the fluted plastic baffle providing the air channel were shown to be adequate for 1000-hour tests. These design features were fixed for subsequent experimental cells and the laboratory model in order to concentrate on the other system variables.

Cell 4b. Cell 4b was the first experimental cell that incorporated the new cell design features that were being developed on the program. In all significant aspects Cell $4 \mathrm{~b}$ was a prototype of the cell design used in construction of the laboratory model.

Hydrogen-gas volume collections were made during the operation of Cell $4 \mathrm{~b}$ at 287,840 , and 1195 hours, and the rate of hydrogen-gas collection 
was $>99$ percent of the theoretical rate (which is within the accuracy of the ammeter used). Analysis of the collected hydrogen indicated $>99.7$ percent hydrogen. The result indicated the effectiveness of cell sealing that was absent for Cell 3 and, more important, established that the standard matrix combination used prevented cross leak of gases (air leaving cell contained less than 0.005 percent hydrogen).

The use of 80-mesh, 3-mil wire for the platinized-platinum electrodes for the first time in Cell $4 \mathrm{~b}$ gave good voltage characteristics as shown in table.7. A comparison of cell voltage of Cell $4 \mathrm{~b}$ with Cell 3 with different electrodes (45-mesh, 7.8-mil wire) might not be valid since no correction was applied to data for Cell 3 for possible voltage drop in the leads [ see footnote (c), table 7]. Regardless, the 80-mesh screen electrodes are favored for weight and cost reduction.

At 865 hours, the anode of Cell $4 \mathrm{~b}$ was examined and looked good. No bright platinum was observed. Voltage analysis at 960 hours indicated a total activation polarization of 0.05 volt (table 6) which was slightly higher than usual. The values of the constant "a" in the cell-voltage equation for Cell 4b (table 7) show a gradual increase through 1123 hours which might indicate some loss of effect of platinizing. During the period of continued operation from 1200 to 1380 hours, the cell voltage was fairly constant at $2.54 \pm 0.01$ volt. Unfortunately, the operation of Cell $4 \mathrm{~b}$ was terminated at 1380 hours by an unusual failure of the water-temperature control circuit of the air conditioning unit which cáused abnormal conditions in the air circulating system (saturated air at up to $160 \mathrm{~F}$ and possibly condensed water entered the cell air inlet). In spite of the abnormal cell flooding, examination of the anode showed that 80-90 percent of the anode screen had platinized platinum on it.

In general, the results with Cell $4 \mathrm{~b}$ and Cells 2 and 3 lead to the conclusion that the beneficial effects of platinizing the anode can be maintained for at least 1000 hours for the operating conditions of the experimental cells, principally the low electrolyte temperature $(\sim 90 \mathrm{~F})$. Further study to improve platinizing procedure or similar treatment for the anodes to reduce activation polarization appears necessary to greatly extend the operating time beyond 1000 hours. Stability of the platinized cathodes does not appear to be a problem. The subsequent evaluation of the laboratory model which was effectively insulated and operated at higher electrolyte temperatures provided a more severe test of electrode stability.

When Cell 4b was examined at 865 hours of operation, there was visible evidence of acid spray on the inside of the gooch rubber tubing used on the air-oxygen outlet (figure $7 \mathrm{a}$ ). The tubing had some small holes or tears in it, indicating attack by either acid or ozone or both. The amount of acid 
loss by spray (probably aerosol of electrolyte formed by exploding oxygen bubbles) does not appear large enough to significantly affect cell operation. However, acid spray is recognized as a potential contaminant of the air stream recirculated to the cabin and means would have to be provided to purify the air if acid spray is a real problem. The observations of acid spray with the experimental cells were not considered conclusive and further evidence obtained with the laboratory model suggests that acid spray might not be a problem when the full knowledge of vapor-cell operation is applied to selection of the optimum initial acid impregnation.

The evidence of ozone in the outlet air stream by attack on rubber tubing was similar to the observation first made in prior studies (ref. 1) that ozone can be formed in vapor cells. No specific analysis was made during this study to identify the concentration of ozone since analysis for small amounts of ozone (probably in the parts per million range or less) is difficult and might have been premature until the efforts toward voltage reduction on the vapor cell had defined the optimum voltage. The amount of ozone produced is probably related to the degree of polarization of the anode; the polarization is usually high enough for ozone formation with concentrated acids. At the present time ozone formation is not considered a serious problem with the vapor cell since ozone is a relatively unstable compound that can be reduced to oxygen in a subsequent treatment of the air before return to the cabin. Actually, ozone production in the electrolysis cell acting on all the cabin air as a purifier of other air-borne contaminants could be an important incidental advantage of the vapor cell.

Measurement of the temperature of the air leaving Cell $4 \mathrm{~b}$ indicated a temperature rise of only $3 \mathrm{~F}$ (only about 10 percent of the cell heat was removed by the air stream). Based on the actual temperature rise of the air, the electrolyte temperature at the anode/matrix interface was estimated to have been about $90 \mathrm{~F}$. The latter temperature is the important factor in evaluating the observed voltage characteristics. In a later section of this report on "Analysis of Experimental Cell $4 \mathrm{~b}$ Performance", the voltage characteristics of Cell 4b at 1123 hours (table 7) and the operating conditions for experimental cells are analyzed with respect to heat transfer and mass transfer. The estimates of the steady-state electrolyte concentration and temperature in the matrix are close to the preferred values for vapor-cell operation. Thus, the good operational performance of Cell $4 \mathrm{~b}$ might be considered more representative of a vapor cell than the results with the laboratory model. 
Summary of 300-Hour Continuous Operation Test. The laboratory model consisted of a battery of ten experimental cells connected in series electrically. Each cell was fabricated individually with a design similar to Experimental Cell 4b and later assembled into a battery. Figure 6 shows the laboratory model which had overall dimensions of 2.1 by 2.1 by 1.5 inches $\left(0.004 \mathrm{ft}^{3}\right)$ and weighed 0.33 pound. The oxygen-production capacity of the laboratory model is dependent on the operating current density, but a typical value is $1 / 25-$ man capacity (about $0.081 \mathrm{lb} \mathrm{O}_{2} /$ day) for 23 volts and 0.5 ampere $\left(18 \mathrm{amp} / \mathrm{ft}^{2}\right)$.

A total of 342 hours of satisfactory operation has been obtained with the laboratory model up to the end of the period covered by this report. Table 8 shows data representative of steady-state electrolysis after various periods of operation.

The insulating fixture in which the laboratory model was positioned for experimental evaluation was shown in figure 7 to identify the location of the thermocouples (TC) which provided the temperature readings shown in table 8. Reliable readings of the important air outlet temperature were obtained for the first 100 hours of operation and these data were sufficient for the calculations presented later under "Analysis of Laboratory Model Performance".

Continuous operation was obtained from 14 to 342 hours. Malfunctions in the experimental control circuit caused a 16-hour interruption after the first $1 / 2$ hour of operation and an 8-hour interruption after a total of 14 hours of operation. A current density of about $16 \mathrm{amp} / \mathrm{ft}^{2}$ was maintained from 5 to 14 hours. From 20 to $69-1 / 2$ hours the voltage of the battery of cells in series was set to obtain a current density of $21.5 \mathrm{amp} / \mathrm{ft}^{2}$. A current/voltage curve was obtained after 68-1/2 hours. At 69-1/2 hours, the voltage of the battery of cells in series was reduced to $22.6 \pm 0.1$ volt for the remainder of the operational test and the current density was $16.3 \pm$ $0.6 \mathrm{amp} / \mathrm{ft}^{2}$ for over 300 hours.

Voltage Characteristics. The current/voltage curves shown in figure 11 were obtained after the data were taken for $68-1 / 2$ hours in table 8 . A 48-hour period at about $21.5 \mathrm{amp} / \mathrm{ft}^{2}$ preceded the current/voltage curve and the voltage characteristics in figure 11 are representative of the steadystate conditions at $21.5 \mathrm{amp} / \mathrm{ft}^{2}$ (electrolyte concentration and temperature in the matrix). The outlet air temperature of $119 \mathrm{~F}$ decreased only $1 \mathrm{~F}$ when the current density was lowered to $10 \mathrm{amp} / \mathrm{ft}^{2}$ and then $1 \mathrm{amp} / \mathrm{ft}^{2}$ and then 
TABLE 8. SUMMARY OF PERFORMANCE OF LABORA TORY MODEL UNIT DURING FIRST 300 HOURS OF OPERA TION

\begin{tabular}{|c|c|c|c|c|c|c|c|}
\hline Total Operating Time, hours & 12 & 21 & $68-1 / 2$ & $95-1 / 2$ & $187-1 / 2$ & 260 & $306-1 / 2$ \\
\hline Current Density, amp/ $\mathrm{ft}^{2}$ & 16.1 & 21.5 & 21.5 & 16.9 & 16.4 & 16.7 & 15.7 \\
\hline Battery Voltage, volts & 23.32 & 23.40 & 23.18 & 22.68 & 22.50 & 22.73 & 22.69 \\
\hline \multicolumn{8}{|l|}{ Cell Voltages, volts } \\
\hline$B_{1}$ & 2.37 & 2.39 & 2.42 & 2.31 & 2.29 & 2.29 & 2.28 \\
\hline $\mathrm{B}_{2}$ & 2.31 & 2.32 & 2.29 & 2.25 & 2.24 & 2.27 & 2.28 \\
\hline $\mathrm{B}_{3}$ & 2.31 & 2.32 & 2.30 & 2.25 & 2.22 & 2.22 & 2.20 \\
\hline $\mathrm{B}_{4}$ & 2.32 & 2.33 & 2.31 & 2.27 & 2.28 & 2.26 & 2.25 \\
\hline $\mathrm{B}_{5}^{4}$ & 2.30 & 2.30 & 2.27 & 2.23 & 2.22 & 2.22 & 2.22 \\
\hline $\mathrm{B}_{6}$ & 2.33 & 2.31 & 2.28 & 2.24 & 2.24 & 2.26 & 2.26 \\
\hline $\mathrm{B}_{7}$ & 2.32 & 2.33 & 2.29 & 2.25 & 2.26 & 2.32 & 2.33 \\
\hline $\mathrm{B}_{8}$ & 2.30 & 2.32 & 2.29 & 2.25 & 2.24 & 2.26 & 2. 26 \\
\hline $\mathrm{B}_{9}$ & 2.37 & 2.37 & 2.33 & 2.28 & 2.27 & 2.28 & 2.27 \\
\hline $\mathrm{B}_{10}$ & 2.38 & 2.40 & 2.39 & 2.34 & 2.33 & 2.34 & 2.33 \\
\hline \multicolumn{8}{|l|}{ Temperatures, $\mathrm{F}$} \\
\hline A ir Inlet & 85.5 & 85.0 & 84.5 & 84.5 & 85.0 & 85.0 & 84.8 \\
\hline A ir Outlet & 112 & 118 & 119 & 112 & \multicolumn{3}{|c|}{ (thermocouple failed) } \\
\hline Hydrogen Outlet (TC5) & 102 & 104 & 104 & 102 & 99 & 101 & 99 \\
\hline Top of Battery (TC3) & 99 & 101 & 102 & 99 & 96 & 97 & 97 \\
\hline Bottom of Battery (TC4) & 97 & 99 & \multicolumn{5}{|c|}{ (thermocouple failed) } \\
\hline Air Flow $(\mathrm{q}), \mathrm{ft}^{3} / \mathrm{min}$ & 0.53 & 0.53 & 0.53 & 0.53 & 0.53 & 0.53 & 0.53 \\
\hline Inlet Humidity $\left(\mathrm{h}_{1}\right), \mathrm{lb}_{2} \mathrm{O} / \mathrm{lb} \mathrm{DA}$ & 0.0129 & 0.0130 & 0.0130 & 0.0130 & 0.0130 & 0.0130 & 0.0129 \\
\hline n (Calculated) & 8.9 & 6.7 & 6.7 & 8.5 & 8.8 & 8.6 & 9.1 \\
\hline
\end{tabular}




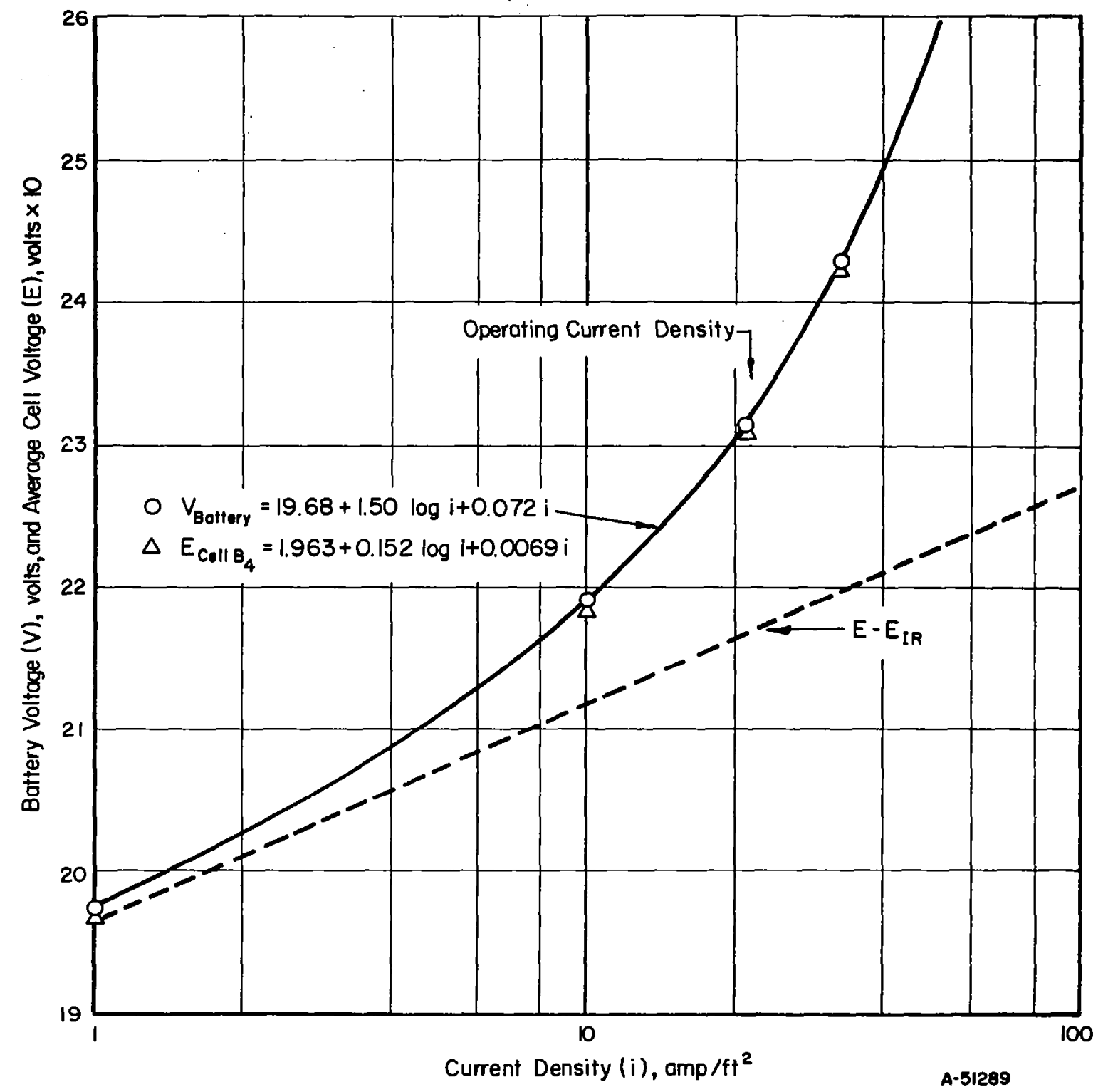

FIGURE 11. VOLTAGE CHARACTERISTICS OF LABORATORY MODEL BATTERY OF TEN CELLS IN SERIES

Data obtained after 48 hours at $21.5 \mathrm{amp} / \mathrm{ft}^{2}$; 68-1/2 hours total operation. 
increased to $32.8 \mathrm{amp} / \mathrm{ft}^{2}$. The battery voltage was measured on a Millivac voltmeter and simultaneously the voltage of Cell $\mathrm{B}_{4}$ was measured on a digital voltmeter.

The voltage characteristics of the battery of cells were similar to the voltage characteristics of a single cell $\left(\mathrm{Cell} \mathrm{B}_{4}\right)$ which had a voltage close to the average voltage of cells in the battery. I However, individual cells of the battery varied in voltage from 2.27 volts to 2.42 volts compared to the average of 2.32 volts at $21.5 \mathrm{amp} / \mathrm{ft}^{2}$, table 8 . The voltage equation was calculated from the values at 1,10 , and $32.8 \mathrm{amp} / \mathrm{ft}^{2}$.

$$
\begin{aligned}
V_{B} & =19.68+1.50 \log i+0.072 i \\
E_{B_{4}} & =1.963+0.152 \log i+0.069 i
\end{aligned}
$$

The above equations were used to calculate the voltage at $21.1 \mathrm{amp} / \mathrm{ft}^{2}$ (the current density immediately preceding and following the current/voltage curve) which compared well with the actual measured voltages at

\begin{tabular}{|c|c|c|}
\hline & $\mathrm{V}_{\mathrm{B}}$, volts & $\mathrm{E}_{\mathrm{B}_{4}}$, volts \\
\hline Initial & 23.15 & 2. 314 \\
\hline Final & 23.13 & 2. 313 \\
\hline Calculated & 23.17 & 2.309 \\
\hline
\end{tabular}
21. $1 \mathrm{amp} / \mathrm{ft}^{2}$ :

After obtaining the current/voltage curve, the battery voltage was reduced for the remainder of the operational test to $22.6 \pm 0.1$ volt. The current density of $16.3 \pm 0.6 \mathrm{amp} / \mathrm{ft}^{2}$ for over 300 hours indicated that there was very little change in battery voltage characteristics relative to the curve in figure 11 for operation at the lower current density.

Series Operation of Cells in a Battery. An important purpose of the evaluation of the laboratory model was to observe the individual cell performance in a series-connected battery. When only a single vapor cell is operated at constant voltage, there is a large degree of self-corrective action so that the cell seeks a steady-state condition. The current can automatically adjust to compensate for changes in electrolyte concentration caused by changes in water-vapor absorption. However, a single cell in a battery operated at constant voltage operates at the current dictated by the total resistance of all the cells in the battery and cannot correct easily for any unusual vapor absorption conditions peculiar to that cell. For example, a below-average air flow rate through a single cell of the battery could lead to drying out of the matrix. This would tend to increase the individual cell voltage and temperature which would compound the original problem and 
lead to failure of a single cell and thus the whole battery. For this reason, fairly uniform distribution of air flow among the cells of a battery is necessary.

The results of series cell operation of the laboratory model were fairly good as shown by the individual cell voltages tabulated in table 8 . There was a tendency of centrally located cells to operate at lower voltage than end cells. The higher voltage of end cells is believed to be associated with lower temperature at the ends of the battery. The difference in voltage between the lowest and highest cell voltages was 0.080 volt at the start (12 hours, table 8) and varied from 0.10 to 0.15 volt during the test. During the last 200 hours of operation at $16-17 \mathrm{amp} / \mathrm{ft}^{2}$ shown in table 8 , the cell voltage for each cell tended to stabilize. The exception is Cell $\mathrm{B}_{7}$ where the gradual increase in cell voltage could be indicative of the loss of platinizing from the anode. However, this was not verified by visual examination of the electrodes.

Hydrogen Collection. Several times during the test of the laboratory model measurement of hydrogen collection rate indicated about 90-92 percent of the theoretical rate. In view of the good results reported with Experimental Cell 4b, cross leakage of hydrogen through the matrix would not be expected for a similar matrix used in the cells of the laboratory model. Since each cell had been checked for edge-sealing leaks before assembly of the battery, it is suspected that the loss of hydrogen was occurring at the hydrogen manifold attachment to the side of the battery. The method of hydrogen collection from the cells of the battery is the weakest part of the design and improvement is needed for future models.

Electrolyte Loss as Spray. The clear Lucite container at the air outlet from the cells (figure 7) was provided for visual observations of any acid spray from the cells of the laboratory model. A piece of blue litmus paper positioned in the air outlet became red during the first hour of operation. However, this indication of acid spray was not considered representative. Some difficulty was encountered in start-up because the cells had picked up water between the time of initial acid impregnation during assembly and the start of the test. Bubbling of the electrolyte at the anode screen could be seen near the air outlet of the cells. Since the cells could not be electrolyzed without air flow which would have caused excessively high cell temperature, the humidity of the air to the cells was reduced until the excess water was electrolyzed. When normal voltage characteristics were obtained, the humidity was increased to the test condition. During this start-up period, some acid spray had collected on the inside of the Lucite chamber at the air outlet. 
No further acid spray was collected during the period of operation at $21.5 \mathrm{amp} / \mathrm{ft}^{2}$. However, after about 100 hours of operation at the reduced current density of $16-17 \mathrm{amp} / \mathrm{ft}^{2}$, there was evidence that the amount of acid spray on the Lucite chamber was increasing. Some acid was observed to have settled out in a sharp bend of the air outlet tubing connected to the Lucite chamber.

During the 342 hours of operation, it is estimated that the total amount of acid lost from the cell as spray amounted to $0.1 \mathrm{~cm}^{3}(2-3 \mathrm{drops}) \mathrm{com}$ pared to a total $20 \mathrm{~cm}^{3}$ of acid originally used for impregnation of all cells of the battery. The loss of acid as spray would probably cease when the excess for the steady-state operating conditions had been lost from the matrix. The indication that there was no visible effect of acid spray at the higher current density suggests that there is a steady-state electrolyte concentration at which acid loss is minimum (a relatively dry matrix) while maintaining satisfactory voltage characteristics. The problem resolves to a correct initial acid impregnation for the steady-state conditions that will exist. The observations thus far are considered inconclusive as to whether acid spray loss is an inherent problem of vapor-cell operation that would necessitate subsequent treatment of the air stream. Further study is needed of extended operation of cells that have received a more optimum initial acid impregnation based on calculations discussed later under "Preferred Operating Conditions for Vapor Cell".

\section{DISCUSSION OF VAPOR CELL DESIGN AND OPERATION}

\section{Correlation of Theory and Cell Operational Results}

$\underline{\text { Introduction }}$

An important result of the present study is the better understanding of the operation of a vapor cell. This has been accomplished by derivation of theoretical equations which show the quantitative relationship of the principal variables involved in cell design and operation. The detailed derivations covered in Appendix $C$ of this report are directed to generalized expressions for three important quantities:

(1) The electrical power $\left(P_{f}\right)$ required for flow of cabin air through the vapor cell based on the theory of fluid dynamics 
(2) The steady-state temperature $\left(T_{m}\right)$ of the electrolyte in the matrix based on heat-transfer theory

(3) The steady-state humidity $\left(h_{m}\right)$ that would be in equilibrium with the phosphoric acid in the matrix based on masstransfer theory.

Item ( 1 ) is a principal determinant of the physical cell design and operational limits for cabin air flow recirculation rates. Items (2) and (3) taken together define the steady-state concentration of phosphoric acid in the matrix; the latter being the principal determinant of the voltage characteristics (concentration polarization and ohmic polarization).

The theoretical equations appear to be consistent with the observed performance of the vapor cell and the use of the equations with specific operational data will be shown. Finally, the new knowledge which forms a working hypothesis will be used to predict a preferred set of operating conditions for the vapor cell which can be subjected to experimental verification in future extended operational runs.

\section{Analysis of Laboratory Model Performance}

Fluid Dynamics. The specific data shown in table 8 for $68-1 / 2$ hours of operation were used in the first set of calculations with the appropriate equations from Appendix $C$ indicated by the equation number in the right margin. Uniform distribution of air flow among the 10 equivalent cells was assumed and a single cell ( 2 by 2 inch) can be considered for the calculation of the important operational parameter " $n$ " from measured values.

The measured inlet air temperature $\left(\mathrm{T}_{1}\right)$ was $84.5 \mathrm{~F}$ and the inlet air humidity $\left(\mathrm{h}_{1}\right)$ was $0.013 \mathrm{lb} \mathrm{H}_{2} \mathrm{O} / 1 \mathrm{~b} \mathrm{DA}$ (from psychometric chart based on dew-point measurement). The specific barometric pressure (P) was not measured and normal atmospheric pressure (760 mm Hg) was assumed for calculation of the specific volume $(v)$ of the moist inlet air:

$$
\begin{aligned}
& v=\frac{19.15\left(\mathrm{~T}_{1}+460\right)}{\mathrm{P}}\left[1+16.08\left(\mathrm{~h}_{1}\right)\right] \\
& v=14.0 \mathrm{ft}^{3} / \mathrm{lb} \mathrm{DA} .
\end{aligned}
$$


The current density (i) of $21.5 \mathrm{amp} / \mathrm{ft}^{2}$ can be converted to current (I) [ the value measured] for the effective electrolysis cell dimensions of length (L) of 2.0 inches and width (W) of 2.0 inches:

$$
\begin{aligned}
& I=\frac{i(L)(W)}{144} \\
& I=0.60 \text { ampere. }
\end{aligned}
$$

The air flow per cell ( $\left.\mathrm{q}^{\prime}\right)$ was $0.053 \mathrm{ft}^{3} / \mathrm{min}$ and using the above values the relative air flow ( $n$ ) was:

$$
\begin{aligned}
& \mathrm{n}=\frac{81,300\left(\mathrm{q}^{\prime}\right)\left(\mathrm{h}_{1}\right)}{(\mathrm{v})\left(\mathrm{I}^{\prime}\right)} \\
& \mathrm{n}=6.7 .
\end{aligned}
$$

The Reynolds number $\left(\mathrm{N}_{\mathrm{Re}}\right)$ based on the inlet air temperature can be calculated for a kinematic viscosity $(\nu)$ of about $0.00016 \mathrm{ft}^{2} / \mathrm{sec}$ for air at $85 \mathrm{~F}$ :

$$
\begin{aligned}
& \mathrm{N}_{R e}=3.4 \times 10^{-8} \frac{(\mathrm{L})(\mathrm{i})(\mathrm{v})(\mathrm{n})}{\left(\mathrm{h}_{1}\right)(\nu)} \\
& \mathrm{N}_{\mathrm{Re}}=66 .
\end{aligned}
$$

Thus, the air flow is definitely laminar compared to the approximate criterion of $\mathrm{N}_{\mathrm{Re}} \cong 2000$ for turbulent flow. The above expression for Reynolds number indicates that within a practical range of values of the variables, attainment of turbulent flow is not likely (or necessary as shown later). The fact that the Reynolds number is below about 450 is pertinent to the validity of the theoretical equations based on heat transfer and mass transfer.

The average velocity (V) may be of interest although not directly pertinent to the calculations and was calculated to be $2.4 \mathrm{ft} / \mathrm{sec}$ using an alternate expression for the Reynolds number:

$$
N_{\operatorname{Re}}=\frac{b^{\prime} v}{6000(\nu)}
$$

where $\mathrm{b}^{\prime}=25.8 \mathrm{mil}$ (calculated in Appendix $\mathrm{C}$ to be the parallel-plate spacing that would be aerodynamically equivalent to the fluted air baffle used). 
The theoretical pressure drop $(\Delta P)$ for air flow through a cell (neglecting inlet and exit losses which are negligible for the low air velocity) is

$$
\begin{aligned}
& \Delta P=\frac{6.4(\nu)(i)(n)(L)^{2}}{\left(h_{1}\right)\left(b^{\prime}\right)^{3}} \\
& \Delta P=0.0026 \mathrm{psi} .
\end{aligned}
$$

Because of the small pressure drop, a solution of dibutylthalate $130 \mathrm{~mm}$ $\mathrm{DPT}=1$ inch water) was used in the manometer. The actual measured pressure drop across the cell was about $2 \mathrm{~mm}$ DPT $\cong 0.07$ inches $\mathrm{H}_{2} \mathrm{O} \cong$ 0.0026 psi.

The power $\left(P_{f}\right)$ required to flow air through a single cell for a conservative estimate of blower efficiency $(\eta)$ of 0.5 is

$$
\begin{aligned}
& P_{f}=1.8 \times 10^{-6}\left[\frac{(v)(\nu)}{\left(h_{1}\right)^{2}}\right]\left[\frac{(L)^{3}(W)}{\left(b^{\prime}\right)^{3}}\right]\left[\frac{(i)^{2}(n)^{2}}{\eta}\right] \\
& P_{f}=0.00092 \text { watt per cell } .
\end{aligned}
$$

Even an extrapolation to a one-man prototype unit (127 amperes equivalent) from 0.6 ampere/cell indicates a very low blower power of about 0.2 watt. Thus, future increase in relative air flow rate (i.e., $n$ value) over that used in the evaluation of the laboratory model appears feasible and desirable. The particular form of the above equation for blower power shows the effect of inlet air properties (first bracketed term), air-channel design (second term), and operational design variables (third term).

Heat Transfer. The theoretical temperature rise $\left(T_{A}\right)$ of the air stream passing through the cell can be calculated on the basis of no other heat loss and compared with the measured temperature rise. The specific heat $\left(C_{p}\right)$ for moist air was estimated for the inlet air humidity:

$$
\begin{aligned}
& \mathrm{C}_{\mathrm{p}}=0.24+0.45 \mathrm{~h}_{\mathrm{l}} \\
& \mathrm{C}_{\mathrm{p}}=0.246 \mathrm{Btu} / \mathrm{lb}-\mathrm{F} .
\end{aligned}
$$

The air outlet temperature depends on the individual cell voltages assuming uniform air flow to each cell. Since the thermocouple was located at the outlet of Cell $B_{5}$, the voltage of the latter cell is used $\left(E_{5}=2.27\right.$ volt from table 8). 


$$
\begin{aligned}
& \Delta T_{A}=\frac{4620(E-1.25)\left(h_{1}\right)}{\left(C_{p}\right) n} \\
& \Delta T_{A}=\frac{244.5\left(E_{5}-1.25\right)}{n} \\
& \Delta T_{A}=37.2 \mathrm{~F} .
\end{aligned}
$$

The theoretical outlet temperature should have been

$$
\mathrm{T}_{2}=84.5+37.2=121.7 \mathrm{~F}
$$

compared to the actual measured outlet temperature of $119 \mathrm{~F}$ $\left(\Delta \mathrm{T}_{\mathrm{A}}=34.5 \mathrm{~F}\right)$. Therefore, about $\frac{34.5}{37.2} \times 100=93$ percent of the heat generated in Cell $\mathrm{B}_{5} \mathrm{can}$ be accounted for in the air stream; the remainder was probably lost through the walls by conduction and convection.

For a more accurate estimate of the average electrolyte temperature in the matrix $\left(T_{m}\right)$, the actual temperature rise (rather than theoretical) was used:

$$
\begin{aligned}
& \mathrm{T}_{\mathrm{m}}=\mathrm{T}_{1}+1.75\left(\Delta \mathrm{T}_{\mathrm{A}}\right) \\
& \mathrm{T}_{\mathrm{m}}=145 \mathrm{~F} .
\end{aligned}
$$

The above value is believed to be reasonably accurate and better than $\pm 8 \mathrm{~F}$ based on extreme assumptions regarding heat-transfer surface as discussed in Appendix $C$. The value calculated for $T_{m}$ is an average value. Just as the air temperature increases from $84.5 \mathrm{~F}$ to $119 \mathrm{~F}$ from inlet to outlet, it is estimated that the electrolyte temperature gradient in the matrix might be as high as 128 to $162 \mathrm{~F}$ from air inlet to air outlet. Calculations in Appendix $C$ show that there is a negligible temperature gradient $(<1 F)$ across the matrix from anode to cathode. the outlet humidity is

Mass Transfer. For an inlet humidity $\left(\mathrm{h}_{1}\right)$ of $0.013 \mathrm{lb} \mathrm{H} \mathrm{H}_{2} \mathrm{O} / \mathrm{lb} \mathrm{DA}$,

$$
\begin{aligned}
& \mathrm{h}_{2}=\mathrm{h}_{1}-\frac{\mathrm{h}_{1}}{\mathrm{n}} \\
& \mathrm{h}_{2}=0.0111 \mathrm{~b} \mathrm{H} \mathrm{H}_{2} \mathrm{O} / \mathrm{lb} \mathrm{DA} .
\end{aligned}
$$


Estimates of the steady-state electrolyte concentration in the matrix can be obtained from theoretical equations derived from a consideration of mass transfer of water vapor. The humidity $\left(h_{m}\right)$ in equilibrium with the mean electrolyte concentration in the matrix at the anode is

$$
\begin{aligned}
& h_{m}=h_{1}\left(1-\frac{2}{n}\right) \\
& h_{m}=0.0091 b H_{2} O / 1 b D A .
\end{aligned}
$$

It is estimated that there is little difference in electrolyte concentration gradient between the anode and cathode. However, there probably is an electrolyte concentration gradient in the matrix from inlet to outlet. Assuming a constant driving force for mass transfer of vapor $\left(\Delta h_{m}\right)$ the value is

$$
\begin{aligned}
\Delta \mathrm{h}_{\mathrm{m}} & =1.5 \frac{\mathrm{h}_{1}}{\mathrm{n}} \\
\Delta \mathrm{h}_{\mathrm{m}} & =0.003 \mathrm{lb} \mathrm{H} \mathrm{H}_{2} \mathrm{O} / 1 \mathrm{~b} \mathrm{DA} .
\end{aligned}
$$

The humidity in equilibrium with the electrolyte concentration in the matrix varies from $0.010 \mathrm{lb} / \mathrm{H}_{2} \mathrm{O} / \mathrm{lb} \mathrm{DA}$ at the inlet to $0.008 \mathrm{lb} \mathrm{H}_{2} \mathrm{O} / \mathrm{lb} \mathrm{DA}$ at the outlet. Thus, the electrolyte concentration increases from inlet to outlet as does the temperature of the electrolyte. A knowledge of the mean temperature $\left(\mathrm{T}_{\mathrm{m}}\right)$ and humidity $\left(\mathrm{h}_{\mathrm{m}}\right)$ corresponding to the mean steady-state electrolyte concentration in the matrix is usually sufficient to understand operation of the vapor cell.

Steady-State Electrolyte Concentration. Figure 12 shows the watervapor pressure (p) in equilibrium with aqueous phosphoric acid solutions as a function of temperature [from data in ref. 5]. For easier use a Fahrenheit temperature scale has been provided as well as a humidity scale (1b $\mathrm{H}_{2} \mathrm{O} / 1 \mathrm{~b} \mathrm{DA}$ ) corresponding to the vapor pressure ( $\mathrm{p}$ ) for an assumed total pressure (P) of $760 \mathrm{~mm} \mathrm{Hg}$ :

$$
\mathrm{p}=\frac{1.6(\mathrm{P})\left(\mathrm{h}_{\mathrm{m}}\right)}{1+1.6\left(\mathrm{~h}_{\mathrm{m}}\right)}
$$

From figure 12, it is seen that the previous estimates of $h_{m}=0.0091 b \mathrm{H}_{2} \mathrm{O} /$ $1 \mathrm{~b} D A$ and $\mathrm{T}_{\mathrm{m}}=145 \mathrm{~F}$ correspond to an electrolyte concentration of about $90 \% \mathrm{H}_{3} \mathrm{PO}_{4}$. 


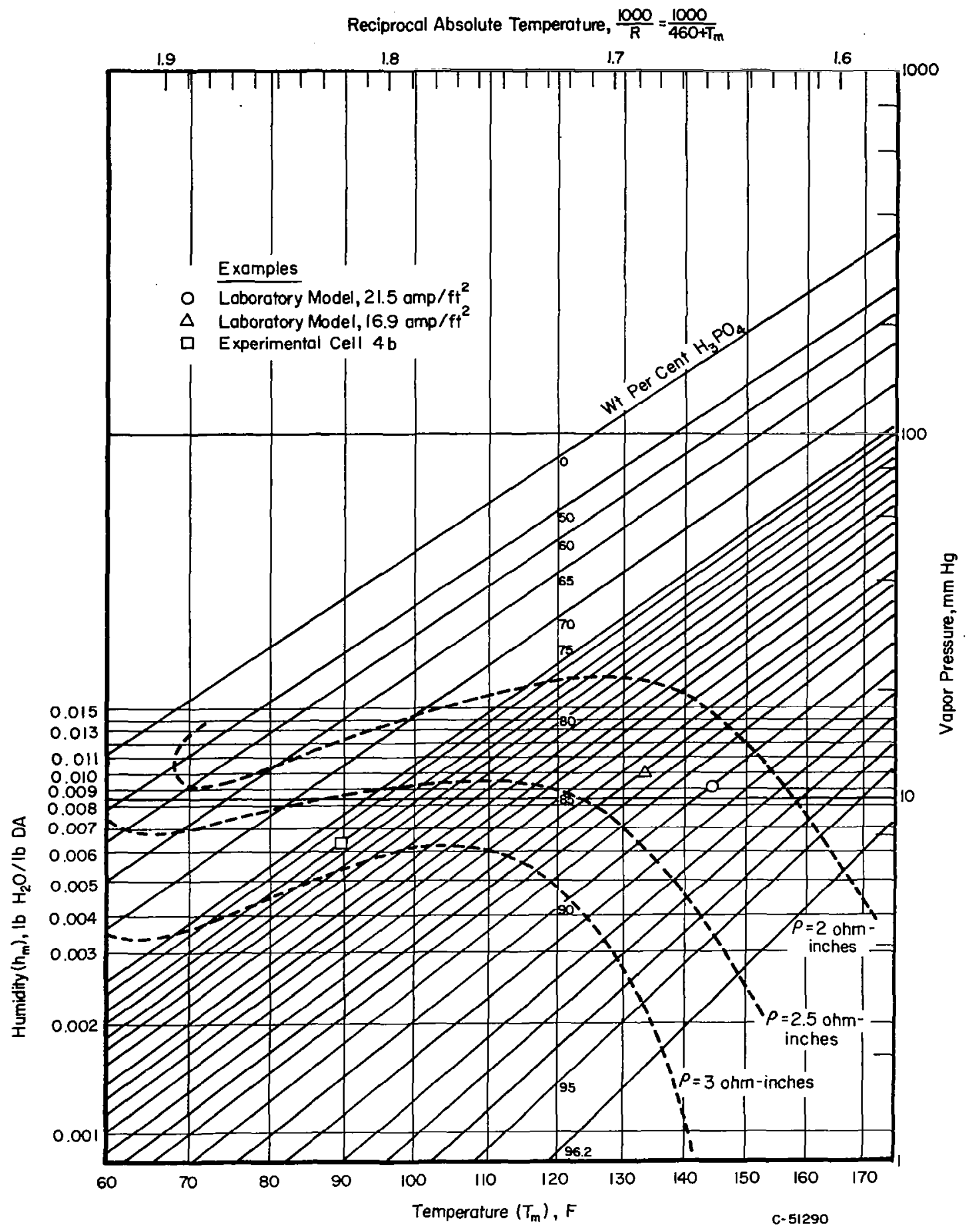

FIGURE 12. CHART FOR ESTIMA TING STEADY-STATE ELECTROLYTE CONCENTRATION 
Lines of constant specific resistance $(\rho)$ of the electrolyte for $2,2.5$, and $3 \mathrm{ohm}$-inches are also shown on figure 12. Thus, for a concentration of $90 \% \mathrm{H}_{3} \mathrm{PO}_{4}$ at $145 \mathrm{~F}, \rho=2.2 \mathrm{ohm}$-inches. The latter value can be used to estimate the ohmic polarization as was shown previously in a discussion of the current/voltage technique:

$$
\begin{aligned}
& c=\frac{t k \rho}{144} \\
& c=\frac{(0.053)(9)(2.2)}{144} \\
& c=(0.0033)(2.2)=0.007 \mathrm{ohm}-\mathrm{ft}^{2} .
\end{aligned}
$$

The above value of the constant "c" checks with voltage characteristics shown in figure 11 which represented steady-state conditions for a current density of $21.5 \mathrm{amp} / \mathrm{ft}^{2}$.

Effect of Lower Current Density. Similar calculations were made for the data in table 8 at 95-1/2 hours for a lower current density of $16.9 \mathrm{amp} /$ $\cdot \mathrm{ft}^{2}$. Since the air flow rate was the same $\left(\mathrm{q}^{\prime}=0.053 \mathrm{ft}^{3} / \mathrm{min}\right)$, $\mathrm{n}$ was larger and the following values were calculated:

$$
\begin{aligned}
\mathrm{I} & =0.470 \text { ampere } \\
\mathrm{n} & =8.5 \\
\Delta \mathrm{T}_{\mathrm{A}} & =28 \mathrm{~F}\left(\mathrm{Cell} \mathrm{B}_{5} \text { theoretical }\right) \\
\Delta \mathrm{T}_{\mathrm{A}} & =27.5 \mathrm{~F}\left(\mathrm{Cell} \mathrm{B}_{5} \text { measured }\right) \\
\mathrm{T}_{\mathrm{In}} & =133 \mathrm{~F} \\
\mathrm{~h}_{\mathrm{m}} & =0.010 \mathrm{lb} \mathrm{H}_{2} \mathrm{O} / \mathrm{lb} \mathrm{DA} .
\end{aligned}
$$

From figure 12 for the above values of $\mathrm{T}_{\mathrm{m}}$ and $\mathrm{h}_{\mathrm{m}}$, the mean steady-state electrolyte concentration in the matrix is estimated to be about $87 \% \mathrm{H}_{3} \mathrm{PO}_{4}$ and $\rho=2.3 \mathrm{ohm}-$ inches. 
Analysis of Experimental Cell 4b Performance

An analysis can now be made of Experimental Cell $4 \mathrm{~b}$ referred to earlier in this report which was representative of all single experimental cells. Using data obtained after 1123 hours of operation when the cell voltage was 2.531 volts:

$$
\begin{aligned}
\mathrm{i} & =32.8 \mathrm{amp} / \mathrm{ft}^{2} \\
\mathrm{I} & =0.910 \text { amperes } \\
\mathrm{n} & =4.0 .
\end{aligned}
$$

If the cell had been adequately insulated, the above operating conditions would have resulted in extremely high cell temperatures as shown by the following theoretical calculations (assuming all heat transferred to air stream):

$$
\begin{aligned}
\Delta \mathrm{T}_{\mathrm{A}} & =78 \mathrm{~F} \text { (theoretical) } \\
\mathrm{T}_{1} & =85 \mathrm{~F} \\
\mathrm{~T}_{2} & =163 \mathrm{~F} \text { (theoretical) } \\
\mathrm{T}_{\mathrm{m}} & =222 \mathrm{~F} \text { (theoretical) } .
\end{aligned}
$$

Actually, only about 4 percent of the heat generated in the cell was transferred to the air stream based on the approximate measured value of $\Delta \mathrm{T}_{\mathrm{A}}=3 \mathrm{~F}$. Using the latter value the following estimates were made:

$$
\begin{aligned}
\mathrm{T}_{1} & =85 \mathrm{~F} \\
\mathrm{~T}_{2} & =88 \mathrm{~F} \\
\Delta \mathrm{T}_{\mathrm{A}} & =3 \mathrm{~F} \\
\mathrm{~T}_{\mathrm{m}} & =90 \mathrm{~F} \\
\mathrm{~h}_{1} & =0.0131 \mathrm{~b} \mathrm{H} \mathrm{H}_{2} \mathrm{O} / \mathrm{lb} \mathrm{DA} \\
\mathrm{h}_{2} & =0.00981 \mathrm{~b} \mathrm{H} \mathrm{H}_{2} \mathrm{O} / 1 \mathrm{~b} \mathrm{DA} \\
\mathrm{h}_{\mathrm{m}} & =0.0065 \mathrm{lb} \mathrm{H}_{2} \mathrm{O} / \mathrm{lb} \mathrm{DA} .
\end{aligned}
$$

From figure 12 , it is seen that the above combination of $T_{m}$ and $h_{m}$ cor responds to a mean steady-state electrolyte concentration of $77 \% \mathrm{H}_{3} \mathrm{PO}_{4}$ with 
$\rho \cong 2.8 \mathrm{ohm}$-inches. From the latter value of specific resistance the calculated value of "c" checks well with the constant in the characteristic voltage equation for Cell $4 \mathrm{~b}$ representing a steady-state condition at $32.8 \mathrm{amp} / \mathrm{ft}^{2}$ :

$$
\begin{aligned}
& c=0.0033(2.8)=0.0092 \text { volts } / \mathrm{amp} / \mathrm{ft}^{2} \\
& E=2.020+0.140 \log i+0.0092 i .
\end{aligned}
$$

\section{Choice of Operating Conditions}

The estimates made with the use of theoretical equations appear to be consistent with the observed performance of the vapor cells. Wide variations in steady-state electrolyte concentration are possible by varying the inlet humidity, inlet temperature, air flow rate, and current density. It is also evident that once a cell matrix has been initially impregnated with a definite amount of acid, there are only certain combinations of operating conditions permissible to avoid "flooding" or loss of electrolyte as spray. With the use of the generalized equations and figure 12, the expected steadystate electrolyte concentration can be predicted and the initial acid impregnation made accordingly. Since all of the information necessary for this preferred approach was not available at the time the experimental cells and laboratory model were constructed and impregnated with acid, the evidence of acid loss from the cells was not interpreted as a basic problem of vapor cells. With regard to acid spray loss, the experimental results thus far are considered inclusive and there is indirect evidence that acid loss can be made negligible for an optimization of design and operation.

From the analysis of cell operation that has been presented, it is apparent that the performance of a vapor cell cannot be specified with regard to inlet air properties alone. The important criteria of vapor cell operation are the temperature and concentration of acid in the matrix under steady-state conditions which together determine the items of original importance in this study:

(1) Voltage characteristics (i.e., temperature and acid concentration are the principal determinants of the constants "a", " $\mathrm{b}$ ", and "c" in the cell-voltage equation for a specific matrix design).

(2) Reliability as evidenced by extended operation with stable voltage characteristics is influenced by the temperature and acid concentration (i.e., stability of matrix and platinizedplatinum electrodes). 
With regard to stability of materials, temperature would be expected to be the more important factor; difference in acid concentration probably has little effect on materials over the range of 70-95 percent $\mathrm{H}_{3} \mathrm{PO}_{4}$ of interest for vapor cells operated on cabin air. Since the majority of experimental evidence on extended operational capability for 1000 hours or more was obtained at relative low temperature $\left(T_{m} \cong 90 \mathrm{~F}\right)$, it is important to show why the test conditions for the experimental cells were representative of expected vapor-cell operation. While the laboratory model performed adequately for the initial 300-hour test, the experimental conditions imposed created a rather severe test of materials with regard to temperature $\left(T_{m}=135-145 \mathrm{~F}\right)$. In order to define normal operating conditions for a vapor cell, it is necessary to digress and consider how a vapor cell will be integrated into a cabin air system.

Integration for Cabin Air Conditioning

Usually, the amount of water contributed to the cabin air by a man (both respiration and perspiration) exceeds slightly the amount of water required for production of breathing oxygen. For simplicity as sume that a man consumes $21 \mathrm{~b} \mathrm{O} /$ day and gives up the equivalent water $\left(2.251 \mathrm{~b} \mathrm{H}_{2} \mathrm{O} /\right.$ day) to the cabin atmosphere. Thus, under steady-state conditions, the watex consumed by electrolysis in the vapor cell equals the water added to the air in the cabin.

When the vapor cell is also a dehumidifier, the main concern is the humidity control; tempcrature control can be considered independently. If the cabin air is used to cool electronic equipment, suitable heat exchangers can be provided ahead of the electrolysis cell to provide any inlet air temperature desired above the dewpoint. Likewise, it is assumed that heat exchangers can be used to cool the air leaving the electrolysis cell to any temperature (above the dewpoint) desired for the air returned to the cabin. (Also, heat exchangers could be used between in-line electrolysis units as suggested in figure 13, shown later, if this were desirable.)

Considering only the absolute humidity, it is obvious that for the system proposed whereby all of the cabin air passes through the electrolysis cell, that $h_{2}$ (cell outlet humidity) equals the cabin inlet humidity and $h_{1}$ (the cell inlet humidity) equals the cabin outlet humidity. Therefore, the water output of a man in the cabin can be defined in terms of a humidity ( $h_{\mathrm{e}}^{\prime}$ ) with reference to the air flow through the cabin analogous to the humidity supplied for electrolysis:

$$
h_{e}^{\prime}=\frac{h_{1}}{n}=h_{e} .
$$


The average humidity in the cabin and the average humidity of air passing through the electrolysis cell is

$$
\begin{aligned}
& h_{a v}=\frac{h_{1}+h_{2}}{2} \\
& h_{a v}=h_{1}\left(1-\frac{1}{2 n}\right) .
\end{aligned}
$$

Assume that the average temperature in the cabin is $75 \mathrm{~F}$, with an inlet temperature of $65 \mathrm{~F}$ and an outlet temperature of $85 \mathrm{~F}$. [The units of humidity (h) are $\left.1 \mathrm{~b} \mathrm{H}_{2} \mathrm{O} / \mathrm{lb} \mathrm{DA}\right]$. If $\mathrm{h}_{1}=0.013$ and $\mathrm{n}=2, \mathrm{~h}_{2}=0.0065$ and $\mathrm{h}_{\mathrm{av}}=$ 0.00975 (about $50 \% \mathrm{RH}$ at $75 \mathrm{~F}$ ). The latter value of average humidity falls within the comfort zone at $75 \mathrm{~F}$. However, it is not too practical to operate the electrolysis cell at $n=2$. Higher values of $n$ are required to achieve reasonable electrolysis-cell temperature. The values used for evaluation of the laboratory model of $n=6.7$ (at $21.5 \mathrm{amp} / \mathrm{ft}^{2}$ ) and $\mathrm{n}=8.5$ (at $16.9 \mathrm{amp} /$ $\mathrm{ft}^{2}$ ) correspond to air flow rates of 11.2 and $14.3 \mathrm{ft}^{3} / \mathrm{min}$ per $\mathrm{man}$ at $\mathrm{h}_{1}=$ 0.013 . The latter values are in the range of the air flow rates in pressuresuit loops. However, as the air flow rate is increased with $h_{1}=0.013$, the average humidity ( $\left.h_{a v}\right)$ maintained in the cabin increases to $0.012(n=6.7)$ and $0.0123(n=8.5)$. The latter values of humidity are outside the comfort zone for a cabin temperature of $75 \mathrm{~F}$. Therefore, the value of $\mathrm{h}_{1}$ would have to be reduced to a value in the range of 0.005 to 0.010 to maintain a comfortable humidity at higher air recirculation rates.

A consideration of the small blower power required for air flow through the electrolysis cell suggests that a much higher air flow could be used with very little added power and would be desirable to reduce the temperature at which the electrolysis cell operates. As the air flow increases there is less change in humidity of air passing through the electrolysis unit and less change in humidity of air passing through the cabin. Therefore, the value of $h_{1}$ will be close to $h_{a v}$ and should be a comfortable humidity. For example, a value of $\mathrm{h}_{1}=0.0075$ and $\mathrm{n}=20$ would maintain an average cabin humidity of $h_{a v}=0.0073$ which at $75 \mathrm{~F}$ corresponds to about $40 \% \mathrm{RH}$ and is an ideal comfort combination even at relative low cabin air velocity.

As will be shown in the following example, a preferred cabin air humidity and a higher value of $n=20$ will produce a combination of electrolyte concentration and low temperature in the vapor-cell matrix that will be about the same value as that at which the experimental cells were evaluated in extended runs of over 1000 hours. Thus, there is little doubt that the vapor cell will perform satisfactorily with the lower inlet humidity. This can be verified in a future evaluation of a new laboratory model unit designed 
and operated in accordance with the following example of preferred conditions.

\section{Preferred Operating Conditions for Vapor Cell}

With the knowledge now available to predict the performance of a vapor cell, it is possible to preselect operating conditions that will be most favorable to extended cell performance and reliability while maintaining the air within the cabin at a desirable humidity. From the preferred operating conditions, the steady-state electrolyte concentration and temperature can be estimated and a knowledgeable choice of initial electrolyte impregnation can be made at the time the cells are constructed.

Assume that the cabin air is to be maintained at approximately $75 \mathrm{~F}$ and 40 percent relative humidity. The outlet cabin air is passed through a heat exchanger which provides an inlet air to the vapor cell of $75 \mathrm{~F}$ and an inlet humidity of

$$
\begin{aligned}
\mathrm{h}_{1} & =\frac{0.01882(40)}{100}=0.00751 \mathrm{~b} \mathrm{H} \mathrm{H}_{2} \mathrm{O} / \mathrm{lb} \mathrm{DA} \\
\mathrm{v} & =\frac{19.15(75+460)}{760}[1+1.608(0.0075)]=13.69 \mathrm{ft}^{3} / 1 \mathrm{~b} \\
\mathrm{C}_{\mathrm{p}} & =0.24+0.45(0.0075)=0.243 \\
\Delta \mathrm{T}_{\mathrm{A}} & =\frac{4620(0.0075)(\mathrm{E}-1.25)}{\mathrm{n}}=\frac{142.5(\mathrm{E}-1.25)}{\mathrm{n}} .
\end{aligned}
$$

Since the design will provide for a relatively low matrix temperature as was obtained with the experimental cells, the voltage characteristics of Cell $4 \mathrm{~b}$ after 1123 hours of operation (table 7) will be assumed and a design current density of $20 \mathrm{amp} / \mathrm{ft}^{2}$ :

$$
\begin{aligned}
E & =2.020+0.140 \log (20)+0.0092(20) \\
E & =2.39 \text { volts } \\
\Delta T_{A} & =\frac{142.5(2.39-1.25)}{n}=\frac{162.5}{n} \\
T_{m} & =75+1.75\left[\frac{162.5}{n}\right] .
\end{aligned}
$$


In order to have low vapor-cell temperatures, a value of $n=20$ will be assumed and the following values calculated:

$$
\begin{aligned}
& \mathrm{n}=20 \\
& \mathrm{~T}_{1}=75 \mathrm{~F} \\
& \mathrm{~T}_{2}=75+\frac{162.5}{20}=83 \mathrm{~F} \\
& T_{m}=75+1.75\left(\frac{162.5}{20}\right)=89 \mathrm{~F} \\
& \mathrm{~h}_{1}=0.0075 \mathrm{lb} \mathrm{H} \mathrm{H}_{2} \mathrm{O} / 1 \mathrm{~b} \mathrm{DA} \\
& h_{2}=0.0075-\frac{0.0075}{20}=0.00711 \mathrm{~b} \mathrm{H} \mathrm{H}_{2} \mathrm{O} / 1 \mathrm{~b} \mathrm{DA} \\
& \mathrm{h}_{\mathrm{av}}=\frac{0.0075+0.0071}{2}=0.0073 \mathrm{lb} \mathrm{H} 2 \mathrm{O} / 1 \mathrm{~b} \mathrm{DA} \\
& \text { (39\% RH at } 75 \mathrm{~F} \text { in cabin) } \\
& \mathrm{h}_{\mathrm{m}}=0.0075\left(1-\frac{2}{20}\right)=0.00675 \mathrm{lb} \mathrm{H} \mathrm{H}^{\mathrm{O} / \mathrm{lb} \mathrm{DA} .}
\end{aligned}
$$

From figure 12 the above values of $\mathrm{T}_{\mathrm{m}}$ and $\mathrm{h}_{\mathrm{m}}$ indicate an average steadystate electrolyte concentration of $76 \% \mathrm{H}_{3} \mathrm{PO}_{4}$ which at $89 \mathrm{~F}$ has a specific resistance of $\rho=2.8 \mathrm{ohm}$-inches. Thus

$$
c=(0.0033)(2.8)=0.0092 \mathrm{ohm}-\mathrm{ft}^{2} \text {, }
$$

as assumed for the voltage equation.

The initial acid impregnation of the matrix can be designed for the expected steady-state electrolyte concentration of $76 \% \mathrm{H}_{3} \mathrm{PO}_{4}$ using equations derived in Appendix B. The void fraction (f) or available porosity of the matrix is not known accurately but could be determined. An approximate value of ( $f$ ) can be determined by a visual observation of the amount of acid required to just fill the voids. Experience with the matrix used in this study indicates a value of $f=0.50$. The volume factor $(x)$ can be obtained from figure B-1 in Appendix B or calculated from the specific gravity of 1.58 for $76 \% \mathrm{H}_{3} \mathrm{PO}_{4}$ as shown below:

$$
\begin{aligned}
x_{76} & =\frac{8.43}{(76)(1.58)}=0.070 \text { in. }{ }^{3} \text { electrolyte } / \text { gram } P_{2} O_{5} \\
e & =\frac{f}{x}=\frac{0.50}{0.070}=7.1 \mathrm{~g} \mathrm{P}_{2} \mathrm{O}_{5} / \mathrm{in.}^{3} \text { matrix volume. }
\end{aligned}
$$


The acid can be added as $85 \% \mathrm{H}_{3} \mathrm{PO}_{4}$ (readily available) to the total matrix volume of 0.22 in. ${ }^{3}$ ( 2.05 by 2.05 by 0.053 inch).

$$
\text { (7. 1) } \begin{aligned}
(0.22) & =1.56 \mathrm{~g} \mathrm{P}_{2} \mathrm{O}_{5} \text { per cell } \\
\frac{1.56}{0.615} & =2.5 \mathrm{~g} \text { of } 85 \text { percent } \mathrm{H}_{3} \mathrm{PO}_{4} \text { per cell } \\
\frac{2.44}{1.69} & =1.5 \mathrm{~cm}^{3} \text { of } 85 \text { percent } \mathrm{H}_{3} \mathrm{PO}_{4} \text { per cell }
\end{aligned}
$$

The above volume of acid is only $3 / 4$ of the acid used for the present laboratory model.

A particular advantage of the use of high value of $\mathrm{n}$ is that the steadystate electrolyte concentration of $76 \% \mathrm{H}_{3} \mathrm{PO}_{4}$ is close to the equilibrium concentration of electrolyte corresponding to the inlet air temperature and humidity (i.e., $67 \% \mathrm{H}_{3} \mathrm{PO}_{4}$ for $\mathrm{T}_{1}=75 \mathrm{~F}$ and $\mathrm{h}_{1}=0.0075 \mathrm{lb} \mathrm{H}_{2} \mathrm{O} / \mathrm{lb} \mathrm{DA}$ as can be seen in figure 12). Thus, if the electrolysis power to the vapor cell were interrupted and the air flow through the cell continued, there would be less chance of flooding for dilution to $67 \% \mathrm{H}_{3} \mathrm{PO}_{4}$ as discussed in Appendix B:

$$
\begin{aligned}
\mathrm{x}_{67} & =\frac{8.43}{(67)(1.49)}=0.084 \text { in. }{ }^{3} / \mathrm{g} \mathrm{P}_{2} \mathrm{O}_{5} \\
t_{x} & =[(7.1)(0.084)-0.50](0.053) \frac{4.2}{4.0}=0.0019 \mathrm{inch} .
\end{aligned}
$$

Thus, the increase in electrolyte thickness in excess of the matrix thickness $\left(t_{x}\right)$ could be easily accommodated by the 0.003 -inch-wire electrode screens on either side of the matrix.

Other values calculated with the equations indicated from Appendix $C$ for $\mathrm{n}=20$ and $\mathrm{i}=20 \mathrm{amp} / \mathrm{ft}^{2}$ are

$$
\begin{aligned}
\mathrm{I} & =0.555 \text { amperes per cell } \\
\mathrm{q}^{\prime} & =0.25 \mathrm{ft}^{3} / \mathrm{min} \text { per cell } \\
\mathrm{q}_{\mathrm{T}} & =57 \mathrm{ft}^{3} / \mathrm{min} \text { per man } \\
\mathrm{V} & =11.5 \mathrm{ft} / \mathrm{sec} \\
\mathrm{N}_{\mathrm{Re}} & =310
\end{aligned}
$$




$$
\begin{aligned}
\Delta P & =0.013 \text { psi } \\
P_{f} & =0.021 \text { watt per cell (blower power) } \\
\left(P_{f}\right)_{\text {total }} & =4.8 \text { watts per man (blower power). }
\end{aligned}
$$

The estimated blower power of $4.8 \mathrm{watts} / \mathrm{man}$ (based only on the pressure drop through the electrolysis cell and assuming a 50 percent blower efficiency) is only 1.5 percent of the electrolysis power of $304 \mathrm{watt} / \mathrm{man}$. The weight penalty for the blower power is $1.45 \mathrm{lb} / \mathrm{man}$ (for $P_{p}=0.3 \mathrm{lb}$ / watt) compared to the cell weight of about $7.5 \mathrm{lb} / \mathrm{man}$. The added penalty for blower power because of the use of a high air flow rate $(n=20)$ is equivalent to an electrolysis cell voltage of only 0.038 volt which is small compared to the voltage reduction obtained by platinizing the electrodes. Longer life (>1000 hours) of the platinizing is expected for the lower cell temperatures (i.e., $\mathrm{T}_{\mathrm{m}}=89 \mathrm{~F}$ ) that will exist with the higher air flow. The preferred operating conditions provide an electrolyte temperature and concentration very close to the values estimated to have existed during extended operation of experimental cells.

A heat exchanger would be needed to cool the air to $75 \mathrm{~F}$ or less after it leaves the electrolysis cell and before return to the cabin. The total amount of heat added to the air by electrolysis is dependent on the cell voltage but is independent of the volumetric rate of air flow. Thus, for the assumed cell voltage of 2.39 volts:

$$
\text { Excess heat }=(2.39-1.25)(127)=145 \mathrm{watts} / \mathrm{man} .
$$

The weight penalty for disposal of excess heat is about 1/10 the weight penalty for electrolysis power and thus is usually not a large factor in optimizing electrolysis cells. However, the small effect of the weight penalty for heat rejection and blower power is discussed later in connection with engineering estimates and choice of optimum design current density. 


\section{CELL DESIGN CONCEPTS AND ENGINEERING ESTIMATES}

\section{Cell Design for Operation on Cabin Air}

\section{Weight Reduction}

A significant result of the present work is the finding that the cell weight can be reduced appreciably from estimates based on prior research (i. e., for a 3-man cell about 150 pounds based on prior Battelle studies for the Air Force and about 110 pounds based on prior studies for NASA). Table 9 shows a detailed comparison of cell component weights to indicate where the weight has been eliminated, mainly in cell case and gas channels.

Some of the important improvements in cell design leading to weight reduction are

(1) Reduction of the size of the air passage by a realistic appraisal of fluid dynamics (i.e., pressure drop) with respect to air flow for mass transfer and heat transfer.

(2) Elimination of oversized gas channels at the cathode. While an air channel is required for the relatively large air flow in a single cell ( 1000 to $8000 \mathrm{~cm}^{3} / \mathrm{min}$ ), very little passageway is required for the hydrogen (less than $\left.10 \mathrm{~cm}^{3} / \mathrm{min}\right)$. Thus, microporous Teflon proved to be adequate.

(3) Reduction in electrode weight by use of 80-mesh, 3-mil wire instead of 45-mesh, 7.8-mil wire (a 25-30 percent reduction relative to the final cell weight).

(4) Reduction in ineffective matrix area and edge-sealing area not essential to electrochemical performance.

Normally emphasis on weight reduction is not of primary concern during research investigations and is deferred to later development. However, for the vapor cell which has an inherently high operating cell voltage, it was important to emphasize the unique cell design advantages that are reflected in low cell weight. The low cell weight combined with reduction in cell voltage with platinized-platinum electrodes that can be maintained over 1000 hours are the features that now make the vapor cell look attractive at the present state of the art. 
TABLE 9. COMPARISON OF EXPERIMENTAL-CELL WEIGHT SHOWING PROGRESS IN DESIGN

\begin{tabular}{|c|c|c|c|c|}
\hline & \multicolumn{4}{|c|}{ Component Weight, grams } \\
\hline & Cell I (a) & Cell 3 & Cell 4b & $\begin{array}{c}\text { Lab Model } \\
\text { Cell(b) }\end{array}$ \\
\hline Anode & 6.52 & 8.78 & 1.50 & 1.5 \\
\hline Cathode & 6.52 & 8.70 & 1.50 & 1.5 \\
\hline Matrix & 3.25 & -- & - & -- \\
\hline Asbestos (Cathode) & -- & 0.47 & 0.39 & 0.4 \\
\hline Asbestos (Anode) & - - & 0.48 & 0.37 & 0.4 \\
\hline Microporous Rubber & -- & 1.38 & 1. 06 & 1.1 \\
\hline Air Baffle & 16.85 & 11.26 & 7.04 & 3.6 \\
\hline $\mathrm{H}_{2}$ Baffle & 21.30 & 11.56 & -- & -- \\
\hline Microporous Teflon (10-Mil) & - & -- & 0.33 & 0.4 \\
\hline Microporous Teflon (28-Mil) & - - & -- & 2.03 & Not needed \\
\hline Lead Wires & (c) & (c) & 1.00 & 0.2 \\
\hline Cell Case & $57.4^{(d)}$ & $\ldots$ & -- & -- \\
\hline Top Cover & -- & 2. 14 & -- & -- \\
\hline Bottom Cover & -- & 1.91 & 2.50 & 0.6 \\
\hline Gaskets & 1.95 & 0.57 & -- & -- \\
\hline Silicone Sealer & -- & 1.0 & 0.61 & 1.7 \\
\hline Total Dry Weight & 98.0 & 48.2 & 18.3 & 11.4 \\
\hline Electrolyte & 5.2 & 4.4 & 3.5 & 3.4 \\
\hline Total Weight ( 4 In. ${ }^{2}$ ), g & 119.0 & 52.6 & 21.8 & 14.8 \\
\hline Specific Weight $\left(\mathrm{S}_{\mathrm{w}}\right), \mathrm{lb} / \mathrm{ft}^{2}$ & 9.4 & 4. 2 & 1. 7 & 1.2 \\
\hline
\end{tabular}

(a) Cell weights for 16 -in. ${ }^{2}$ cell were divided by 4 for comparison.

(b) An average cell derived from the weight for the laboratory model. Components added later solely for the experimental evaluation are not included. The estimated weight of silicone sealer used was obtained by difference from the lab model weight and the high value reflects the excess sealer used.

(c) Included in electrode weight.

(d) Derived from reported estimate of $110 \mathrm{lb}$ for 3 -man cell. 
Another reason for emphasis on weight reduction was to guide the research work so that the experimental data would be obtained at representative current densities. The electrochemical performance and reliability of most water-electrolysis systems is better at lower current densities and the vapor cell would be no exception. The choice of representative current densities for research study must be guided by realistic estimates of power penalty and cell weight. Estimates of total system weight are more reliable when they are direct extrapolations of power consumption and cell weight obtained from demonstration models operated at representative conditions.

\section{New Cell Design Concept}

Part of the cell weight reduction has been obtained by a new design concept which capitalizes on the unique application of a vapor cell in a cabin air-recirculation system. Other water-electrolysis systems depend on a supply of liquid water and the cell effluent is pure oxygen which is collected and transported to some point for direct use or storage. Thus, the need for piping and cell construction to convey oxygen. However, the vapor cell is unique in that pure oxygen is not collected as such but rather continuously replenishes the air stream recirculated to the cabin. Thus, there is no real need for oxygen ducts, air inlet, or air outlet ducts other than the normal air recirculating ducts.

Proposed Prototype Design

Figure 13a is a schematic of the laboratory model unit constructed on this project which was a battery of ten cells in series. The proposed construction of the hydrogen channel and two metal straps also serving as battery voltage leads might be of advantage when batteries are assembled into a prototype unit as suggested by the schematic of figure $13 \mathrm{~b}$.

In designing for operation at 28 volts, there are only a few specific combinations of series cells and cell voltage of interest:

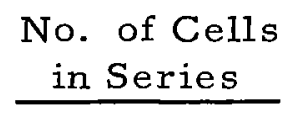

10

11

12

13

14

\begin{tabular}{c}
$\begin{array}{c}\text { Voltage/Cell, } \\
\text { volts }\end{array}$ \\
\hline 2.80 \\
2.54 \\
2.33 \\
2.15 \\
2.00
\end{tabular}




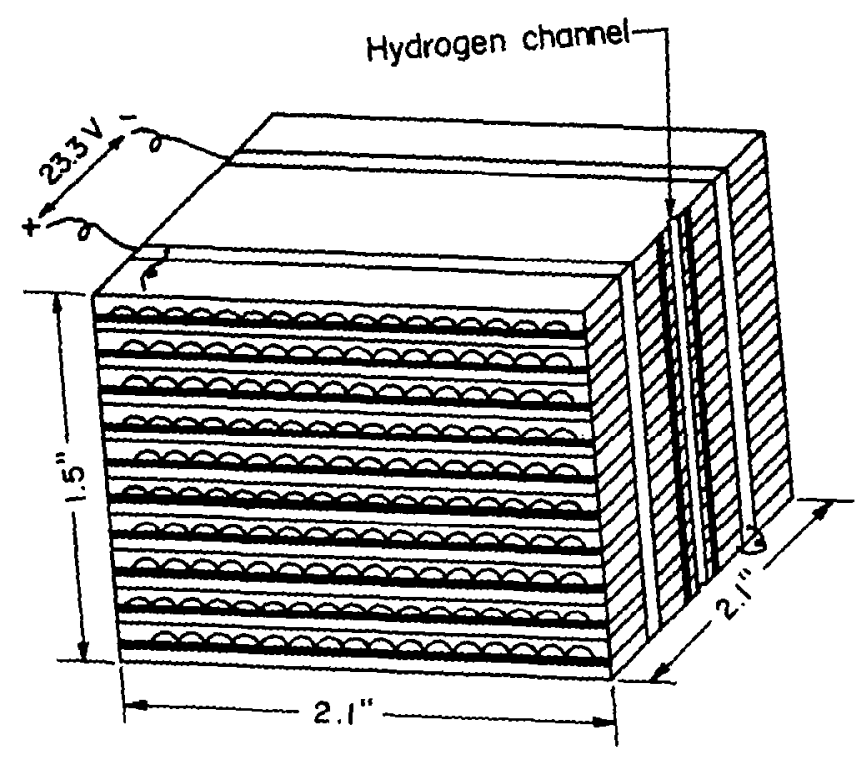

a. Laboratory Model (Battery of Cells Connected in Series Electrically)

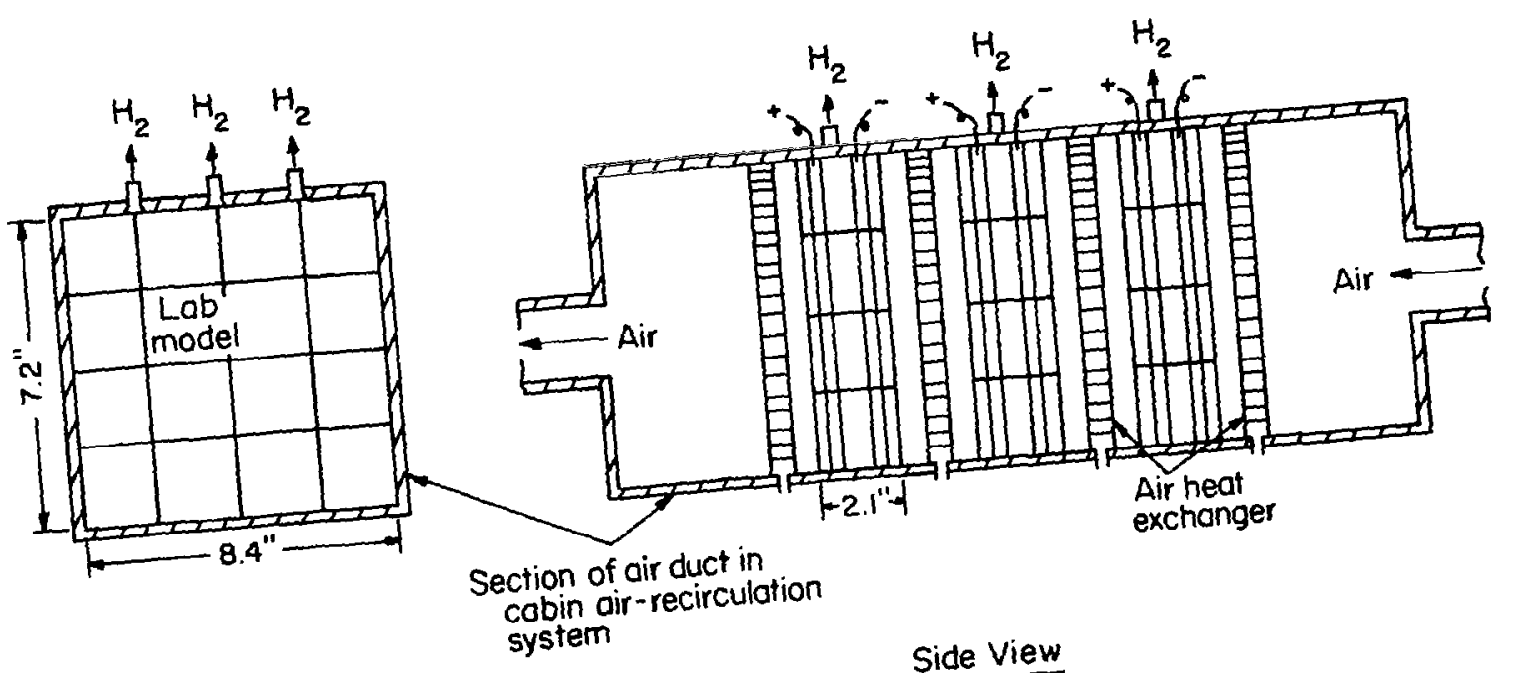

Front View

b. 3-Man Prototype Unit FIGURE 13. SCHEMATIC OF A PROPOSED ARRANGEMENT OF
LABORATORY MODEL UNITS IN 3-MAN PROTOTYPE UNIT 
For a particular set of nominal operating conditions which define the average voltage characteristics, there is only one design current density. The electrolysis area per cell can be adjusted as necessary to arrive at a convenient combination of series cells and batteries. For example, using the voltage characteristics of figure 11, a convenient choice for 28-volt operation is a battery size of 12 cells in series at 2.33 volt/cell which requires a design current density of about $24 \mathrm{amp} / \mathrm{ft}^{2}$. Using the experimental cell size with 4 -in. ${ }^{2}$ electrode area, a one-man prototype can be made from 16 batteries:

$$
\begin{gathered}
16 \text { batteries x } 12 \text { cells / battery x }\left(\frac{4}{144}\right) \mathrm{ft}^{2} / \text { cell } \\
\text { x } 24 \mathrm{amp} / \mathrm{ft}^{2}=127 \text { amperes } .
\end{gathered}
$$

The above amperage corresponds to $2 \mathrm{lb} \mathrm{O} /$ day; the one-man prototype would use about 10.6 amperes at 28 volts.

The "front view" of figure 13b shows how the 16 batteries could be arranged in the air duct of the cabin air-recirculation system. The cross section required is about 60 in. 2 and the depth of the prototype in the air flow direction would be 2.1 inches (for a 1 -man prototype). Air flow and pressure drop through each cell would be identical. Larger prototypes could be constructed in a similar manner with proportionate increase in cross section of the air-duct section housing the water-vapor-electrolysis cells.

An alternative arrangement for larger prototypes (2- to 6-man or larger) is the in-line arrangement shown in the "side view" of figure 13b illustrating a 3-man prototype. Whether the batteries are all in one plane or "in-line" does not influence the product of total air flow and pressure drop (i. e., blower power); similar considerations apply to a single 3-man prototype with a length of air flow path of 6.3 inches per cell. However, the arrangement of three separate 1-man prototypes "in-line" as shown in figure $13 \mathrm{~b}$ has the advantage of allowing intermediate air cooling with heat exchangers so that each battery can operate at the same temperature. The inlet air humidity to each successive unit would be less at low relative air flow (n value) which might be an advantage if a large decrease in humidity through the total unit is desired. The decrease in inlet humidity for successive units could be made insignificant at high relative air flow ( $\cong 20$ ).

The general design concept of the vapor cell for use in a cabin airrecirculation system appears to be versatile enough to satisfy a wide range of air-conditioning requirements and overall dimensional configurations. The use of a small cell size and a large number of batteries would appear to 
favor operational reliability. If provision is made for bypassing defective batteries, the remaining batteries could easily carry the higher currentdensity load because of the low design current density.

An important aspect of the design concept is the use of a basic cell unit (each cell identical with respect to construction, aerodynamics, and electrochemical conditions of operation) so that no scale-up problems are anticipated. Since the basic unit was evaluated in the experimental program, estimates based on extrapolating the basic cell unit performance to varioussize prototypes appear to be valid.

\section{Engineering Estimates for a Vapor Cell}

Size, Weight, and Electrolysis Power

At the beginning of this project, it was believed that estimates regarding cell size and weight might normally be less as the design basis increased from a 1-man prototype to a 6-man prototype. This might still be true for use of a larger basic cell size than $4 \mathrm{in.}{ }^{2}$. However it no longer appears to be a very significant factor for engineering estimates since in the final cell design evolved for the vapor cell, cell casing and the like are only a small percentage of the total cell weight and volume.

Therefore, estimates of cell size, weight, and electrolysis power consumption for any size prototype are simple multiples of the estimates for a 1-man prototype shown in figure 14. Figure 14 was derived by extrapolation of the actual size, weight, and power consumption of an average cell in the 10-cell laboratory model battery. The following values were used as a basis for figure 14:

$\begin{array}{ll}\text { Weight of Laboratory Model } & 0.32 \text { pound } \\ \text { Dimensions of Laboratory Model } & 2.1 \times 2.1 \\ \times 1.5 \text { inches . }\end{array}$

The following values were calculated using as a basis the electrolysis area $\left(f t^{2}\right):$

$\begin{array}{ll}\text { Specific weight }\left(\mathrm{S}_{\mathrm{w}}\right) & 1.2 \mathrm{lb} / \mathrm{ft}^{2} \\ \text { Specific volume }\left(\mathrm{S}_{\mathrm{v}}\right) & 0.014 \mathrm{ft}^{3} / \mathrm{ft}^{2} .\end{array}$




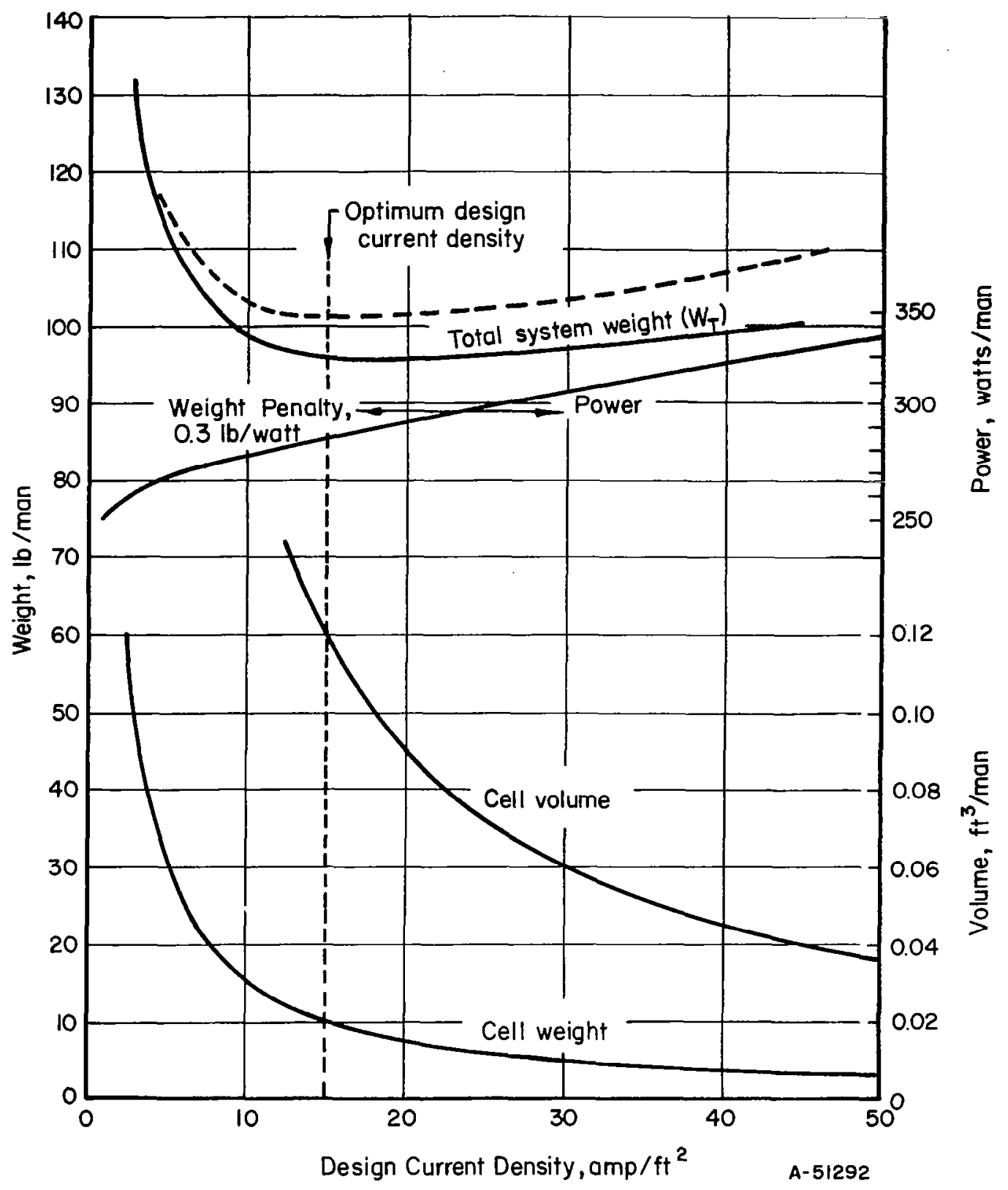

FIGURE 14. DESIGN ESTIMATES FOR A WATER-VAPORELECTROLYSIS UNIT (PHOSPHORIC ACID ELECTROLYTE)

Estimates derived from operation of a laboratory model unit. Dashed line for "total system weight" includes an estimated penalty for blower power and heat rejection under preferred operating conditions. 
For a 1 -man prototype ( $2 \mathrm{lb} \mathrm{O}_{2} /$ day) the equivalent current is 127 amperes and

$$
\begin{aligned}
& \text { Prototype weight }=\frac{(1.2)(127)}{i}=\frac{15}{i} 1 \mathrm{bs} / \mathrm{man} \\
& \text { Prototype volume }=\frac{(0.014)(127)}{i}=\frac{1.8}{i} \mathrm{ft}^{3} / \mathrm{man} .
\end{aligned}
$$

The typical voltage characteristics for an average cell based on performance of the laboratory model (figure 11) are

$$
\begin{aligned}
& E=a+b \log i+c i \\
& E=1.97+0.15 \log i+0.0072 i \\
& \text { Power consumed }=127 \mathrm{E} \text { watts } / \mathrm{man} .
\end{aligned}
$$

Assuming a power penalty of $300 \mathrm{lb} / \mathrm{kw}$ :

$$
\begin{aligned}
\text { Weight penalty for power } & =38 \mathrm{E} \mathrm{lb} / \mathrm{man} \\
\text { Total system weight } & =38 \mathrm{E}+\frac{15}{i} \mathrm{lb} / \mathrm{man} .
\end{aligned}
$$

\section{Optimum Current Density}

A general equation for total system weight $\left(W_{T}\right)$ (exclusive of blower power and heat penalty) for any number of men (M) based on $2 \mathrm{lb} \mathrm{O}_{2} /$ manday is:

$$
\mathrm{w}_{\mathrm{T}}=127 \mathrm{M}\left[\mathrm{P}_{\mathrm{p}}(\mathrm{a}+\mathrm{b} \log \mathrm{i}+\mathrm{ci})+\frac{\mathrm{S}_{\mathrm{w}}}{\mathrm{i}}\right] \text {. }
$$

The optimum current density, $i^{*}$, corresponding to minimum total system weight, can be found by differentiating the above equation with respect to current density and setting the result equal to zero and solving for current density:

$$
i^{*}=\frac{b}{2 c}\left[\sqrt{1+\frac{4 c S_{w}}{P_{p} b^{2}}}-1\right] .
$$

The optimum current density of $i^{*}=15 \mathrm{amp} / \mathrm{ft}^{2}$ shown in figure 14 was calculated from the above equation using the following values: 


$$
\begin{aligned}
\mathrm{b} & =0.15 \\
\mathrm{c} & =0.0072 \\
\mathrm{~S}_{\mathrm{w}} & =1.2 \mathrm{lb} / \mathrm{ft}^{2} \\
\mathrm{P}_{\mathrm{p}} & =0.3 \mathrm{lb} / \mathrm{watt} .
\end{aligned}
$$

At the optimum design current density, the following estimates are made for the system:

$$
\begin{array}{ll}
\text { Cell weight } & 10 \mathrm{lb} / \mathrm{man} \\
\text { Cell volume } & 0.12 \mathrm{ft}^{3} / \mathrm{man} \\
\text { Voltage } & 2.25 \mathrm{volt} / \mathrm{cell} \\
\text { Power } & 285 \mathrm{watt} / \mathrm{man} \\
\text { Power penalty } & 86 \mathrm{lb} / \mathrm{man} \\
\text { Total system weight } & 96 \mathrm{lb} / \mathrm{man}
\end{array}
$$

While the above values are optimum for a power penalty of $0.3 \mathrm{lb} /$ watt, a lower power penalty would increase the optimum current density (i.e., $25 \mathrm{amp} / \mathrm{ft}^{2}$ for $0.15 \mathrm{lb} / \mathrm{watt}$ ). As shown in figure 14 , there is relatively little difference in total system weight $( \pm 5 \mathrm{lb} / \mathrm{man})$ over a design currentdensity range of about 6 to $60 \mathrm{amp} / \mathrm{ft}^{2}$. The lower current densities might be favored for lower cell voltage and power demand; the higher current densities might be favored to reduce electrode cost.

Blower Power and Heat Rejection

For simplicity, the current-density optimization has considered only the electrolysis power. Actually the weight penalty for blower power and weight penalty for dissipation of excess electrolysis heat should be considered. Usually, the latter are small enough to be neglected in comparison to electrolysis power but for the new design of the vapor cell they became large in comparison to cell weight at high current density. The weight penalty for blower power $\left(w_{. b}\right)$ is 


$$
\begin{aligned}
\left(P_{f}\right)_{\text {total }} & =0.0328\left(\frac{\mathrm{v} \nu}{\mathrm{h}^{2}}\right)\left(\frac{\mathrm{L}^{2}}{\mathrm{~b}^{13}}\right)\left(\frac{\mathrm{n}^{2}}{\eta}\right) i \\
\mathrm{~W}_{\mathrm{b}} & =\mathrm{P}_{\mathrm{p}}\left(\mathrm{P}_{\mathrm{f}}\right)_{\text {total }} .
\end{aligned}
$$

For the preferred operating conditions of $\mathrm{h}_{1}=0.0075 \mathrm{lb} \mathrm{H}_{2} \mathrm{O} / \mathrm{lb} \mathrm{DA}$ and $n=20$, the weight penalty as a function of design current density for $P_{p}=0.3 \mathrm{lb} /$ watt is

$$
\begin{aligned}
\left(P_{f}\right)_{\text {total }} & =0.24 \mathrm{i} \text { watt } / \text { man } \\
W_{b} & =0.07 \mathrm{i} \mathrm{lb} / \mathrm{man} .
\end{aligned}
$$

The heat in watts contributed by the electrolysis unit that must be disposed of is the electrolysis power $\left(P_{e}\right)$ minus the heat of reaction:

$$
\text { Excess heat }=P_{e}-158 \mathrm{watt} / \mathrm{man}
$$

The electrolysis power (watts/man) increases with current density as shown in figure 14 and assuming a heat-rejection penalty of $0.03 \mathrm{lb} /$ watt for heat available above $70 \mathrm{~F}$, the weight penalty for heat $\left(W_{h}\right)$ is:

$$
\mathrm{W}_{\mathrm{h}}=0.03 \mathrm{P}_{\mathrm{e}}-4.7 \mathrm{lb} / \mathrm{man} .
$$

At the optimum design current density of $15 \mathrm{amp} / \mathrm{ft}^{2}$, the values are $\mathrm{W}_{\mathrm{b}}=1.1 \mathrm{lb} / \mathrm{man}$ and $\mathrm{W}_{\mathrm{h}}=3.8 \mathrm{lb} / \mathrm{man}$; at $50 \mathrm{amp} / \mathrm{ft}^{2}$ the values are $\mathrm{W}_{\mathrm{b}}=$ $3.5 \mathrm{lb} / \mathrm{man}$ and $\mathrm{W}_{\mathrm{h}}=5.1 \mathrm{lb} / \mathrm{man}$. If the total system weight shown is modified as shown by the dashed line in figure 14 to include the above weight penalties $\left(W_{b}+W_{h}\right)$, the effect is to accentuate that the minimum system weight occurs at the optimum design current density of $15 \mathrm{amp} / \mathrm{ft}^{2}$ for the assumptions used.

\section{Electrode Cost}

Electrode cost has not been a criterion in evaluation of the vapor cell on this project. However, the cost of platinum electrodes is a factor of interest in discussion of water-vapor-clectrolysis cells relative to other water-electrolysis systems.

Based on an approximate cost of $\$ 3 /$ in. 2 for woven platinum screen electrodes (80-mesh, 3-mil wire), the total clectrode cost as a function of design current density is 


$$
\text { Cost }=\frac{110,000}{i} \text { dollars } / \text { man. }
$$

For example, at the optimum design current density of $15 \mathrm{amp} / \mathrm{ft}^{2}$ the cost of platinum would be $\$ 7300$ for a 1 -man prototype. A large initial investment in platinum would be required for evaluation of large prototype units but much of the cost of platinum electrodes can be recovered at least as metal value.

The above cost equation can be used with figure 14 in considering reduction in electrode cost for operation at higher design current density than the optimum for minimum system weight. From about $15 \mathrm{amp} / \mathrm{ft}^{2}$ to $50 \mathrm{amp} / \mathrm{ft}^{2}$, about $\$ 750 / \mathrm{man}$ of decreased electrode cost can be achieved for each pound of increased system weight for comparison with the cost of placing a pound in orbit.

The cost of $\$ 3 /$ in. $^{2}$ for platinum screen is less than half the cost of platinum electrodes used in prior studies of the vapor cell and resulted from the primary effort to reduce electrode and cell weight. Platinum appears to be the best electrode material for long-term reliability, particularly for the anode. Less expensive electrode material than platinum screen might be developed in the future if such research and extended testing as needed to prove electrode reliability is warranted (i.e., the 1000 to 10,000 -hour periods of operation are of ultimate interest for oxygen-recovery systems).

\section{Comparative Estimates}

As can be seen in table 10 , the estimate for the $\mathrm{P}_{2} \mathrm{O}_{5}$ vapor cell compares favorably with other systems. Significant reduction in weight of the rotating cell has been made, but there are no extended operational data available at the present time to support claims of reliability or estimated cell voltage. Further research is needed on the $\mathrm{Pd}-\mathrm{Ag}$ cell $(\sim 25 \mathrm{lb}$ for 3 -man cell) and at the present state of the art only 24 hours' operation has been demonstrated at 2.0 volts in a laboratory experiment (ref. 9)

The ion-exchange membrane cell (ref. 8) is probably at the most advanced state of development but no specific data on operational reliability are available.

The indications of at least 1000 hours of stable voltage operation on this project begin to make the $\mathrm{P}_{2} \mathrm{O}_{5}$ vapor cell look very attractive. A relatively high power penalty was used in the comparison of table 10 . Obviously, 
any future reduction in power penalty will favor the higher voltage $\mathrm{P}_{2} \mathrm{O}_{5}$ vapor cell and provide a lower comparative total weight.

TABLE 10. COMPARISON OF SEVERAL ELECTROLYSIS METHODS

Based on estimated cell voltage and weights for an assumed power penalty of $300 \mathrm{lb} / \mathrm{kw}$ (3-man unit, 381 amperes, $6 \mathrm{lb} \mathrm{O}$ /day).

\begin{tabular}{|c|c|c|c|c|}
\hline Method & $\begin{array}{c}\mathrm{P}_{2} \mathrm{O}_{5} \\
\text { Vapor Cell }\end{array}$ & $\begin{array}{l}\text { Rotating } \\
\text { Cell(a) }\end{array}$ & $\begin{array}{l}\text { Ion-Exchange } \\
\text { Membrane(b) }\end{array}$ & $\begin{array}{c}\text { Pd-Ag Static } \\
\text { Cell(c) }\end{array}$ \\
\hline Cell Voltage, volts & 2.25 & 1.87 & 1.87 & $1.6-2.0$ \\
\hline $\begin{array}{l}\text { Design Current } \\
\text { Density, } \operatorname{amp} / \mathrm{ft}^{2}\end{array}$ & 15 & 37 & About 40 & 75 \\
\hline $\begin{array}{l}\text { Power Weight } \\
\text { Penalty, 1b }\end{array}$ & 258 & 214 & 214 & $183-229$ \\
\hline Cell Weight, lb & 30 & 120 & 135 & 25 \\
\hline Total Weight, $1 \mathrm{~b}$ & 288 & 334 & 349 & $208-253$ \\
\hline Total Volume, $\mathrm{ft}^{3}$ & $\sim 0.4$ & $\sim 3.6$ & $\sim 5.2$ & $\sim 0.2$ \\
\hline
\end{tabular}

(a) Recent estimates for new rotating cell designed and built at Battelle (Contract AF 33(615)-1495).

(b) Based on reported values of $180 \mathrm{lb}$ and 945 watts for 4-man flight prototype (ref. 8).

(c) Ref. 9.

\section{CONC LUSIONS}

The principal cause of the relatively high cell voltage for a water vapor electrolysis cell with a phosphoric acid electrolyte is concentration polarization, mainly at the anode. The concentration polarization was shown to be typical of the high acid concentrations required for operation of the cell at typical cabin air humidities. The current-interruption technique of voltage analysis was successfully applied to identification of the components of cell polarization. The use of platinized-platinum electrodes greatly reduced the activation polarization and extended operational tests showed that the improvement in cell voltage can be maintained for at least 1000 hours. 
Operational performance of experimental vapor cells was consistent with the theoretical analysis of operation with respect to fluid dynamics, heat transfer, mass transfer, and electrochemistry. Extended operation with stable voltage characteristics was indicated for cells designed and operated under specified conditions within the normal range of cabin air temperature and humidity. Specifically the initial acid impregnation of the matrix must be consistent with the steady-state electrolyte concentration expected in order to minimize flooding and loss of electrolyte entrained in the air stream.

Improvements in cell design and reduction in cell weight have made the vapor cell look attractive in comparison with other water electrolysis systems at the present state of the art.

\section{RECOMMENDATIONS}

Further research and development are needed to determine the full potentialities of a water-vapor electrolysis cell with a phosphoric acid electrolyte. Research is continuing at Battelle to verify the new knowledge of cell operation obtained from theoretical analysis by further extended operational testing of experimental cells. In view of the unique integration of an electrolysis cell in a cabin air-conditioning system, further analysis is required to define the best cell operating conditions and whether under these conditions certain apparent problems are sufficiently important to warrant further research. 


\section{APPENDIX A}

\section{DISCUSSION OF CIRCUITRY FOR OBTAINING \\ POLARIZATION-DECAY CURVES}

Two methods were used to obtain oscillographic traces showing the decay of polarization with time immediately after interrupting the current. The ideal procedure is to trigger the oscilloscope trace, and then inter rupt the current when the trace is part way across the screen. This gives a base line corresponding to the closed-circuit potential, then a discontinuity occurs when the circuit is opened and the potential in the vicinity of the discontinuity can be examined carefully. The circuit designed to carry out this objective is shown in figure A-la. This is a modification of the circuit described by Trachtenberg (ref. 1). The procedure is

(1) Connect one pair of the electrodes (Ref, C, A) to the leads from the Type CA plug-in unit in the Tektronix 545 A oscillograph.

(2) Close SW 1 and adjust current at power source.

(3) Record cell voltage, current, and potential of electrode pair which was selected in Step (1) on VTVM.

(4) a. Set oscilloscope to give single beam; b. d-c input;

c. time base "A delayed by B"; d. single sweep;

e. adjust trigger level and trigger scope to give trace when SW2 is closed momentarily; f. using sweep speed of 1 millisecond per $\mathrm{cm}$, adjust sweep delay on time base " $B$ " until potential shift shows on the scope when SW2 is momentarily closed 2-3 msec; g. adjust vertical sensitivity to the smallest volts/cm which permits observation of potential break (by using for Bl, one or two 1-1/2-volt dry cells and the "position" control, the trace can be kept on screen).

(5) With the above adjustments complete, a photograph of the oscilloscope trace can be made at the moment SW2 is closed. 
The mercury relay is an essential part of this circuit because it permits currents up to $3 \mathrm{amp}$ to be interrupted with a minimum of noise. However, the time of opening of the relay after closing SW2 varies by $0.5 \mathrm{msec}$. This means that as sweep rates are decreased below $50 \mathrm{msec} / \mathrm{cm}(0.5 \mathrm{msec}$ full scale) the chance of finding the potential "break" on the screendecreases. Therefore, for studying the potential decay in detail at times in the range of a few $\mu \mathrm{sec}$ after interruption, the circuit in figure $A-1 \mathrm{~b}$ was used.

Further experience with the current-interruption technique of voltage analysis has indicated the importance of the single-sweep feature (on scopes such as the Tektronix 545A or 545B) to insure that the potential trace, immediately after triggering, is the only one displayed on the scope screen.

In the circuit in figure A-1b, a heavy current resistor was placed in series with the cell. The potential across this resistor when the cell current is on is about 3 to 5 volts so when the current is interrupted a sufficient potential change occurs to trigger the single sweep. (Note: if a differential input is used to the oscilloscope, such as on a $502 \mathrm{~A}$ or 503, one electrode of the cell must be grounded.) Follow steps in the procedure given for first circuit, omitting a., c., and f., under (4). The location of the spot on the screen must be recorded before triggering because there is no base line. With high sweep rates ( 1 to $20 \mu \mathrm{sec} / \mathrm{cm}$ ) a damped oscillation (ringing) is observed in the interval right after opening of the relay. This is an inductive effect which is difficult to avoid in interrupter techniques. The first data point was recorded from the photograph at the point where oscillations ceased. 


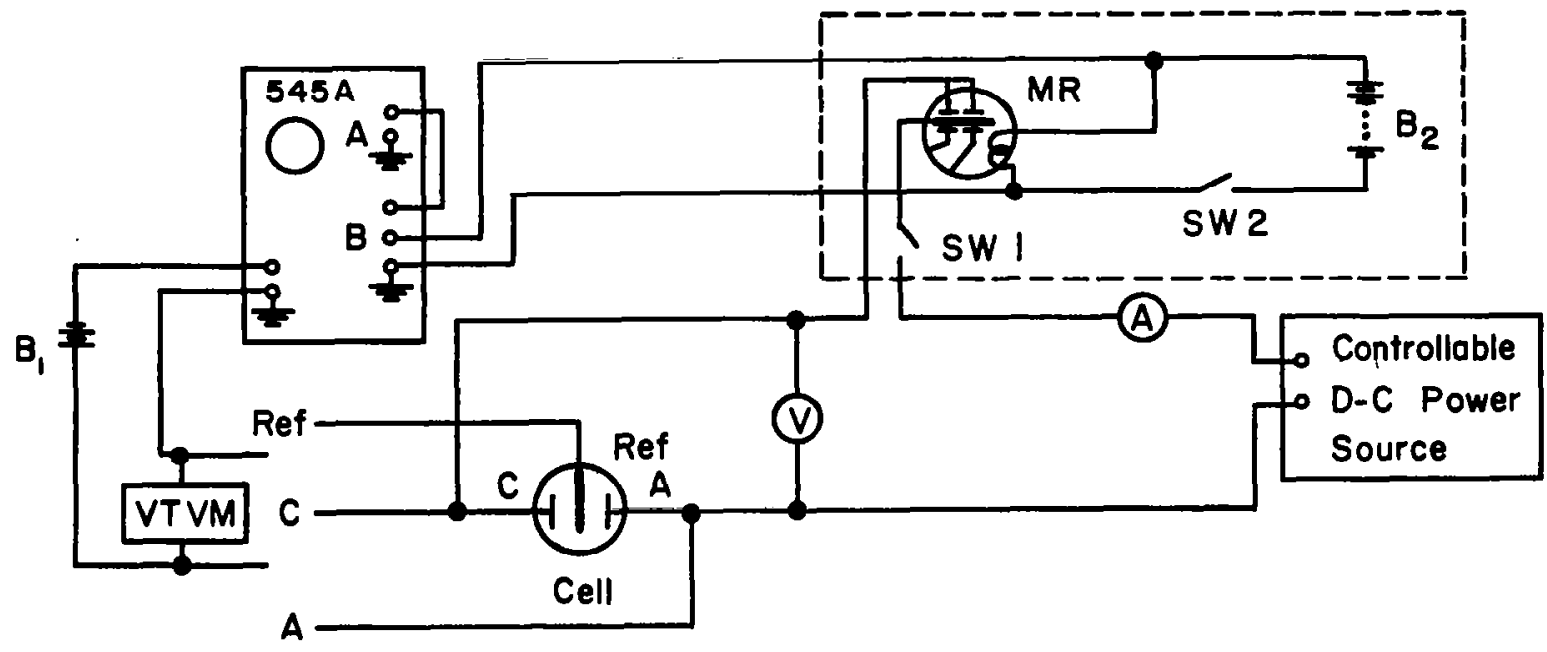

a.

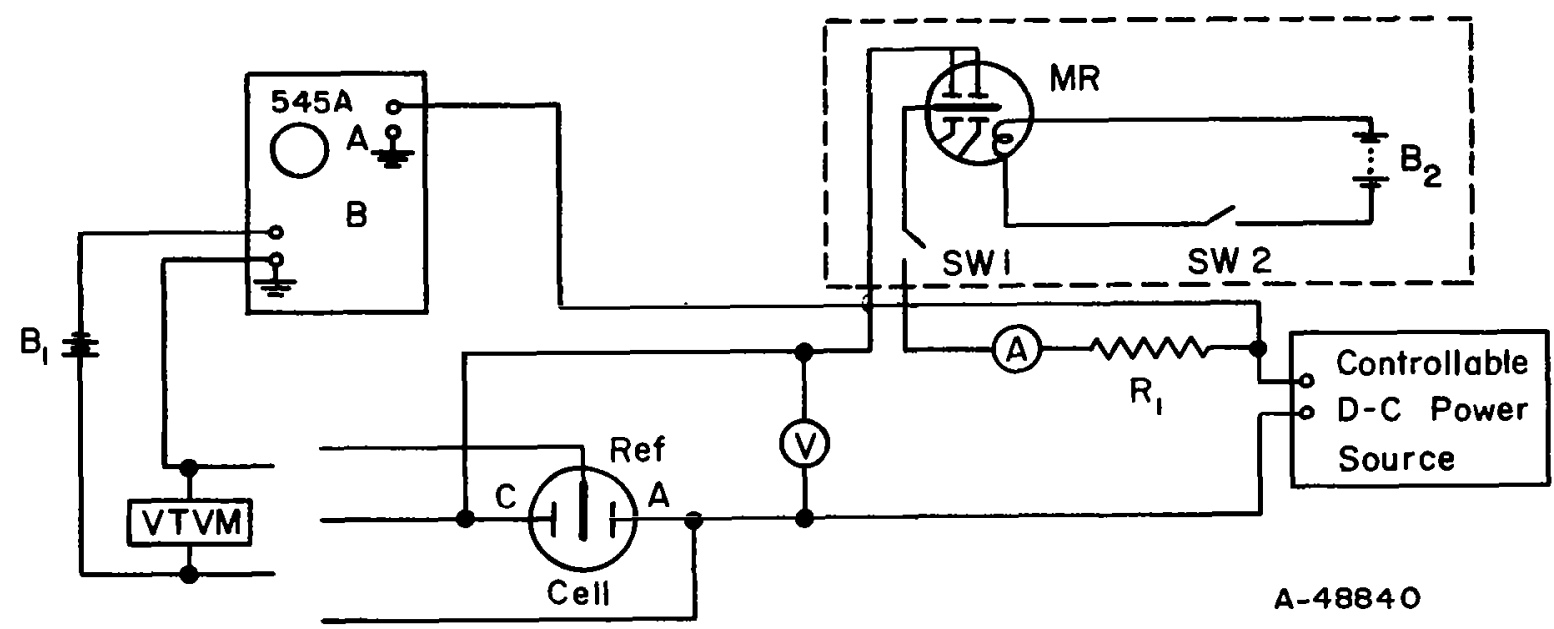

b.

FIGURE A-1. CIRCUITRY FOR OBTAINING POLARIZATIONDECAY CURVES

$\begin{array}{ll}\mathrm{B}_{1} & 0,1 \text {, or } 2,1-1 / 2 \text {-volt dry cells } \\ \mathrm{B}_{2} & 45-\text { volt dry battery } \\ \mathrm{MR} & \text { Mercury-wetted contact relay (Adams } \\ & \text { and Westlake Co., Elkhart, Ind. , } \\ & \text { Cat. no. MW-1602-1) connected in } \\ & \text { normally closed (NC) position } \\ \mathrm{R}_{1} & \text { 31-ohm, 5-amp rheostat connected as } \\ & \text { resistor }\end{array}$





\title{
APPENDIX B
}

\author{
AN ANALYSIS OF INITIAL ACID IMPREGNATION \\ AND MATRIX DESIGN IN RELATION TO \\ FLOODING OF VAPOR CELIS
}

\section{Introduction}

"Flooding" of vapor cells is a serious problem related to reliability. In this section, equations are developed which allow an estimate of the proper initial acid impregnation in relation to the matrix and expected operating conditions. This analysis was prompted by problems encountered with the earlier experimental cells and with hindsight it is possible to explain why flooding or loss of electrolyte as spray probably occurred.

\section{Derivation of Equations Relating to Initial Acid Impregnation}

The total matrix volume $\left(V_{t}\right)$ is of concern at the time of impregnation and may be larger than the effective matrix volume $\left(V_{e}\right)$ which excludes edges that are clamped or sealed:

$$
\begin{aligned}
& V_{t}=\left(L_{t}\right)\left(W_{t}\right)(t)=\left(A_{t}\right)(t) \\
& V_{e}=(L)(W)(t)=\left(A_{e}\right)(t),
\end{aligned}
$$

where $t$ is the total matrix thickness (including composite matrixes). The grams of phosphoric acid solution used for impregnation can be converted to grams of $\mathrm{P}_{2} \mathrm{O}_{5}$ added as follows for the example of 1 gram of 85 per cent $\mathrm{H}_{3} \mathrm{PO}_{4}$ :

$$
\frac{(1)(0.85)}{1.381}=0.615 \mathrm{~g} \mathrm{P}_{2} \mathrm{O}_{5} \text {. }
$$

The initial acid impregnation (e) can be specified as grams $\mathrm{P}_{2} \mathrm{O}_{5}$ per cubic inch of total matrix volume. Values of e are shown in table B-l for several experimental cells.

Figure B-1 shows the volume factor $(x)$, in. ${ }^{3}$ electrolyte/gram $\mathrm{P}_{2} \mathrm{O}_{5}$, as a function of weight percent $\mathrm{H}_{3} \mathrm{PO}_{4}$ solution* which can be calculated from the acid concentration and specific gravity (sp gr): 


$$
x=\frac{8.43}{\left(w_{t} \% \mathrm{H}_{3} \mathrm{PO}_{4}\right)(\mathrm{spgr})}
$$

If at the time of impregnation the available porosity of the matrix expressed as void fraction (f) is just filled with electrolyte then

$$
e=\frac{f}{x}
$$

If the amount of acid added initially is greater than the available pore volume, the excess will appear as a layer of acid of thickness $\left(t_{x}\right)$ distributed over the matrix area (assume half of $t_{\mathbf{x}}$ on each side of the matrix). For assembled cells the excess acid is free to expand only over the effective matrix area $\left(A_{e}\right)$. The following equation can be used to calculate $t_{x}$ in inches for initial impregnation or after dilution to some lower acid concentration during operation by use of the appropriate value of $x$ from figure $B-1$ :

$$
t_{x}=(e x-f) t \frac{A_{t}}{A_{e}}
$$

For the case where the volume of acid is insufficient to completely fill the available porosity (i. e., $t_{x}$ is minus) the fraction of the available pores filled with electrolyte $\left(t_{f}\right)$ is determined by the following equation:

$$
t_{f}=1-\left(\frac{f-e x}{f}\right)
$$

Flooding

Flooding of vapor cells can occur when abnormal conditions are encountered that result in dilution of the electrolyte in the matrix to a lower concentration with an increase in volume that cannot be retained by the matrix. Probably some of the excess thickness of electrolyte $\left(t_{x}\right)$ can be retained by the fine-mesh screen electrodes. As an approximation, the amount of excess electrolyte $\left(t_{x}\right)$ that can be retained is assumed to be $2 \mathrm{w}$ where $w=$ wire size of screen electrode in inches. The thickness of the woven screen electrodes is about twice the wire size but since the screens are about 50 percent open area, the equivalent thickness available for electrolyte is about $w$ for each electrode. Assuming that any electrolyte thickness beyond $2 \mathrm{w}$ would be permanently lost from the cell (i. e., flooding), the following equations indicate the limiting condition:

*Figure B-1 was derived from density data for phosphoric acid solutions at $35 \mathrm{C}$ (ref. 5). 
TABLE B-1. COMPARATIVE SUMMARY OF INITIAL ACID IMPREGNATION OF EXPERIMENTAL VAPOR CELLS

\begin{tabular}{|c|c|c|c|c|c|}
\hline Cell: & (a) & No. 1 & No. 2 & No. 3 & No. $4 \mathrm{~b}$ \\
\hline Screen Electrode Wire Size (w), inch & 0.0078 & 0.0078 & 0.0078 & 0.0078 & 0.003 \\
\hline Matrix Thickness ( $t$ ), inch & 0.043 & 0.036 & 0.020 & 0.053 & 0.053 \\
\hline Total Matrix Area $\left(A_{t}\right)$, in. 2 & 27 & 27 & 2.1 & 5.1 & 4.2 \\
\hline Total Matrix Volume $\left(V_{t}\right)$, in. ${ }^{3}$ & 1.16 & 0.97 & 0.042 & 0.27 & 0.22 \\
\hline Effective Matrix Area $\left(A_{\mathrm{e}}\right)$, in. 2 & 16 & 16 & 1.1 & 4.0 & 4.0 \\
\hline Initial $\mathrm{P}_{2} \mathrm{O}_{5}$ Addition, $\mathrm{g}$ & 28.6 & 14.9 & 0.83 & 2.7 & 2.1 \\
\hline $\begin{array}{l}\text { Initial Impregnation (e). g } \mathrm{P}_{2} \mathrm{O}_{5} / \text { in }_{*}{ }^{3} \\
\text { of total matrix volume }\end{array}$ & 24.7 & 15.3 & 19.8 & 10.0 & 9.5 \\
\hline
\end{tabular}

(a) Prior NASA studies, Run 96, table 1, 8th Monthly Report.

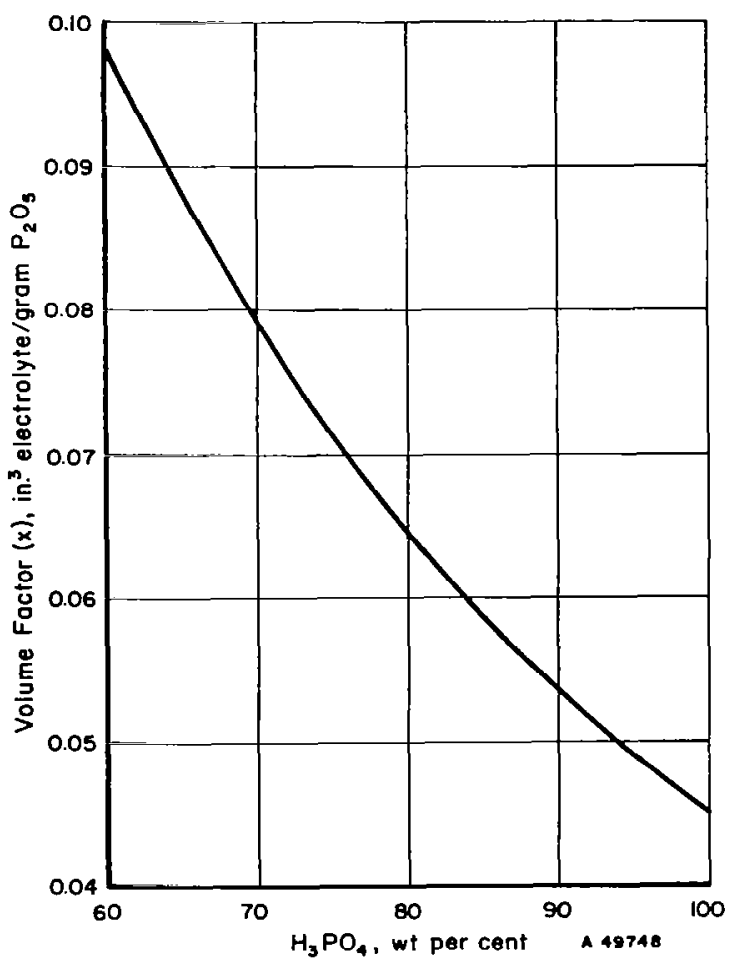

FIGURE B-1. VOLUME FACTOR OF PHOSPHORIC ACID AS A FUNCTION OF CONCENTRATION 


$$
\begin{aligned}
t_{x} & =(e x-f) t \frac{A_{t}}{A_{e}}-2 w=0 \\
e & =\left(\frac{2(w)\left(A_{e}\right)}{(t)\left(A_{t}\right)}+f\right) \frac{1}{x}
\end{aligned}
$$

The optimum acid impregnation e for partial protection against flooding can be determined from (B9) by using a value of $x$ from figure $B-1$ corresponding to a concentration of $\mathrm{H}_{3} \mathrm{PO}_{4}$ that might exist under abnormal conditions.

\section{$\underline{\text { Acid Spray }}$}

Compared to "flooding", loss of electrolyte by acid spray (aerosol of electrolyte formed by exploding oxygen bubbles) requires a more accurate definition of the steady-state electrolyte concentration in the matrix. At present, the optimum value of $t_{x}$ to minimize acid spray while maintaining good voltage characteristics can only be estimated from empirical observations. For example, if observations show that acid spray is minimized for operation at a particular steady-state concentration of electrolyte, a value of $x^{\prime}$ can be determined from (B4) or figure B-l and assuming reasonable values of $(f)$ and $(t)$ an optimum value of $t_{x^{\prime}}$ calculated

$$
t_{x^{\prime}}=\left(e x^{\prime}-f\right) t \frac{A_{t}}{A_{e}}
$$

Using the value of $t_{x}$, from (Bl0), the optimum initial acid impregnation can be estimated for any other steady-state condition ( $\left.x^{\prime}\right)$

$$
e=\left(\frac{t_{x^{\prime}} A_{t}}{t A_{e}}+f\right) \frac{1}{x^{\prime}}
$$

If the values of (f) and ( $t$ ) assumed for (B10) are also used in (BII), the value of e calculated by the empirical approach should be a good estimate. Obviously, precise measured values of ( $f$ ) and $(t)$ would be preferred for calculation of the initial acid impregnation. In practice, the porosity (f) and thickness $(t)$ of matrix materials vary within production quality-control limits. Also the degree of compression of the matrix during cell assembly will influence both (f) and (t).

The above analysis and equations are only approximate but are useful for preliminary estimates. The interrelation of initial acid impregnation and the ability of the matrix to prevent cross leak of gases under various steadystate and transient operating conditions could be a subject of detailed study. 
Suggested Matrix Design Improvements for Resistance to Flooding

The following tentative conclusions regarding matrix design and initial acid impregnation for resistance to flooding have resulted from analysis of the above equations:

(1) The ratio of $A_{t} / A_{e}$ should be as small as possible (Cell $4 \mathrm{~b}$ had a low ratio) to reduce the relative change in $t_{x}$ for increase in $x$.

(2) The matrix thickness should be as thin as practical.

(3) The matrix porosity should be as low as practical.

Since a thin matrix is also desirable for reduction of ohmic polarization to achieve lower cell voltage, the only limitation in this direction is providing sufficient resistance to cross leak of gases. The indication that the matrix porosity should be reduced is important since a reduction in porosity could provide the needed resistance to gas cross leak as the matrix is made thinner. There appears to be room for improvement of the present combination matrix of 0.053 -inch thickness since the differential gas pressure across the matrix is relatively low for normal operating conditions (about $1 / 2$ the air flow pressure drop, which is low based on calculations in Appendix C). 


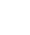




\section{APPENDIX C}

\section{DERIVATION OF THEORETICAI EQUATIONS \\ DESCRIBING VAPOR-CELL OPERATION}

\section{Fluid Dynamics}

Material Balance

A water balance for a vapor cell under steady-state conditions shows that

$$
h_{1}-h_{2}=h_{e}-h_{h},
$$

where

$$
\begin{aligned}
& \mathrm{h}_{1}=\text { inlet air humidity, } 1 \mathrm{~b} \mathrm{H}_{2} \mathrm{O} / 1 \mathrm{~b} \mathrm{DA} \\
& \mathrm{h}_{2}=\text { outlet air humidity, } 1 \mathrm{~b} \mathrm{H}_{2} \mathrm{O} / \mathrm{lb} \mathrm{DA} \\
& \mathrm{h}_{\mathrm{e}}=\text { water consumed by electrolysis, } 1 \mathrm{~b} \mathrm{H}_{2} \mathrm{O} / \mathrm{lb} \mathrm{DA} \\
& \mathrm{h}_{\mathrm{h}}=\text { water leaving cell with hydrogen, } 1 \mathrm{~b} \mathrm{H}_{2} \mathrm{O} / 1 \mathrm{~b} \mathrm{DA}
\end{aligned}
$$

The use of "l pound of dry air" (lb DA) as a basis allows definitions in terms of "absolute humidities" ( $\mathrm{lb}_{2} \mathrm{O} / \mathrm{lb} \mathrm{DA}$ ) which greatly simplifies the understanding of vapor-cell operation in terms of mass transfer of water vapor. As will be shown later, the amount of water $\left(h_{h}\right)$ that is removed from the air stream, absorbed in the electrolyte at the anode, transported across the matrix to the cathode, evaporated from the electrolyte at the cathode, and leaves the cell with the hydrogen gas is small compared to the water consumed in electrolysis $\left(\mathrm{h}_{\mathrm{e}}\right)$. Therefore, as a first approximation, for steady-state operation of a vapor cell, the water removed from the air in passing through the cell practically equals the water consumed by electrolysis:

$$
\mathrm{h}_{1}-\mathrm{h}_{2}=\mathrm{h}_{\mathrm{e}} \quad \text {. }
$$


An important design parameter is the relative air flow factor ( $n$ ) defined as the ratio of the actual amount of water supplied by the inlet air $\left(h_{1}\right)$ to the theoretical amount of water required for electrolysis ( $h_{e}$ )

$$
\mathrm{n}=\frac{\mathrm{h}_{1}}{\mathrm{~h}_{\mathrm{e}}}
$$

The relative air flow factor $(n)$ can also be defined as the ratio of the actual rate of water supplied by the inlet air $\left(\dot{w}_{1}\right)$ to the rate of water consumption by electrolysis ( $\left.\dot{w}_{e}\right)$ :

$$
\mathrm{n}=\frac{\dot{\mathrm{w}}_{1}}{\dot{\mathrm{w}}_{\mathrm{e}}}
$$

The water consumed by electrolysis according to Faraday's law is:

$$
\frac{18}{(2)(96,500)(454)}=2.05 \times 10^{-7} 1 \mathrm{~b} \mathrm{H} 2 \mathrm{O} / \mathrm{amp}-\mathrm{sec}
$$

The theoretical rate of water supply $\left(w_{e}\right)$ for any current (I) is:

$$
\dot{\mathrm{w}}_{\mathrm{e}}=2.05 \times 10^{-7} \text { (I) }
$$

The rate of water supplied to the cell in the inlet air is:

$$
\dot{\mathrm{w}}_{1}=\frac{(\mathrm{q})\left(\mathrm{h}_{1}\right)}{(60)(\mathrm{v})}
$$

The relative air flow rate ( $n$ ) can be obtained by substituting equations (C6) and (C7) in (C4):

$$
\begin{gathered}
n=\frac{(q)\left(h_{1}\right)}{(60)(v)\left(2.05 \times 10^{-7}\right) I} \\
n=\frac{81,300\left(h_{1}\right)(q)}{(v)(I)}
\end{gathered}
$$

where

$$
\begin{aligned}
& \mathrm{q}=\text { volumetric air flow rate, } \mathrm{ft}^{3} / \mathrm{min} \\
& \mathrm{v}=\text { specific volume of moist inlet air, } \mathrm{ft}^{3} / \mathrm{lb} \mathrm{DA}
\end{aligned}
$$


The specific volume of the moist air can be determined from psychometric tables and charts or calculated from the following equation for the inlet air temperature $\left(T_{1}\right)$ and humidity $\left(h_{1}\right)$ :

$$
v=\frac{19.15\left(\mathrm{~T}_{1}+460\right)}{P}\left[1+16.08\left(\mathrm{~h}_{1}\right)\right] \text {. }
$$

Equation $(\mathrm{C} 10)$ is useful if the total air pressure (P) is other than atmospheric.

The humidity of the outlet air $\left(h_{2}\right)$ can be determined easily by the use of the parameter (n) when equations (C2) and (C3) are rearranged and combined:

$$
\begin{aligned}
& h_{e}=\frac{h_{1}}{n} \\
& h_{2}=h_{1}-h_{e} \\
& h_{2}=h_{1}\left(1-\frac{1}{n}\right)
\end{aligned}
$$

From equation (C9) it can be seen that if the inlet air properties ( $\mathrm{h}_{1}$ ) and $(v)$ do not change, the parameter $(n)$ is proportional to the ratio of air flow rate to current (q/I). Thus ( $n$ ) characterizes any size electrolysis unit if the values of air flow rate and current apply to that size unit. Several variations of equation (C9) can be used such as the use of primes to denote a single experimental cell:

$$
\mathrm{n}=\frac{81,300\left(\mathrm{~h}_{1}\right)\left(\mathrm{q}^{\prime}\right)}{(\mathrm{v})\left(\mathrm{I}^{\prime}\right)}
$$

For a battery of $N$ cells where $\left(q^{\prime}\right)$ and $\left(Y^{\prime}\right)$ are the airflow rate and current, respectively, of a single cell:

$$
\mathrm{n}=\frac{81,300(\mathrm{~h} 1)\left(\mathrm{q}^{\prime}\right)}{(\mathrm{v})(\mathrm{N})\left(\mathrm{I}^{\prime}\right)}
$$

For a prototype unit where $\left(q_{T}\right)$ is the total air flow rate through the electrolysis unit designed for $M$ number of men (127 amperes per man for $2 \mathrm{lbO}_{2} /$ man-day)

$$
\mathrm{n}=\frac{8 \mathrm{I}, 300\left(\mathrm{~h}_{1}\right)\left(\mathrm{q}_{\mathrm{T}}\right)}{(127)(\mathrm{v})(\mathrm{M})}
$$


The total volumetric air flow rate $\left(\mathrm{q}_{\mathrm{T}}\right)$ is often of interest and can be obtained for a specified value of $(n)$ :

$$
\mathrm{q}_{T}=\frac{(127)(\mathrm{v})(\mathrm{M})(\mathrm{n})}{(81,300) \mathrm{h}_{1}}
$$

For generalized design equations the current density ( $i$ ) is more descriptive than the absolute current. Any basic experimental cell size can be used (rather than the 2 by 2 -inch size of this study) if the electrolysis area is defined in terms of length $(L)$ in the air flow direction and width $(W)$ perpendicular to $L$ and parallel to the electrode:

$$
I=\frac{(i)(L)(W)}{144}
$$

Combining $(\mathrm{C} 14)$ and $(\mathrm{C} 18)$ provides a general equation for volumetric air fiow through a single cell:

$$
\begin{aligned}
& q^{\prime}=\frac{(v)\left(I^{\prime}\right)(n)}{81,300\left(h_{1}\right)} \\
& q^{\prime}=\frac{(v)(i)(L)(W)(n)}{(81,300)(144)\left(h_{1}\right)}
\end{aligned}
$$

Reynolds Number

For Reynolds number $\left(\mathrm{N}_{\mathrm{Re}}\right)$ less than about 2000 , the air flow will be laminar rather than turbulent. The Reynolds number is defined as:

$$
\mathrm{N}_{\mathrm{Re}}=\frac{\mathrm{D}_{\mathrm{e}} \mathrm{V}}{\mu \mathrm{v}} \quad \frac{\mathrm{D}_{\mathrm{e}} \mathrm{V}}{\nu}
$$

where

$$
\begin{aligned}
& \mathrm{V}=\text { mean velocity, } \mathrm{ft} / \mathrm{sec} \\
& \mathrm{v}=\text { specific volume of air, } \mathrm{ft}^{3} / \mathrm{lb} \\
& \mu=\text { viscosity, lb/ft-sec } \\
& \nu=\text { kinematic viscosity, } \mathrm{ft}^{2} / \mathrm{sec} \\
& \mathrm{D}_{e}=\text { equivalent diameter, } \mathrm{ft} .
\end{aligned}
$$

For noncircular passages, the hydraulic radius is used to calculate $D_{e}$ : 


$$
D_{e}=4 R_{H}=\frac{4 A_{d}}{L_{p}}
$$

where

$$
\begin{aligned}
& R_{H}=\text { hydraulic radius, } \mathrm{ft} \\
& \mathrm{A}_{d}=\text { cross-sectional area of duct, } \mathrm{ft}^{2} \\
& L_{\mathrm{p}}=\text { wetted perimeter, } \mathrm{ft} .
\end{aligned}
$$

For a rectangular air passage through the cell of width (W) and spacing (b),

$$
D_{e}=\frac{4(w)(b)}{2(W+b)}
$$

Where $W>b$, the equation reduces to

$$
D_{e}=\frac{2 b^{\prime}}{12(1000)}
$$

where $b^{\prime}$ is in mils and $D_{e}$ in feet.

For the experimental cells where the width is 2 inches and the spacing about 40 mils or less the above simplification of $(\mathrm{C} 2,2)$ is valid.

The air baffle used in the experimental cells had grooves ( 8 per inch) with a cross-sectional area that was a portion of a circular sector of chord $=$ 0.120 inch and height $=0.040$ inch from which was calculated the central angle $=135^{\circ}$, radius $=0.065$ inch, arc length $=0.153$ inch, and cross sectional area $=0.0035 \mathrm{in}^{2}$ :

$$
D_{e}=\frac{4(0.0035)}{(0.153+0.120)(12)} 0.0043 \mathrm{ft} \quad .
$$

This is equivalent to a rectangular section of $b^{-}=0.0043(6000)=25.8$ mils. The subsequent discussion can be greatly simplified by neglecting the grooves and considering the aerodynamically equivalent air passage as spacing $b^{\prime}$. Thus, the equivalent air passage will be assumed to be 2 inches wide with a spacing of 25.8 mils.

Substituting (C24) in (C21) provides an expression for the Reynolds number in terms of equivalent spacing $\left(b^{\prime}\right)$ :

$$
N_{R e}=\frac{(b)(V)}{6000(\nu)} \text {. }
$$


The cross-sectional area for air flow through a cell is

$$
A_{d}=\frac{(W)\left(b^{\prime}\right)}{(144)(1000)}
$$

The average air velocity (V) through the cell is

$$
V=\frac{\left(q^{\prime}\right)}{(60)\left(A_{d}\right)}
$$

Substituting $(C 20)$ and $(C 27)$ in (C28) the velocity is shown to be independent of the width of cell $(W)$ :

$$
V=\frac{(v)(i)(L)(n)}{(81.3)\left(h_{1}\right)\left(b^{\prime}\right)(60)}
$$

Substituting (C29) in (C26) provides a general expression for the Reynolds number

$$
N_{R e}=\frac{3.4 \times 10^{-8}(v)(L)(i)(n)}{\left(h_{1}\right)(\nu)}
$$

For values typical of the operation of the experimental cells: $v=14 \mathrm{ft}^{3} / 1 \mathrm{~b}$, $\mathrm{L}=2$ inches, $\mathrm{i}=32.8 \mathrm{amp} / \mathrm{ft}^{2}, \mathrm{n}=4.0, \mathrm{~h}_{1}=0.013 \mathrm{lb} \mathrm{H} \mathrm{H}_{2} \mathrm{O} / \mathrm{lb} \mathrm{DA}, \nu=$ $0.00016 \mathrm{ft}^{2} / \mathrm{sec}$ for air at $85 \mathrm{~F}$. The value calculated from $(\mathrm{C} 30)$ is $\mathrm{N}_{\mathrm{Re}}=$ 60. This value of Reynolds number indicated definite laminar flow of air through the electrolysis cell. For the practical range of variables in equation (C30), turbulent air flow is not likely or actually necessary. Note in the above equation (C30) that the value of $N_{R e}$ is independent of the width of passage (W) and the spacing (b). This is generally true for closely spaced broad parallel plates when the volumetric flow is assumed constant (according to the steady-state water demand for electrolysis). Equation (C26) shows that as the spacing $\left(b^{\prime}\right)$ is reduced, the mean air velocity increases but $\mathrm{N}_{R e}$ remains constant. There is no need to make the airpassage spacing any larger than necessary and the only limitation to small spacing is the pressure drop.

Pressure Drop

For laminar flow between broad parallel plates, the pressure drop $(\triangle P$, in psi) along the length of air path $(L)$ is defined by the following equation*:

* The theoretical equation for laminar flow between parallel plates does not have the same constant as the more familiar equation for circular ducts because of the difference in velocity distribution (i.e., relation of average velocity $V$ to maximum velocity). 


$$
\Delta P=\frac{(V)\left(\mu^{\prime}\right)(L)}{0.0478\left(\mathrm{~b}^{\prime}\right)^{2}}
$$

where

$$
\begin{aligned}
& \mu^{\prime}=\text { viscosity, centipoise } \\
& \qquad \mu^{\prime}=1488 \mu=1488 \rho \nu=\frac{1488 \nu}{\mathrm{v}} .
\end{aligned}
$$

Combining (C29), (C31), and (C32)

$$
\Delta \mathrm{P}=\frac{6.4(\nu)(\mathrm{i})(\mathrm{n})(\mathrm{L})^{2}}{\left(\mathrm{~h}_{1}\right)\left(\mathrm{b}^{\prime}\right)^{3}}
$$

Using the typical values for the experimental cells:

$$
\begin{aligned}
& \Delta P=\frac{6.4(0.00016)(32.8)(4)(2)^{2}}{(0.013)(25.8)^{3}} \\
& \Delta P=0.0024 \text { psi. }
\end{aligned}
$$

The above calculated value of pressure drop is the same as was measured during operation of experimental cells.

\section{Blower Power}

The power $\left(P_{f}\right.$ in watts $)$ required to flow air through the cell is the product of the volumetric flow rate (from equation $\mathrm{C} 20$ ) and the pressure drop (from equation $\mathrm{C} 33$ ) modified by the fractional efficiency of the fan or blower $(\eta)$ :

$$
\begin{gathered}
1 \text { horsepower }=33,000 \mathrm{ft}-1 \mathrm{~b} / \mathrm{min}=746 \text { watts } \\
P_{f}=\left[\frac{(L)(W)(i)(v)(n)}{(81,300)(144)\left(h_{1}\right)}\right]\left[\frac{(6.4)(\nu)(i)(n)(L)^{2}}{(h)\left(b^{\prime}\right)^{3}}\right] \frac{(144)(746)}{(\eta)(33,000)} \\
P_{f}=1.8 \times 10^{-6}\left(\frac{v \nu}{h_{2}}\right)\left(\frac{L^{3} W}{b^{\prime 3}}\right)\left(\frac{i^{2} n^{2}}{\eta}\right) .
\end{gathered}
$$

The total blower power per man $\left(P_{f}\right)_{\text {total }}$ can be determined by use of $(C 17)$ and $(\mathrm{C} 20)$ 


$$
\left(P_{f}\right)_{\text {total }}=\frac{\left(P_{f}\right)\left(q_{T}\right)}{q^{\prime}}=\frac{\left(P_{f}\right)(127)}{I^{\prime}} .
$$

Substituting an expression for current density in (C35a) and combining with (C35)

$$
\left(P_{f}\right)_{\text {total }}=0.033\left(\frac{\mathrm{v} \nu}{h_{1}}\right)\left(\frac{\mathrm{L}^{2}}{\mathrm{~b}^{3}}\right)\left(\frac{\mathrm{n}^{2}}{\eta}\right) i \quad
$$

The weight penalty for blower power is

$$
w_{b}=\left(P_{p}\right)\left(P_{f}\right)_{\text {total }}
$$

$\underline{\text { Heat Transfer }}$

Heat Balance

The electrical energy put into the electrolysis cell is

$$
P_{\mathrm{e}}=\mathrm{EI} \quad \text {. }
$$

The energy consumed by the chemical reaction at $77 F$ is

$$
\Delta \mathrm{H}=57,798 \mathrm{cal} / \mathrm{g}-\mathrm{mol} \mathrm{H}_{2} \mathrm{O}
$$

for the reaction: $\mathrm{H}_{2} \mathrm{O}(\mathrm{g})=\mathrm{H}_{2}(\mathrm{~g})+\mathrm{l} / 2 \mathrm{O}_{2}(\mathrm{~g})$. The excess heat put into the system that must be dissipated is

$$
Q_{\text {in }}=E I-\Delta H(f),
$$

where $\mathrm{f}$ is a conversion factor, watts $-\mathrm{g}-\mathrm{mol} \mathrm{H}_{2} \mathrm{O} / \mathrm{cal}$. From Faraday's law

$$
\begin{aligned}
& \frac{1}{(2)(96,500)}=5.18 \times 10^{-6} \mathrm{~g}-\mathrm{mol} \mathrm{H}_{2} \mathrm{O} / \mathrm{amp}-\mathrm{sec} \\
& 1 \text { calorie }=4.184 \text { watt-sec } \\
& f=\left(5.18 \times 10^{-6}\right)(4.184)(\mathrm{I})=2.17 \times 10^{-5} \mathrm{I} .
\end{aligned}
$$


Substituting (C37) and (C39) in (C38)

$$
\begin{aligned}
& Q_{\text {in }}=E I-(57,798)\left(2.17 \times 10^{-5}\right) I \\
& Q_{\text {in }}=I(E-1.25) .
\end{aligned}
$$

The above equation shows that all of the cell voltage above 1.25 volts contributes to heat that must be removed from the cell. Approximately, all of the cell voltage above the reversible cell potential of 1.23 volts (i. e., the total cell polarization) results in heat.

Temperature Rise of the Air

Assume that all of the heat generated in the electrolysis cell has to be carried away by the air stream passing through the cell. The heat removed can be determined from the air flow rate, specific heat $\left(C_{p}\right)$ and temperature rise $\left(\Delta T_{A}\right)$ of the air from inlet $\left(T_{1}\right)$ to outlet $\left(T_{2}\right)$ using the conversion factor $3.417 \mathrm{Btu} /$ watt-hr:

$$
Q_{\text {out }}=\frac{(q)(60)(C p)\left(\Delta T_{A}\right)}{(v)(3.417)} .
$$

Equating $(\mathrm{C} 40)$ to $(\mathrm{C} 41)$ and solving for $\Delta \mathrm{T}_{\mathrm{A}}$ :

$$
\Delta T_{A}=\frac{5.7 \times 10^{-2}(v)(I)(E-1.25)}{\left(C_{p}\right)(q)}
$$

Substituting the value of $\mathrm{n}$ from $(\mathrm{C} 13)$ in (C42)

$$
\Delta \mathrm{T}_{\mathrm{A}}=\frac{4620\left(\mathrm{~h}_{1}\right)(\mathrm{E}-1.25)}{\left(\mathrm{C}_{\mathrm{p}}\right)(\mathrm{n})}
$$

The specific heat for moist air of humidity $\left(h_{1}\right)$ can be calculated from the following equation

$$
\mathrm{Cp}_{\mathrm{p}}=0.24+0.45 \mathrm{~h}_{1} \quad \text {. }
$$

For the particular value of $h_{1}=0.013 \mathrm{lb} \mathrm{H}_{2} \mathrm{O} / \mathrm{lb} \mathrm{DA}$ used for the experimental study 


$$
\begin{gathered}
\mathrm{C}_{\mathrm{p}}=0.24+0.45(0.013)=0.246 \\
\Delta \mathrm{T}_{\mathrm{A}}=\frac{4620(0.013)(\mathrm{E}-1.25)}{(0.246)(\mathrm{n})} \\
\Delta \mathrm{T}_{\mathrm{A}}=\frac{244(\mathrm{E}-1.25)}{\mathrm{n}}
\end{gathered}
$$

Equation (C45) shows why well-insulated vapor cells cannot be operated at low $n$ values.

For a prototype electrolysis unit the value of $\mathrm{n}$ calculated by equation ( $\mathrm{C} 16)$ using $\mathrm{v}=14 \mathrm{ft}^{3} / \mathrm{lb}$ can be substituted in equation (C43):

$$
\begin{gathered}
\mathrm{n}=\frac{(81,300)\left(\mathrm{h}_{1}\right)\left(\mathrm{q}_{\mathrm{T}}\right)}{(127)(14)(\mathrm{M})} \\
\Delta \mathrm{T}_{\mathrm{A}}=\frac{4620(\mathrm{E}-1.25)\left(\mathrm{h}_{1}\right)(127)(14)}{(0.246)(81,300)\left(\mathrm{h}_{1}\right)\left(\mathrm{q}_{\mathrm{T} / \mathrm{M})}\right.} \\
\Delta \mathrm{T}_{\mathrm{A}}=\frac{411(\mathrm{E}-1.25)}{\left(\mathrm{q}_{\mathrm{T}} / \mathrm{M}\right)}
\end{gathered}
$$

If the total volumetric air flow rate $\left(\mathrm{q}_{\mathrm{T}}\right)$ divided by the number of men $(M)$ is

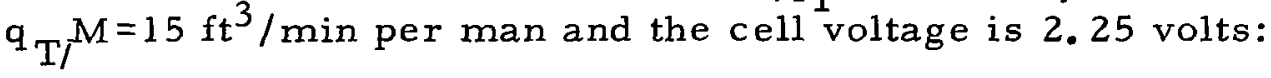

$$
\Delta \mathrm{T}_{\mathrm{A}}=\frac{411(2.25-1.25)}{15}=27.4 \mathrm{~F} \text {. }
$$

The above calculations emphasize that the temperature rise of the air stream does not depend on the electrolysis-cell design or physical dimensions. The temperature rise of the air stream does not depend on the inlet air humidity (the effect of humidity on specific heat and specific volume tend to cancel each other). The air temperature rise is directly proportional to electrolysis cell polarization and a high air flow is required to prevent high cell temperature [i.e., $15 \mathrm{ft}^{3} /$ min per man corresponds to $\mathrm{n}=9$ for $\mathrm{h}_{1}=$ $0.0131 \mathrm{~b} \mathrm{H}_{2} \mathrm{O} / 1 \mathrm{~b} \mathrm{DA}$ in equation (C46)].

For a water-vapor electrolysis cell located in an air duct for cabin air recirculation, all of the excess electrolysis energy that is converted to heat 
serves to increase the air temperature. The total temperature $r$ ise of the air stream is the same even if part of the air is diverted around the outside of the cell and only part of the air flow passes through the cell. Obviously, the most beneficial effect on maintaining a low internal cell temperature is obtained if all of the available air is passed through the cell. Similar reasoning indicates why the use of cooling fins on the electrolysis cell are of little benefit in lowering internal cell temperature if the fins are to be cooled by diverting air flow in the duct that could just as well have been passed through the electrolysis cell.

\section{Heat-Transfer Coefficient}

The heat-transfer coefficient has been determined for the analogous situation of laminar fluid flow through a wide rectangular slit. For low Reynolds numbers and small spacings ( $\left.b^{\prime}\right)$, the heat-transfer coefficient $\left(h_{a}\right)$ is given by the following equation (ref. 10):

$$
\begin{array}{r}
\frac{\mathrm{h}_{\mathrm{a}} \mathrm{D}_{\mathrm{e}}}{\mathrm{k}^{\circ}}=\mathrm{K}\left(\frac{\mathrm{D}_{\mathrm{eV}}}{\nu}\right)\left(\frac{\mathrm{C}_{\mathrm{p}} \mu}{\mathrm{k}^{\prime}}\right)\left(\frac{\mathrm{D}_{\mathrm{e}}}{\mathrm{L}}\right) \\
\mathrm{h}_{\mathrm{a}}=\mathrm{K} \frac{\mathrm{DeVC}_{\mathrm{p}}(3600)}{\mathrm{Lv}} \\
\mathrm{h}_{\mathrm{a}}=\mathrm{K} \frac{(2)\left(\mathrm{b}^{\prime}\right)(\mathrm{V})\left(\mathrm{C}_{\mathrm{p}}\right)(3600)}{\mathrm{LV}}
\end{array}
$$

where

$$
\begin{aligned}
& \mathrm{K}_{1}=1 / 2 \text { for heat transfer from both walls } \\
& \mathrm{K}_{2}=2 / 3 \mathrm{~K}_{1}=1 / 3 \text { for heat transfer from only one wall } \\
& \mathrm{h}_{\mathrm{a}}=\begin{array}{l}
\text { heat-transfer coefficient based on the average } \\
\text { temperature difference }
\end{array}
\end{aligned}
$$

$$
Q=h_{a}\left[T_{m}-\frac{T_{2}+T_{1}}{2}\right] \frac{L W}{144},
$$

where

$$
\begin{aligned}
\mathrm{T}_{\mathrm{m}}= & \text { mean temperature of electrolyte in matrix at anode } \\
& \text { screen/electrolyte interface with the air. }
\end{aligned}
$$


Assuming all of the heat generated in the electrolysis cell is transferred to the air stream flowing through the cell:

$$
\begin{aligned}
& Q=\frac{q(60)\left(C_{p}\right) \Delta T_{A}}{v} \\
& Q=\frac{b^{\prime}(V)(3600)(W)\left(C_{p}\right)\left(\Delta T_{A}\right)}{(144)(v)}
\end{aligned}
$$

Substituting (C52) in (C53), equating with (C55) and simplifying:

$$
\begin{aligned}
\Delta \mathrm{T}_{\mathrm{A}} & =2 \mathrm{~K}\left(\mathrm{~T}_{\mathrm{m}}-\frac{\mathrm{T}_{2}+\mathrm{T}_{1}}{2}\right) \\
& =2 \mathrm{~K}\left[\mathrm{~T}_{\mathrm{m}}-\left(\mathrm{T}_{1}+\frac{\Delta \mathrm{T}_{\mathrm{A}}}{2}\right)\right] \\
\mathrm{T}_{\mathrm{m}} & =\mathrm{T}_{1}+\left(1 / 2+\frac{1}{2 \mathrm{~K}}\right) \Delta \mathrm{T}_{\mathrm{A}}
\end{aligned}
$$

The value of the expression $\left(1 / 2+\frac{1}{2 K}\right)$ depends on the assumptions regarding the manner in which heat is transferred to the air stream from the walls of the air passage. For the assumption that all of the heat is transferred across one wall only (the anode screen/electrolyte interface with the air), the value of $K_{2}=1 / 3$ is used in equation (C50) and (C58) simplifies to

$$
\mathrm{T}_{\mathrm{m}}=\mathrm{T}_{1}+2.0 \Delta \mathrm{TA} \text { (one wall). }
$$

In practice, some heat will be transferred to the air stream from the wall (plastic air baffle) adjacent to the anode which will be at a higher temperature than the air. Heat will be conducted to the latter wall from the hydrogen-gas side of the adjacent cell or across the air channel at points where the air baffle touches the anode. Heat will also be transferred across the air channel by radiation from the anode surface which should be a good radiator since it is blackened. All of the above effects will tend to heat the wall of the channel opposite the anode. In the extreme case, the opposite wall could rise to the temperature of the anode and the value of $K_{2}=1 / 2$ is used in equation (C50) and (C58) simplifies to

$$
\mathrm{T}_{\mathrm{m}}=\mathrm{T}_{1}+1.5 \Delta \mathrm{T}_{\mathrm{A}} \text { (two walls). }
$$


The actual value of $T_{m}$ lies between the values calculated by (C59) and (C60). An intermediate value is used for estimates:

$$
\mathrm{T}_{\mathrm{m}}=\mathrm{T}_{1}+1.75 \Delta \mathrm{T}_{\mathrm{A}} .
$$

The value of $\mathrm{K}_{1}$ or $\mathrm{K}_{2}$ for use in (C50) is independent of air flow rate at low flow rates, that is for $\mathrm{N}_{\mathrm{Re}} \mathrm{N}_{\operatorname{Pr}}(\mathrm{De} / \mathrm{L})<8$. This corresponds, for the present system, to Reynolds numbers less than about $\mathrm{N}_{\mathrm{Re}}=450$. For $\mathrm{N}_{\mathrm{Re}}>450$, the heat-transfer coefficient does not increase in proportion to the flow rate and $T_{m}$ calculated from (C50) will be too low. Apparently, for $\mathrm{N}_{\mathrm{Re}}<450$ the exit gas is all at the same temperature. For $\mathrm{N}_{\mathrm{Re}}>450$, the temperature of the gas in the center of the channel is slightly cooler, and not quite as much heat is carried away.

Heat Removed by Hydrogen Gas

The ratio of the heat carried away by the hydrogen to the heat carried away by the air stream can be estimated from the following equation:

$$
\begin{gathered}
\frac{2 h_{1}}{18 \mathrm{n}}=1 \mathrm{~b} \mathrm{H}_{2} / 1 \mathrm{~b} \mathrm{DA} \\
\frac{\mathrm{h}_{1}\left(\mathrm{C}_{\mathrm{p}}\right)_{\mathrm{H}_{2}}}{9 \mathrm{n}\left(\mathrm{C}_{\mathrm{p}}\right)_{\mathrm{air}}}=\frac{3.5 \mathrm{~h}_{1}}{(9)(0.24) \mathrm{n}}=\frac{1.6 \mathrm{~h}_{1}}{\mathrm{n}} .
\end{gathered}
$$

For example, even if the hydrogen left at the same temperature as the air and with $h_{1}=0.0131 b \mathrm{H}_{2} \mathrm{O} / 1 \mathrm{~b} \mathrm{DA}$ and $\mathrm{n}=4$

$$
\frac{1.6(.013)}{4}=0.0052
$$

and only $1 / 2$ per cent of the heat is carried away by the hydrogen. As $n$ is increased the error is proportionally less in neglecting the heat carried away by the hydrogen.

Any water vapor leaving in the hydrogen stream has no net cooling effect on the cell. 
Heat Transfer From Anode to Cathode

Assuming the thermal conductivity of the impregnated matrix to be about $0.1 \mathrm{Btu} / \mathrm{hr}-\mathrm{ft}-\mathrm{F}$, the rate of heat transfer across the matrix from anode to cathode is

$$
\frac{\mathrm{Q}}{\mathrm{A} \triangle \mathrm{T}}=\frac{\mathrm{k}}{\mathrm{t} / 12}=\frac{(0.1)(12)}{0.053}=22.8 \mathrm{Btu} / \mathrm{hr}-\mathrm{ft}^{2}-\mathrm{F} \text {. }
$$

For a current density of $21 \mathrm{amp} / \mathrm{ft}^{2}$ and a cell voltage of 2.35 volts, the rate of heat generation in the cell is

$$
\begin{aligned}
\frac{\mathrm{Q}}{\mathrm{LW} / 144} & =(\mathrm{i})(\mathrm{E}-1.25)(3.42) \\
& =21.5(2.35-1.25)(3.42)=80 \mathrm{Btu} / \mathrm{hr}-\mathrm{ft}^{2} .
\end{aligned}
$$

Even if all the heat were transferred from the anode to cathode, the difference in temperature of the anode and cathode would be less than $4 \mathrm{~F}$. Since in practice over 90 per cent of the heat is transferred to the air stream from the anode and very little heat is transferred toward the cathode, the temperature gradient from anode to cathode is less than $0.5 \mathrm{~F}$.

Heat Transfer Parallel to Anode

While there is little temperature gradient from the anode across the matrix to the cathode there can be a temperature gradient for the electrodes and matrix from the air inlet end of the cell to the air outlet. As a first approximation one could consider that the temperature gradient for heat transfer to the air stream $\left(T_{m}-\frac{T_{1}+T_{2}}{2}\right)$ is the same value from the air inlet to the air outlet (i. e., uniform rate of heat transfer all over the anode interface). Thus

$$
T_{2}^{\prime}-T_{1}^{\prime}=\Delta T
$$

where the primes refer to the anode/electrolyte temperature and the subscripts to the air inlet and outlet. Actually, the first approximation must be modified by heat transfer along both anode and cathode and through the matrix/electrolyte in a direction parallel to the air flow but from ' ${ }^{\prime}{ }_{2}$ to $T^{\prime}{ }_{1}$. The amount of heat that can be transferred along the electrodes and matrix for temperature equalization can be compared to the heat transferred to the air. 
Assuming 80-mesh platinum wire of 3-mil diameter and including both electrodes,

$$
\begin{gathered}
A=\frac{2(0.785)(0.003)^{2}(160)}{144}=1.57 \times 10^{-5} \mathrm{ft}^{2} \\
\frac{Q}{\Delta T}=\frac{\mathrm{kA}}{\mathrm{L} / 12}=\frac{(40.6)\left(1.57 \times 10^{-5}\right)}{2 / 12}=3.82 \times 10^{-3} \frac{\mathrm{Btu}}{\mathrm{hr}-\mathrm{F}} .
\end{gathered}
$$

The value of $Q / \Delta T$ is relatively small for the matrix and can be combined with the above value:

$$
\begin{gathered}
A=\frac{(0.053)(2)}{144}=0.736 \times 10^{-3} \mathrm{ft}^{2} \\
\frac{\mathrm{Q}}{\Delta \mathrm{T}}=\frac{(0.1)\left(0.736 \times 10^{-3}\right)}{2 / 12}=0.44 \times 10^{-3} \frac{\mathrm{Btu}}{\mathrm{hr}-\mathrm{F}} \\
\frac{\mathrm{Q}^{\prime}}{\Delta \mathrm{T}}=\frac{\mathrm{Q}^{\prime}}{\mathrm{T}^{\prime} 2^{-\mathrm{T}^{\prime}}}=\frac{\mathrm{Q}^{\prime}}{\Delta \mathrm{T}_{\mathrm{A}}} \text { (approximately) } \\
\frac{\mathrm{Q}^{\prime}}{\Delta \mathrm{T}_{\mathrm{A}}}=\left(3.82 \times 10^{-3}\right)+\left(0.44 \times 10^{-3}\right)=4.3 \times 10^{-3} \frac{\mathrm{Btu}}{\mathrm{hr}-\mathrm{F}}
\end{gathered}
$$

Using a typical air flow of $q=0.053 \mathrm{ft}^{3} / \mathrm{min}$, the amount of heat transferred to the air from equation $(\mathrm{C} 41)$ is

$$
\frac{Q}{\Delta T_{A}}=\frac{60(q)\left(C_{p}\right)}{V}=\frac{(60)(0.053)(0.246)}{14}=58 \times 10^{-3} \frac{\mathrm{Btu}}{\mathrm{hr}-\mathrm{F}} \text {. }
$$

Comparing (C73) and (C74) indicates that only $\frac{4.3 \times 10^{-3}(100)}{58 \times 10^{-3}}=7$ percent of the heat can be transferred along the electrodes to equalize the electrode/ matrix temperature from inlet to outlet. The above percentage decreases as the relative rate of air flow is increased $\left(q=0.053 \mathrm{ft}^{3} / \mathrm{min}\right.$ corresponds to about $n=6.7$ for $h=0.0131 b \mathrm{H}_{2} \mathrm{O} / \mathrm{lb} \mathrm{DA}$ ).

Further knowledge of the temperature distribution in the matrix would require experimental study because of the complex interaction of heat transfer on local voltage/current density relationships. If the cell is operated at relatively high air flow rates (i. e., $n=20$ ) for relatively small $\Delta T_{A}$ the actual temperature distribution along the electrode does not appear important. 


\section{Heat Loss From Cell Case}

For a single experimental cell, the heat lost through the cell case can be a large portion of the total heat, particularly if the outer surface of the cell case is exposed to a cool air stream in turbulent flow as was the experimental cell (i.e., Cell 4b). Insulation of the cell case, particularly the 4-in. 2 area at the top and bottom of the cell, can reduce the heat loss if this is desirable for experiments.

A practical consideration of the operation of a water-vaporelectrolysis unit in a cabin air-recirculation duct indicates that practically all of the heat will be transferred to the air stream flowing through the cell. The highest temperatures will be encountered for a centrally located battery of cells and for a centrally located cell within a battery. The situation can be simulated by insulating four of the six sides of the battery or individual cell. Thus, the only external heat-transfer surfaces of the cell of practical concern are the ends facing upstream and downstream. Since the latter surfaces are also exposed to laminar air flow, they can be treated as extensions of the anode heat-transfer surface.

The same reasoning applies to any lead wires used as intercell connector which are in the air stream. For example, a value of $L=2.0$ inches has been used for the anode length. For an actual experimental cell of total length 2.1 inches plus thickness of 0.15 inch (added on at inlet and outlet), the effective length for heat transfer is 2,3 inches compared to the 2. 0 inches used in the previous derivation of equations (C59) and (C60). The maximum correction that need be applied to equation (C58) is

$$
\mathrm{T}_{\mathrm{m}}=\mathrm{T}_{1}+\left[1 / 2+\frac{1}{2(1 / 3)}\left(\frac{2.0}{2.3}\right)\right] \Delta \mathrm{T}_{\mathrm{A}}=\mathrm{T}_{1}+1.83 \Delta \mathrm{T}_{\mathrm{A}} \text {. }
$$

At most, the above correction would affect the estimate of temperature $T_{m}$ by about $5 \mathrm{~F}$ or within the limits of accuracy claimed for the approximate equation (C61).

\section{Mass Transfer}

\section{Mass-Transfer Coefficient}

In the air stream passing through the electrolysis cell water vapor diffuses toward the anode and oxygen diffuses away from the anode. According to the stoichiometry of the reaction, two molecules of water 
vapor (molecular weight $2 \times 18=36$ ) diffuse for every molecule of oxygen (molecular weight 32 ). Thus, the net flow on a weight basis is very small, and, considering the low concentration of water vapor, the diffusion velocity can probably be neglected. Being able to neglect the diffusion velocity insures that the mass-transfer equations take the same form as the heattransfer equations, and the results derived previously for heat transfer to the air stream can be applied, with only slight modifications, to the mass transfer situation.

The mass-transfer coefficient can be determined from the same equation as for heat transfer (C50) if the Prandtl number $\left(P_{r}=\frac{C_{p} \mu}{k^{\prime}}\right)$ is replaced by the Schmidt number $\left(s_{c}=\frac{\nu}{D}\right)$ and $\left(\frac{h_{a} D_{e}}{k^{\prime}}\right)$ is replaced by $\left(\frac{h_{D} D_{e}}{D}\right)$. Since mass transfer for the vapor cell will occur on only one plate of two parallel plates, the coefficient $K_{2}=1 / 3$ must be used.

$$
\begin{gathered}
\frac{\mathrm{h}_{D^{D}} \mathrm{e}}{\mathrm{D}}=\frac{1}{3}\left(\frac{\mathrm{DeV}}{\nu}\right)\left(\frac{\nu}{\mathrm{D}}\right)\left(\frac{\mathrm{De}}{\mathrm{L}}\right) \\
\frac{\mathrm{h}_{\mathrm{D}}}{\mathrm{v}}=\frac{\mathrm{D}_{\mathrm{e}} \mathrm{V}}{3 \mathrm{LV}}=\frac{2 \mathrm{~b}^{\prime} \mathrm{V}}{3 \mathrm{Lv}} .
\end{gathered}
$$

Defining $h_{D}$ analogously to $h_{a}$ in (C53):

$$
\begin{gathered}
\frac{\mathrm{w}_{\mathrm{H}_{2} \mathrm{O}}}{\mathrm{LW}}=\frac{\mathrm{hD}_{\mathrm{D}}}{\mathrm{v}}\left(\frac{\mathrm{x}_{1}+\mathrm{x}_{2}}{2}-\mathrm{x}_{\mathrm{m}}\right) \\
\frac{\mathrm{w}_{\mathrm{H}_{2} \mathrm{O}}}{\mathrm{LW}}=\frac{\mathrm{b}^{\prime} \mathrm{VWh}}{\mathrm{vnLW}_{1}} .
\end{gathered}
$$

Humidity in Equilibrium With the

Electrolyte $\left(\mathrm{h}_{\mathrm{m}}\right)$

The weight fractions, $\mathbf{x}$, are approximately equal to humidities, $h$, within about 1.5 percent so the substitution of humidities can be made in (C78). Combining (C77) and (C78) and equating to (C79):

$$
\frac{\mathrm{bVWh}_{1}}{\mathrm{vnLW}}=\frac{2 \mathrm{bV}}{3 L \mathrm{v}}\left(\frac{\mathrm{h}_{1}+\mathrm{h}_{2}}{2}-\mathrm{h}_{\mathrm{m}}\right) \text {. }
$$


Equation (C80) reduces to

$$
\frac{h_{1}}{n}=\frac{2}{3}\left(\frac{h_{1}+h_{2}}{2}-h_{m}\right),
$$

and solving for $\mathrm{h}_{\mathrm{m}}$

$$
h_{m}=\frac{h_{1}+h_{2}}{2}-\frac{3 h_{1}}{2 n} \text {. }
$$

Since

$$
\frac{h_{1}+h_{2}}{2}=h_{1}-\frac{h_{1}-h_{2}}{2}
$$

and

$$
h_{1}-h_{2}=\frac{h_{1}}{n},
$$

substituting (C84) in (C83) and then in (C82)

$$
h_{m}=h_{1}-\frac{h_{1}}{2 n}-\frac{3 h_{1}}{2 n}
$$

which simplifies to

$$
\mathrm{h}_{\mathrm{m}}=\mathrm{h}_{1}\left(1-\frac{2}{\mathrm{n}}\right) \text {. }
$$

The value of $\left(\mathrm{h}_{\mathrm{m}}\right)$ from $(\mathrm{C} 86)$ and the value of $\left(\mathrm{T}_{\mathrm{m}}\right)$ from $(\mathrm{C} 61)$ taken together define the average steady-state electrolyte concentration in the matrix at the anode by use of figure 12 .

The driving force $\Delta \mathrm{h}_{\mathrm{m}}$ for mass transfer of water vapor from the air to the matrix from (C80) is

$$
\Delta \mathrm{h}_{\mathrm{m}}=\frac{\mathrm{h}_{1}+\mathrm{h}_{2}}{2}-\mathrm{h}_{\mathrm{m}}
$$

From (C82) it can be seen that

$$
\Delta \mathrm{h}_{\mathrm{m}}=1.5 \frac{\mathrm{h}_{1}}{\mathrm{n}} .
$$


As a first approximation it can be assumed that the same driving force $\Delta \mathrm{h}_{\mathrm{m}}$ exists at all points.along the air flow channel from inlet to outlet. Therefore, the value of $h^{\prime} 1$ (near the inlet) and $h^{\prime} 2$ (near the outlet) are

$$
\begin{aligned}
& h^{\prime}{ }_{1}=h_{1}-1.5 \frac{h_{1}}{n} \\
& h^{\prime}{ }_{2}=h_{2}-1.5 \frac{h_{1}}{n} .
\end{aligned}
$$

Correction for Humidity of Hydrogen

Equation (C2) was only an approximation of (C1) because the water leaving the cell with the hydrogen gas $\left(h_{h}\right)$ was neglected to simplify the derivations. Because of the low flow of hydrogen gas, it can be assumed that the water-vapor pressure of the hydrogen gas is in equilibrium with the water-vapor pressure of the electrolyte at the cathode/hydrogen interface. The latter electrolyte concentration is approximately equal to the electrolyte concentration at the anode/air interface. Humidities can be calculated from vapor pressure as follows:

$$
\begin{aligned}
& \left(\frac{p}{P-p}\right) \frac{18}{28.8}=h_{m}\left(1 b H_{2} \mathrm{O} / 1 b D A\right)
\end{aligned}
$$

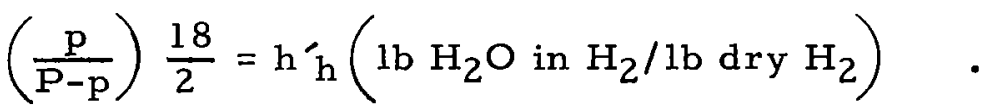

The values of humidity $\left(\mathrm{h}_{\mathrm{m}}\right)$ for figure 12 were calculated from the following form of (C91) using values of water-vapor pressure (p) in equilibrium with phosphoric acid as shown in figure 12. The value of the total pressure (P) was assumed to be $760 \mathrm{~mm} \mathrm{Hg}$ :

$$
\mathrm{p}=\frac{1.6(\mathrm{P})\left(\mathrm{h}_{\mathrm{m}}\right)}{1+1.6\left(\mathrm{~h}_{\mathrm{m}}\right)}
$$

Since electrolysis produces $0.25 \mathrm{lb} \mathrm{H}_{2}$ for each $2.25 \mathrm{lb} \mathrm{H}_{2} \mathrm{O}$ electrolyzed

$$
\mathrm{h}_{\mathrm{h}}^{*}=\left(\frac{\mathrm{p}}{\mathrm{P}-\mathrm{p}}\right) \frac{18}{2}\left(\frac{0.25}{2.25}\right)=\frac{\mathrm{p}}{\mathrm{P}-\mathrm{p}},
$$

where the units of hit are $\mathrm{lb} \mathrm{H}_{2} \mathrm{O}$ in $\mathrm{H}_{2} / 1 \mathrm{~b} \mathrm{H} \mathrm{H}_{2} \mathrm{O}$ electrolyzed. The units of $\left(\mathrm{h}_{\mathrm{e}}\right.$ ) from ( $\mathrm{Cl}$ ) are $1 \mathrm{~b} \mathrm{H}_{2} \mathrm{O}$ electrolyzed/1b DA and combining with (C94) gives $h_{h}$ in units of $1 b \mathrm{H}_{2} \mathrm{O}$ in $\mathrm{H}_{2} / \mathrm{lb}$ DA: 


$$
h_{h}=\frac{p}{P-p}\left(h_{e}\right) \quad \text {. }
$$

Substituting (C91) in (C95):

$$
\begin{gathered}
\mathrm{h}_{\mathrm{h}}=1.6\left(\mathrm{~h}_{\mathrm{m}}\right)\left(\mathrm{h}_{\mathrm{e}}\right) \\
\frac{\mathrm{h}_{\mathrm{h}}}{\mathrm{h}_{\mathrm{e}}}=1.6\left(\mathrm{~h}_{\mathrm{m}}\right)
\end{gathered}
$$

For typical values of $\left(\mathrm{h}_{\mathrm{m}}\right)$ of 0.006 to $0.0101 \mathrm{~b} \mathrm{H} \mathrm{H}_{2} \mathrm{O} / 1 \mathrm{~b} \mathrm{DA}$ (figure 12), the ratio of $h_{h} / h_{e}$ is very small and the error in neglecting $h_{h}$ as in equation (C2) is only 1 to 1.5 percent.

From (C92), (C95), and (C97),

$$
\mathrm{h}_{\mathrm{h}}^{\prime}=14 \mathrm{~h}_{\mathrm{m}}
$$

Equation (C98) can be used to show that the water content of the hydrogen gas from the vapor cell is relatively low compared to other electrolysis systems that use a more dilute electrolyte of higher vapor pressure. For example at $90 \mathrm{~F}$ and $\mathrm{h}_{\mathrm{m}}=0.00651 \mathrm{~b} \mathrm{H} \mathrm{H}_{2} \mathrm{O} / \mathrm{lb} \mathrm{DA}$ from figure 12

$$
\begin{gathered}
\mathrm{h}_{\mathrm{h}_{\mathrm{h}}^{\prime}}=14(0.0065)=0.09 \mathrm{lb} \mathrm{H}_{2} \mathrm{O} / 1 \mathrm{~b} \mathrm{dry} \mathrm{H} \\
\mathrm{h}^{\prime} \text { saturated at } 90 \mathrm{~F}=\frac{(36)(18)}{(760-36)(2)}=0.45 \mathrm{lb} \mathrm{\textrm {H } _ { 2 }} \mathrm{O} / 1 \mathrm{~b} \mathrm{dry} \mathrm{H}_{2} \\
\text { Relative humidity of } \mathrm{H}_{2} \text { gas }=\frac{0.09(100)}{0.45}=20 \%
\end{gathered}
$$

A low water content of the hydrogen gas (i.e., dewpoint of about 4F) is an advantage for hydrogen use in other subsystems for reduction of carbon dioxide.

As shown by equation (C93) the amount of water that has to be transported across the matrix from anode to cathode $\left(h_{h}\right)$ to equal the water lost with the hydrogen gas is only 1 to 1.5 percent of the water consumed in electrolysis. Thus there would be a neglibible electrolyte concentration gradient required from anode to cathode. More likely the ionic transport 
of water in acid electrolyte would tend to make the concentration of acid lower at the cathode than at the anode. Measurement of the humidity of hydrogen gas evolved from the cell and comparison with the theoretical equation (C88) might be used to estimate the electrolyte concentration at the cathode. 
REFERENCES

1. Beach, J. G.; John Clifford, John Gates, and Charles Faust: Research on Solid Phosphorous Pentoxide Electrolytes in Electrolysis Cell for Production of Breathing Oxygen. AMRL-TDR-62-44, May, 1962.

2. Trachtenberg, Isaac: Polarization Studies of Molten Carbonate Fuel Cell Electrodes. J. Electrochem. Soc., vol. III, no. 1, Jan. 1964, pp. $110-113$.

3. Giner, J.: A Practical Reference Electrode. J. Electrochem. Soc., vol. III, no. 3, Mar. 1964, pp. 376-377.

4. Hoare, James P.: The Alpha-Palladium-Hydrogen Electrode. General Motors Engineering Journal, First Quarter 1962, pp. 14-16.

5. Phosphoric Acid. Technical Bulletin 1-239. Monsanto Chemical Co., St. Louis 66, Missouri.

6. Lange, N. A., ed.: Handbook of Chemistry. Tenth ed., McGraw-Hill Book Co., Inc., 1961.

7. Perry, John H., ed.: Chemical Engineers' Handbook. Third ed., McGraw-Hill Book Co., Inc., 1950.

8. Rudek, F. P., and Glanfield, E. J.: A Flight Prototype Water Electrolysis Unit. Preprint 47b, Amer. Inst. Chem. Engr., Feb. 1965.

9. Clifford, J. E., Kolic, E. S., and Faust, C. L.: Research On A Gravity-Independent Water-Electrolysis Cell With A Palladium-Silver Alloy Cathode. AMRL-TDR-64-44, June, 1964.

10. Norris, R. H., and Streid, D. D.: Laminar-Flow Heat Transfer Coefficients for Ducts. Trans. A.S. M.E., vol. 62, 1940, p. 525. 